\title{
Genetic correlation of source rocks and natural gas in the Polish Outer Carpathians and Paleozoic-Mesozoic basement east of Kraków (southern Poland)
}

\author{
Maciej J. KOTARBA ${ }^{1, *}$, Dariusz WIĘCŁAW ${ }^{1}$, Elżbieta BILKIEWICZ ${ }^{1}$, Piotr DZIADZIO² \\ and Adam KOWALSKI ${ }^{1}$ \\ 1 AGH University of Science and Technology, Faculty of Geology, Geophysics and Environmental Protection, \\ al. A. Mickiewicza 30, 30-059 Kraków, Poland \\ 2 Oil and Gas Institute, Lubicz 25a, 31-503 Kraków, Poland
}

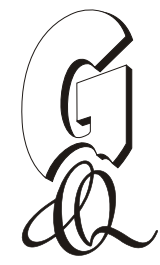

\begin{abstract}
Kotarba, M.J., Wieecław, D., Bilkiewicz, E., Dziadzio, P., Kowalski, A., 2017. Genetic correlation of source rocks and natural gas in the Polish Outer Carpathians and Paleozoic-Mesozoic basement east of Kraków (southern Poland). Geological Quarterly, 61 (4): 795-824, doi: 10.7306/gq.1367

Natural gas-source rock correlations in the Polish Outer Carpathians and Paleozoic-Mesozoic basement in the Kraków-Brzesko-Nowy Sącz area (southern Poland) have been established. In the Dukla and Sub-Silesian units, mixed kerogen Type-II/III or III/II occurs. The organic matter is immature or low-mature. The Oligocene Menilite beds of the Silesian Unit are rich in TOC and contain gas-prone Type III kerogen of low maturity. In the Paleozoic-Mesozoic basement, the TOC content and residual hydrocarbon potential vary in the Middle and Upper Devonian strata, Mississippian carbonate and clastic facies and Middle Jurassic strata. The Paleozoic strata are capable of thermogenic hydrocarbon generation, while organic matter in the Middle Jurassic rocks is generally immature. Gaseous hydrocarbons accumulated both in the Silesian and Dukla units of the Polish Outer Carpathians and in the Mesozoic basement are genetically related to thermogenic and microbial processes. The Outer Carpathian natural gas was generated mainly from the Type-II/III kerogen of the Oligocene Menilite beds. The thermogenic gases from the Mesozoic basement were generated from Devonian and Mississippian (carbonate) Type-II and mixed II/III kerogens and probably from Silurian/Ordovician Type-II kerogen and Middle Jurassic Type-III/II kerogen occurring at more than $7 \mathrm{~km}$ depth. Microbial methane migrated into the Outer Carpathian flysch succession from the Miocene strata of the Carpathian Foredeep.
\end{abstract}

Key words: Polish Outer Carpathians, Paleozoic-Mesozoic basement, source rock potential, natural gas, biomarkers, stable carbon, hydrogen and nitrogen isotopes.

\section{INTRODUCTION}

The Polish Outer Carpathians, Carpathian Foredeep and their Paleozoic-Mesozoic basement constitute the Małopolska Petroleum Province (Karnkowski, 1997, 2007), which is one of the oldest petroleum-producing regions in the world, with the beginning of documented exploitation of oil in 1853 and of natural gas production in 1921 (Karnkowski, 1999; Kotarba and Koltun, 2006). The province is sometimes divided into two sub-provinces. The northern one includes the Carpathian Foredeep Miocene molasse with numerous gas deposits in stratigraphic and structural traps. The southern sub-province includes the Outer Carpathians, in which oil deposits occur in numerous horizons of porous sandstones within the flysch succession. Below the Carpathian Foredeep and Flysch Carpathians, the hydrocarbon accumulations and shows occur

\footnotetext{
* Corresponding author, e-mail: kotarba@agh.edu.pl
}

Received: February 24, 2017; accepted: June 5, 2017; first published online: July 19, 2017 in the Paleozoic-Mesozoic basement in Cambrian, Devonian, Mississippian, Pennsylvanian, Triassic, Upper Jurassic and Upper Cretaceous strata.

The Kraków-Brzesko-Nowy Sącz study area covers over $\sim 600 \mathrm{~km}^{2}$ (Fig. 1). Petroleum (oil and gas) accumulations have been encountered in sandstone reservoirs in almost all stratigraphic-facies members of the Outer Carpathians and in the Devonian, Mississippian and Upper Jurassic carbonates and Upper Cretaceous sandstones of the Paleozoic-Mesozoic basement. The natural gas occurs in the reservoirs both as associated and non-associated accumulations which have distinct geochemical signatures that indicate a range of genetic and post-accumulation histories.

Previous work indicated that associated and non-associated gases accumulated within the strata of the Polish Outer Carpathians and their Paleozoic-Mesozoic basement are mainly low-temperature ("oil window") thermogenic gases and only locally occur either as microbial or as high-temperature ("gas window") thermogenic hydrocarbons (Kotarba, 1987, 1992, 1998a, b; Kotarba and Koltun, 2006; Kotarba et al., 2007, $2013,2014)$. Locations of the study areas discussed in the papers mentioned are shown in Figure 2.

The clayey and siliceous Oligocene Menilite beds are considered to be the primary petroleum source rock of the 


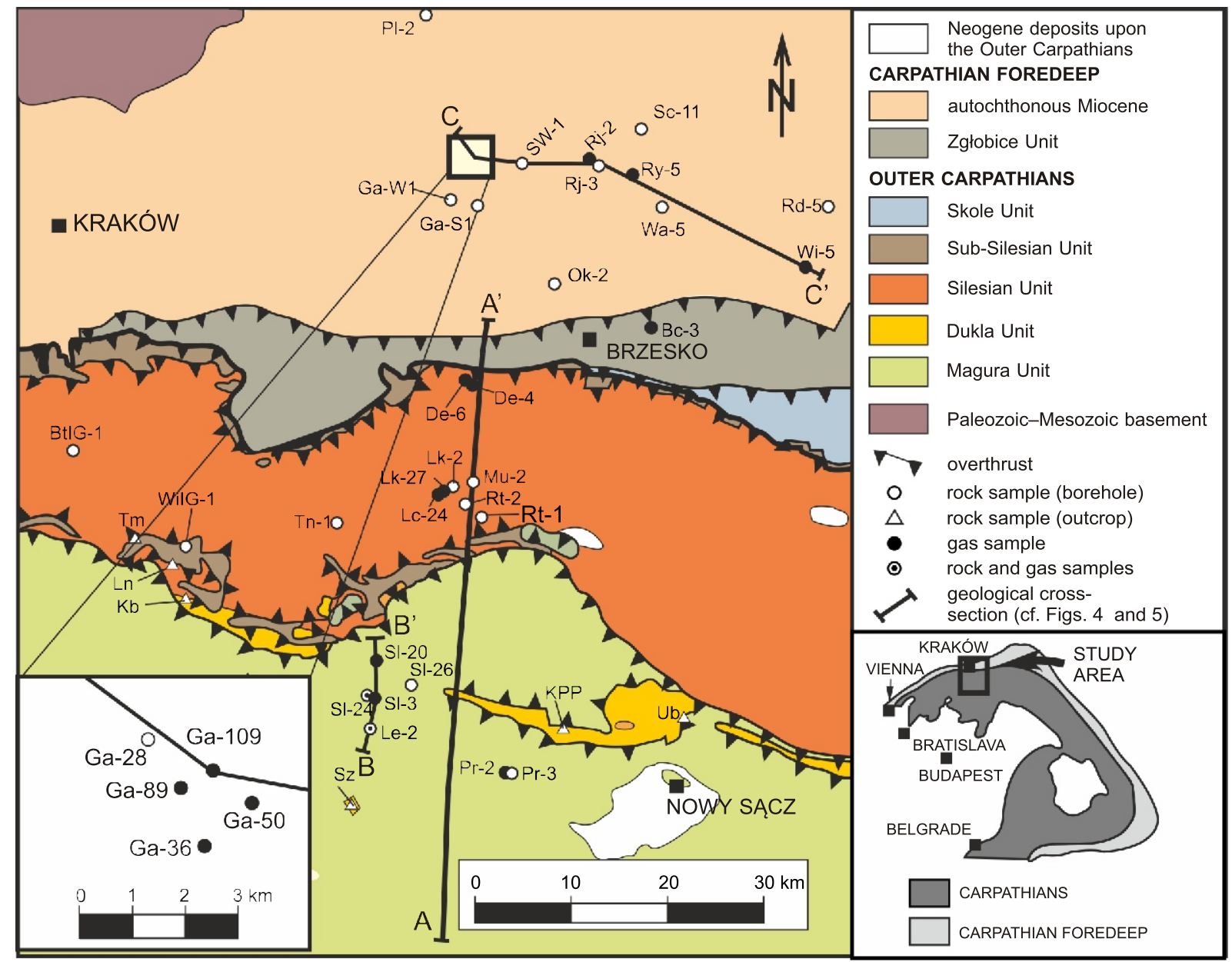

Fig. 1. Geological sketch map of the study area

Geology modified after Książkiewicz (1977), Oszczypko (2006) and Żelaźniewicz et al. (2011) showing the location of tectonic units, rock and gas sampling sites and geological cross-sections (cf. Figs. 4 and 5); borehole codes (rock samples): BtIG-1 Borzęta IG 1; Ga-28 - Grobla-28; Ga-S1 - Grobla-S1, Ga-W1 - Grobla-W1, Lk-2 - Łąkta-2, Mu-2 - Muchówka-2, Ok-2 Okulice-2, PI-2 - Pławowice-2, Pr-3 - Przyszowa-3, Rd-5 - Radlna-5, Rt-1 - Rajbrot-1, Rt-2 - Rajbrot-2, SI-26 - Słopnice-26, Sc-11 - Szczurowa-11, Tn-1 - Tarnawa-1, Wa-5 - Waryś-5, WilG-1 - Wiśniowa IG 1; borehole codes (gas samples): Bc-3 Brzezowiec-3, De-4 - Dołuszyce-4, De-6 - Dołuszyce-6, Ga-36 - Grobla-36, Ga-50 - Grobla-50, Ga-89 - Grobla-89, Ga-109 Grobla-109, Lc-24 - Leszczyna-24, Lk-27 - Łąkta-27, Pr-2 - Przyszowa-2, Rj-2 - Rajsko-2, Rj-3 - Rajsko-3, Ry-5 - Rylowa-5, SI-3 - Słopnice-3, SI-20 - Słopnice-20, Wi-5 - Wierzchosławice-5; borehole codes (rock and gas samples): Le-2 - Leśniówka-2, SI-24 - Słopnice-24; outcrop codes (rock samples): Kb - Kobielnik, KPP - Krasne Potockie-Poddziele, Ln - Lipnik, Sz Szczawa, Tm - Trzemeśnia, Ub - Ubiad

Carpathian deposits with total organic carbon (TOC) exceeding 20 wt.\% (ten Haven et al., 1993; Bessereau et al., 1996; Kotarba and Koltun, 2006; Kotarba et al., 2007). The high petroleum potential of the Menilite beds was shown also by Koltun (1992), Kruge et al. (1996), Koltun et al. (1998), Köster et al. (1998) and Kosakowski et al. (2009). Moreover, previous organic geochemical studies (Kotarba and Koltun, 2006; Kosakowski et al. 2009; Kotarba et al., 2013, 2014) revealed that petroleum source rocks occur also in the following lithostratographic-facies members: black shales of the Lower Cretaceous, Veřovice, Lgota, Gaize, Istebna, Hieroglyphic and Lower Krosno beds (Fig. 3). Więcław et al. (2011) and Kotarba et al. (2011) pointed to Upper Devonian and Mississippian strata in the Upper Paleozoic succession of the Polish Carpathian basement as having the highest petroleum poten- tial, and Kotarba et al. (2003) and Kosakowski et al. (2012a) also identified the Middle Jurassic clays as rocks with the highest hydrocarbon potential among the Mesozoic cover. The location of previous geochemical studies of source rocks in the Polish Outer Carpathians and the Paleozoic-Mesozoic basement (Köster et al., 1998; Kotarba and Koltun, 2006; Kotarba et al., 2007, 2013, 2014; Kosakowski et al., 2012a, b; Wróbel et al., 2016) is shown on Figure 2.

The geochemical characteristics (TOC content, genetic type, maturity and petroleum potential) of the organic matter and the origin of natural gases occurring within the successions of the western part of the Polish Outer Carpathians and Paleozoic-Mesozoic basement in the Kraków-Brzesko-Nowy Sącz area (Fig. 1), as well as the genetic correlation of natural gas and source rocks, are discussed in this paper. 


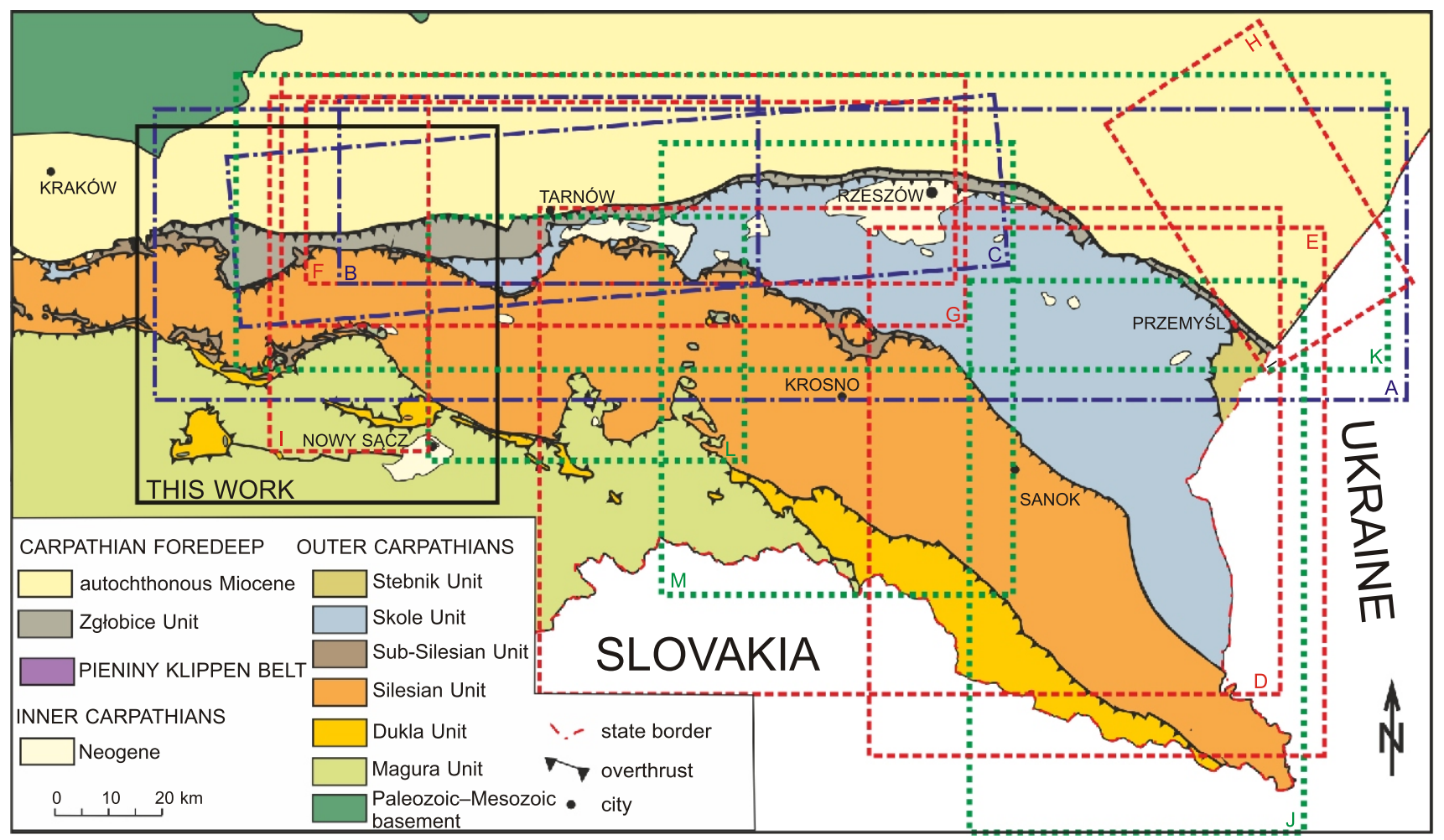

Fig. 2. Location of study areas of the Polish Carpathian Province

Concerning: (i) natural gas (blue dashed-dotted line): A - Kotarba (1987, 1992), B - Kotarba and Jawor (1993), C - Kotarba (2012), (ii) source rocks (red dashed line): D - Köster et al. (1998), E - Kosakowski et al. (2009), F - Więcław et al. (2011), G - Kosakowski et al. (2012a), H - Kosakowski et al. (2012b), I - Wróbel et al. (2016) and (iii) both natural gas and source rocks (green dashed line): J - Kotarba et al. (2007), K - Kotarba et al. (2011), L - Kotarba et al. (2013), M - Kotarba et al. (2014); geology modified after Żelaźniewicz et al. (2011)

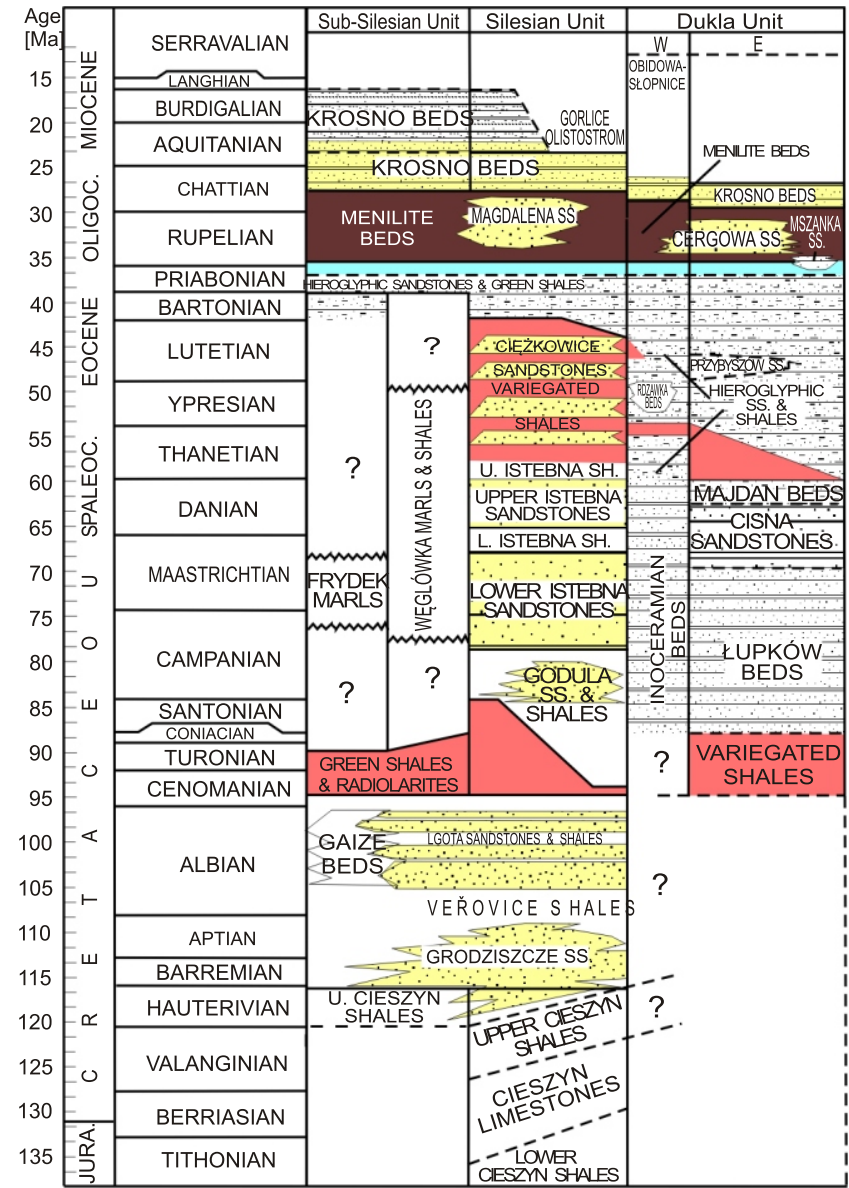

\section{GEOLOGICAL SETTING AND PETROLEUM OCCURRENCE}

The Polish Outer Carpathians are a structurally complex area. The Upper Jurassic to Lower Miocene strata are folded and thrusted northwards in a series of nappes over the autochthonous Miocene molasse (Carpathian Foredeep) and Paleozoic-Mesozoic basement (Żelaźniewicz et al., 2011). A series of imbricate nappe-thrust sheets extends north to northeast over strata of Early Oligocene to Sarmatian (Late Middle Miocene) age. Figure 1 shows the location of major nappes in the study area that are referred to as "units" and named from south to north as the Magura, Dukla, Silesian, Sub-Silesian and Zgłobice units (e.g., Książkiewicz, 1977; Oszczypko, 1997). They have a different tectonic style and lithology by comparison with the eastern part of the Outer Carpathians.

The Dukla Unit in the study area has a different stratigraphic succession than in the eastern part of the Polish Outer Carpathians. The succession starts with the Upper CretaceousPaleogene Inoceramian beds, through Eocene Hieroglyphic

\section{Fig. 3. Simplified lithostratigraphic columns of the Sub-Silesian, Silesian and Dukla units}

North is to the left, modified after Koszarski (1985) and Dziadzio et al. (2006); yellow colour indicates the main hydrocarbon reservoir; pink is main cap rock; blue is Globigerina marls; grey is Menilite beds dominated by shale facies; SH. - shales; SS. - sandstones; L. - Lower; U. - Upper; Jura. - Jurassic; Paleoc. - Paleocene; Oligoc. - Oligocene 

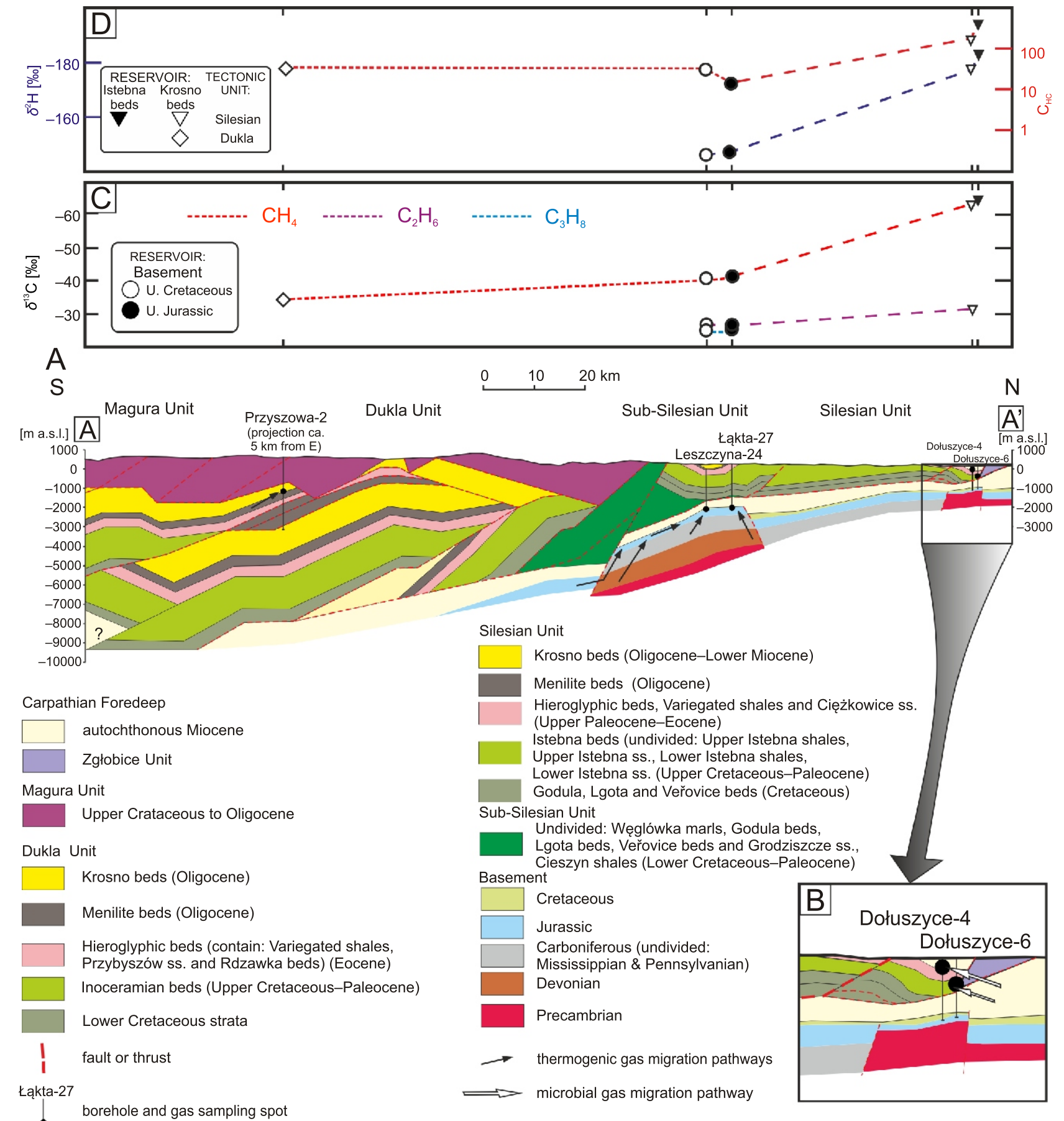

Fig. 4. Przyszowa-Łąkta (A) and Dołuszyce (B) schematic geological cross-sections, distributions of stable carbon isotope composition of methane, ethane and propane $(\mathrm{C})$, and hydrocarbon index $\left(\mathrm{C}_{\mathrm{HC}}\right)$ and stable hydrogen isotope composition of methane (D)

For location see Figure 1; Silesian Unit: Istebna - Upper Cretaceous-Paleocene Istebna beds; Dukla Unit: Inoceramian - Upper Cretaceous Inoceramian beds; Silesian and Dukla units: Krosno - Oligocene-Lower Miocene Krosno beds; Basement: U. - Upper

sandstones and shales (Rdzawka beds) and Eocene-Oligocene Globigerina marls, which are overlain by the Oligocene Menilite beds, Cergowa sandstones, and Krosno beds (Ślączka, 1971, 1996; Koszarski, 1985; Dziadzio et al., 2001; Fig. 3). The Dukla Unit in the western part of the Outer Carpathians is exposed in the form of tectonic windows only. The Menilite beds in tectonic windows of the Dukla Unit are locally named the Sub-Grybów and Grybów beds. The zones of tectonic windows were subjected to multistage development related to the duplex folds formed under the Magura Unit (Figs. 4 and 5). The Oligocene units encountered in the Skrzydlna area are traditionally considered to represent the Menilite and Krosno beds of the conflictingly named tectonic unit which outcrops in the "Mszana Dolna Tectonic Window" at the front of the "Magura Nappe". This tectonic unit is often referred to variously as the "Silesian", "Dukla", "Sub-Magura", "Grybów" or "Obidowa-Słopnice" unit (e.g., Karnkowski, 1999; Starzec et al., 2016; Waśkowska et al., 2016), here interpreted as the Dukla Unit. 

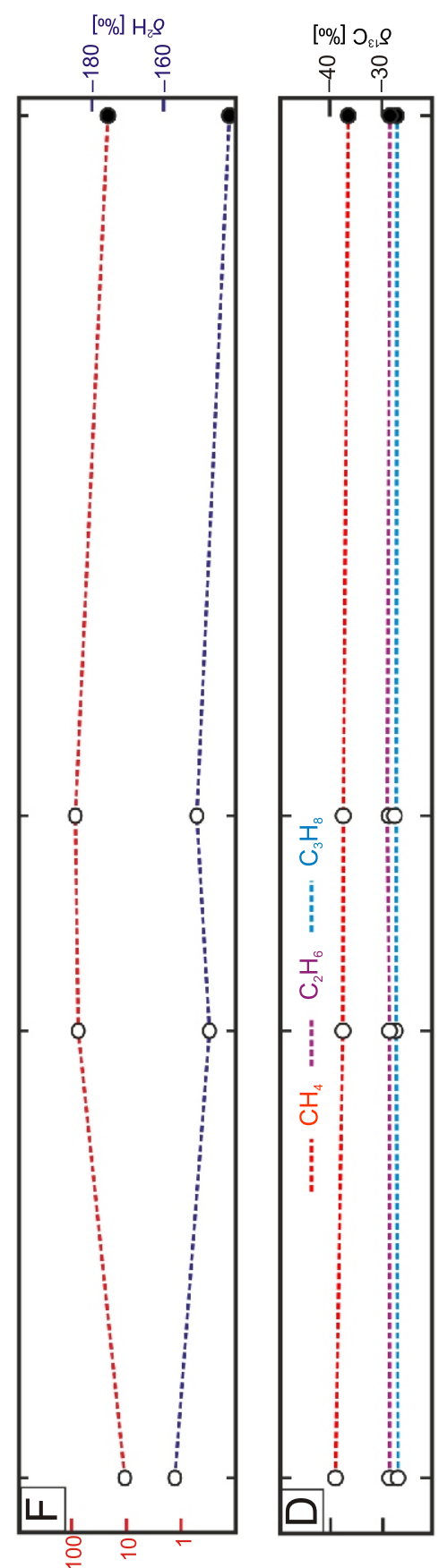

山闭

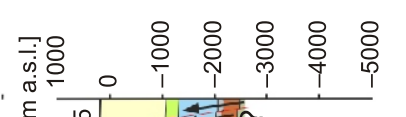

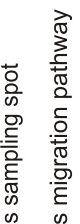

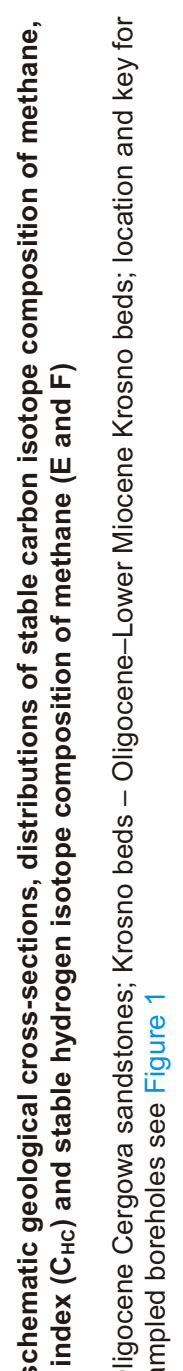
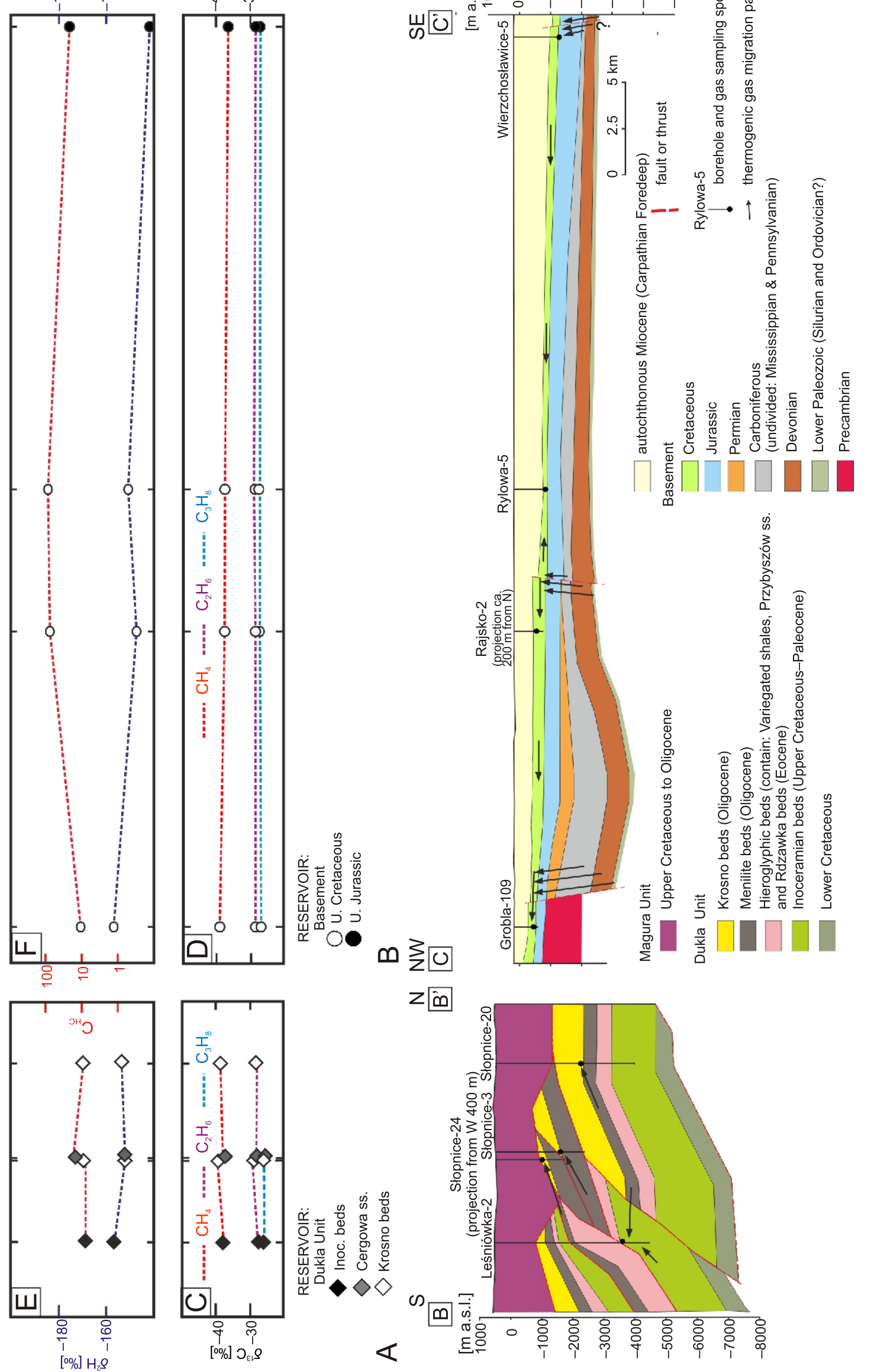

$z \ddot{\omega}$
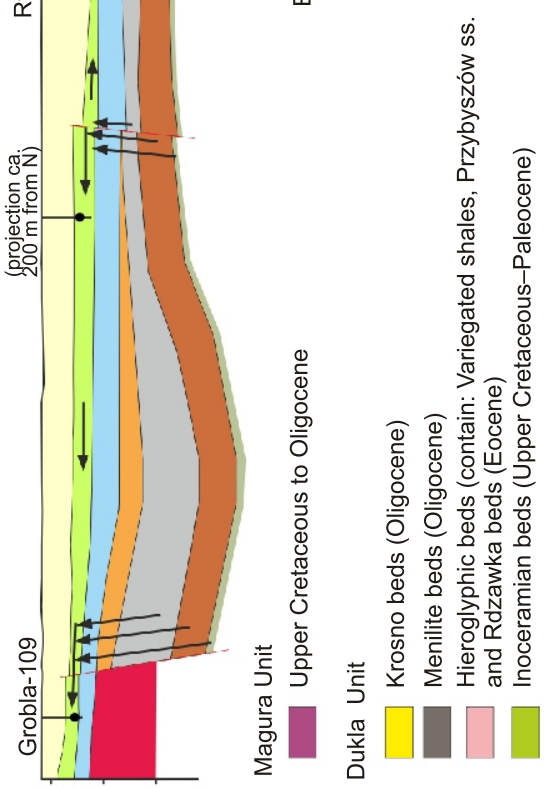

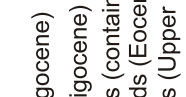

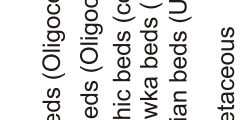

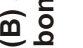

造

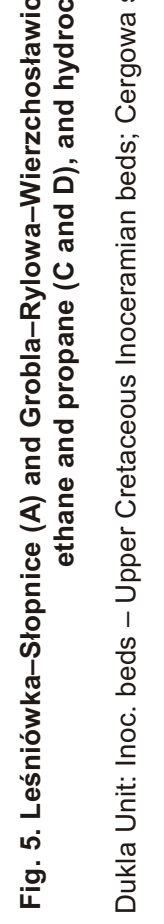

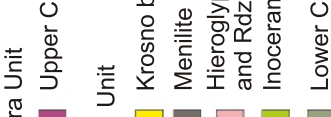

II

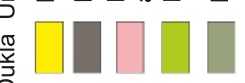


Strongly disturbed tectonic conditions can be also observed in the Sub-Silesian Unit. The successions of this unit of Early Cretaceous to Early Miocene age (Fig. 3) are strongly deformed and thrusted on the Skole Unit and autochthonous Miocene strata of the Carpathian Foredeep.

The Silesian Unit is the best analysed and recognized unit (e.g., Ślączka and Kaminski, 1998; Dziadzio et al., 2006). The formations making up the Silesian Unit are known from all parts of the Western Carpathians. The oldest rocks of the Silesian succession have been found in the western and in the eastern parts, starting with the Upper Jurassic Cieszyn beds (Fig. 3). The Cieszyn beds are overlain by the Verovice beds with the Grodziszcze sandstones and a succession of Lgota and Gaize beds. The Godula beds are a younger succession (Fig. 3). These strata are overlain by the Upper Cretaceous-Paleocene Istebna beds and a succession of Variegated shales with a few intercalations of the Upper Paleocene-Middle Eocene Ciężkowice sandstones. Above this succession, the Upper Eocene Hieroglyphic beds occur over the whole Carpathian area. They successively appear and are followed by the Globigerina marls, which can be observed in all tectonic units of the Carpathians, as well as the Lower Oligocene Menilite beds with local sandstone intercalations. The Oligocene-Lower Miocene Krosno beds (Fig. 3) occur in the uppermost part of the succession and terminate the sedimentation in the Carpathian area.

The Precambrian-Paleozoic basement of the Polish part of the Outer Carpathians and Carpathian Foredeep between Kraków and Brzesko (Fig. 1) is divided into the Małopolska and Upper Silesian blocks (Buła and Habryn, 2011 and references therein). The Małopolska Block and the eastern part of the Upper Silesian Block successions include the Precambrian, Devonian and Mississippian, while the Cambrian, Silurian and Pennsylvanian occur in the neighbourhood (Moryc, 2006a, b, 2014; Buła and Habryn, 2011 and references therein). The Precambrian-Paleozoic basement is overlain by the epi-Variscan Permian-Mesozoic succession of the Cracow-Silesia Monocline (Moryc, 2006a; Żelaźniewicz et al., 2011). The Mesozoic basement in the study area (Fig. 1) consists of three successions represented by (1) a small intercalations of the Permian and/or Triassic clastics and anhydrites (Kiersnowski, 2001; Moryc, 2014), (2) Middle and Upper Jurassic-Lower Cretaceous clastics and carbonates (Moryc, 2006b), and (3) Upper Cretaceous glauconitic sandstones, marls, limestones and gaizes (Karnkowski, 1999; Moryc, 2006b). It is covered by autochthonous Miocene of the Carpathian Foredeep.

Oil and gas accumulations in the study area occur in the Upper Cretaceous and Paleocene (Inoceramian and Istebna beds) and Oligocene (Cergowa sandstones and Krosno beds) strata of the Outer Carpathians (e.g., the Skrzydlna and Słopnice fields, both abandoned), as well as in the Upper Jurassic carbonates and Upper Cretaceous sandstones (Brzezowiec, Grobla-Pławowice, Łąkta and Rylowa fields) of the Mesozoic basement. There are also gas fields in the autochthonous Miocene strata of the Carpathian Foredeep (Kotarba, 2011). The Limanowa-Słopnice oil and gas field is the most important accumulation in the study area. Gas-saturated horizons occur in the Cergowa sandstones and in the lower part of the Krosno beds within the Dukla Unit, which are overthrusted by the Magura Unit. Hydrocarbon accumulation is present within the thrust-related recumbent Słopnice Fold. Also, a small natural gas accumulation occurs in the Krosno and Istebna beds in the Dołuszyce field. In the northern neighbourhood, the Łąkta gas accumulation field occurs in Upper Jurassic carbonates, Upper Cretaceous (Cenomanian) sandstones and Badenian sandstones (autochthonous Miocene).

\section{MATERIAL AND SAMPLING PROCEDURE}

\author{
ROCK SAMPLES
}

The Outer Carpathians. A total of 60 rock samples were collected from the Outer Carpathian flysch succession. Thirty-two samples came from the Dukla Unit, in which 16 were collected from the Leśniówka-2, Przyszowa-3 and Słopnice-26 boreholes, and 16 other samples were derived from the Kobielnik, Krasne Potockie-Poddziele and Ubiad exposures (Fig. 1). Fourteen samples were taken from the Silesian Unit: 12 core samples came from the Borzęta IG 1 borehole and 2 from the Lipnik exposure. Fourteen other samples were collected from the Sub-Silesian Unit, in which: 9 samples were derived from cores from the Wiśniowa IG 1 borehole and another 5 samples were taken from exposures in Lipnik and Trzemeśnia (Fig. 1). Once the outer (up to $35 \mathrm{~cm}$ ) fissile shale layers were removed, fresh slabby to blocky $2 \mathrm{~kg}$ samples with no saprolite rinds were collected at exposures according to sampling criteria described by Lewan (1980).

Moreover, for genetic interpretation we also used the previous results of Rock-Eval-II pyrolysis analyses of 81 samples from the Leśniówka-2, Słopnice-24 and -26, Muchówka-2 and Rajbrot-1 boreholes (Kotarba and Koltun, 2006) and 4 samples from the Szczawa exposure (Więcław, 2002). In total, we used the results of 141 Rock-Eval pyrolysis measurements for geochemical characteristics of the flysch strata. The detailed quantities of samples collected from individual lithostratigraphic units are given in Table 1 (the Dukla Unit) and Table 2 (the Sub-Silesian and Silesian units).

The Paleozoic-Mesozoic basement. In total, 88 core samples were collected from the Paleozoic-Mesozoic basement. The geochemical characteristics of the Paleozoic succession were described based on investigations of 79 samples of Lower Devonian and Mississippian age. The Devonian samples came from the Grobla-28, Okulice-2, Radłów-5, Rajbrot-1, Rajsko-3, Szczurowa-11 and Waryś-5 boreholes. The Mississippian strata were sampled from the Łąkta-2, Rajbrot-1 and Strzelce Wielkie-1 boreholes (Fig. 1). Nine samples were collected from the Middle Jurassic strata of the Mesozoic basement in the Borzęta IG 1 and Tarnawa-1 boreholes (Fig. 1).

For genetic interpretation we also used the previous results of Rock-Eval-Il pyrolysis analyses of 30 Devonian samples from the Grobla-28, Rajbrot-1 and -2, Rajsko-3 and Waryś-5 boreholes (Więcław et al., 2011; Wróbel et al., 2016), 59 Mississippian samples from the Łąkta-2, Rajbrot-1, -2 and Strzelce Wielkie-1 boreholes (Matyasik et al., 2001; Kotarba et al., 2004a, b), 17 Middle Jurassic samples from the Tarnawa-1 and Strzelce Wielkie-1 (Kotarba et al., 2003) and 25 Upper Jurassic samples from Upper Jurassic strata collected from the Grobla-S1, Grobla-W1, Pławowice-2 and Rajbrot-1 boreholes (Kosakowski et al., 2012a). In total, we used the results of 219 Rock-Eval pyrolysis measurements for geochemical characteristics of the Paleozoic-Mesozoic basement. The detailed quantities of the samples collected from individual stratigraphic units are given in Table 3 .

One natural gas sample was collected from the flysch succession of the Outer Carpathians. The sample is derived from the Leśniówka-2 (Le-2) borehole, from the sandstone reservoir developed in the Upper Cretaceous-Paleocene Ropa beds in the Dukla Unit. Moreover, three natural gas samples were collected from the Grobla-50 (Ga-50), Rajsko-2 (Rj-2) and Rylowa-5 (Ry-5) boreholes, from sandstone reservoirs developed in the Upper Cretaceous in the Mesozoic basement. 
Geochemical characteristics and hydrocarbon potential of individual lithostratigraphic units within the Dukla Unit

\begin{tabular}{|c|c|c|c|c|}
\hline Beds & Inoceramian & $\begin{array}{l}\text { Hieroglyphic ss. \& sh. } \\
\text { (Rdzawka beds) }\end{array}$ & Menilite & Krosno \\
\hline Stratigraphy & Upper Cretaceous & Eocene & Oligocene & Oligocene \\
\hline \multirow{2}{*}{$\begin{array}{c}\text { Total organic } \\
\text { carbon (TOC) } \\
{[w t . \%]}\end{array}$} & 0.31 to 0.50 & $\underline{0.02 \text { to } 1.73(8)}$ & 0.20 to $8.2(43,14)$ & 0.09 to $0.96(20,2)$ \\
\hline & 0.37 & 0.43 & $0.68 \quad(4,3)$ & $0.47 \quad(4,1)$ \\
\hline \multirow{2}{*}{$T_{\max }\left[{ }^{\circ} \mathrm{C}\right]$} & 456 to 458 & \multirow{2}{*}{$\frac{451 \text { to } 456}{454}(6)$} & 436 to 580 & 441 to 487 \\
\hline & 457 & & 460 & 457 \\
\hline \multirow{2}{*}{$\begin{array}{c}S_{2} \\
\text { [mg HC/g rock] }\end{array}$} & 0.12 to 0.42 & 0.15 to 1.83 & 0.05 to 31.0 & 0.10 to 2.10 \\
\hline & 0.21 & 0.54 & 0.27 & 0.27 \\
\hline \multirow{2}{*}{$\begin{array}{l}\text { Production } \\
\text { index (PI) }\end{array}$} & 0.14 to 0.43 & 0.14 to 0.35 (6) & 0.02 to 0.46 & 0.21 to 0.49 (22) \\
\hline & 0.19 & 0.25 & 0.34 & 0.33 \\
\hline \multirow{2}{*}{$\begin{array}{c}\text { Hydrogen } \\
\text { index (HI) } \\
{[\text { mg HC/g TOC] }}\end{array}$} & 32 to 84 & 44 to 150 & 7 to 507 & \multirow{2}{*}{$\frac{37 \text { to } 239}{65}$ (22) } \\
\hline & 67 & 89 & 41 & \\
\hline \multirow{2}{*}{$\begin{array}{c}\text { Oxygen index } \\
(\mathrm{OI}) \\
{\left[\mathrm{mg} \mathrm{CO}_{2} / \mathrm{g} \text { TOC] }\right.}\end{array}$} & 8 to 20 & \multirow{2}{*}{0 to 68 (6) } & 0 to 80 & \multirow{2}{*}{$\frac{6 \text { to } 122}{27} \quad$ (22) } \\
\hline & 19 & & 12 & \\
\hline $\begin{array}{l}\text { Type of } \\
\text { kerogen }\end{array}$ & $\begin{array}{l}\text { III/II (II/III) } \\
\text { gas-prone } \\
\text { (oil-prone) }\end{array}$ & $\begin{array}{c}\text { II (II/III) } \\
\text { (oil and gas-prone) }\end{array}$ & $\begin{array}{l}\text { II/III (II) } \\
\text { oil-prone }\end{array}$ & $\begin{array}{l}\text { II/III and III/II } \\
\text { gas- and/or } \\
\text { oil-prone }\end{array}$ \\
\hline Maturity & mature & mature & $\begin{array}{l}\text { mature and } \\
\text { overmature }\end{array}$ & $\begin{array}{l}\text { mature and } \\
\text { overmature }\end{array}$ \\
\hline $\begin{array}{l}\text { Hydrocarbon } \\
\text { potential }\end{array}$ & poor & $\begin{array}{l}\text { poor or } \\
\text { moderate }\end{array}$ & $\begin{array}{c}\text { poor-moderate- } \\
\text {-good }\end{array}$ & poor \\
\hline
\end{tabular}

$T_{\max }$ - temperature of maximum of $S_{2}$ peak; $S_{2}$ - residual petroleum potential, ss. - sandstones; sh. - shales; geochemical parameters and indices are given as numerators of minimum and maximum values, in denominator median values, and parenthesized (numerator of number of samples from boreholes, italicized - from outcrops, number of sampled boreholes in denominator and italicized number of sampled outcrops); kerogen type in parenthesis secondary occurrence

All natural gas samples were taken from the producing wells. Free gases (Le-2, Rj-2 and Ry-5) were collected directly at the well head, and gas dissolved in oil (Ga-50) from the separator. The general information on the location of sampling sites is given in Appendix $1^{*}$ and Figure 1.

The results of the previous investigations on molecular and isotopic compositions of the natural gas were also used for genetic interpretation (Kotarba, 1987, 1992, 2012; Kotarba and Jawor, 1993; Kotarba and Nagao, 2008; Kotarba et al., 2009). These included six natural gas samples collected from the Upper Cretaceous-Miocene flysch of the Outer Carpathians, in which two gas samples were collected from the Dołuszyce-4 (De-4) and Dołuszyce-6 (De-6) boreholes in the Silesian Unit, and four gas samples derived from the Przyszowa-2 (Pr-2), Słopnice-3 (SI-3), Słopnice-20 (SI-20) and Słopnice-24 (SI-24) boreholes in Dukla Unit (Fig. 1). Seven other natural gas samples were collected from the Mesozoic basement, in which four samples came from the Brzezowiec-3 (Bc-3), Grobla-89
(Ga-89), Grobla-109 (Ga-109) and Leszczyna-24 (Lc-24) boreholes from the Upper Cretaceous sandstones, and three samples were taken from the Grobla-36 (Ga-36), Łąkta-27 (Lk-27) and Wierzchosławice-5 (Wi-5) boreholes from the Upper Jurassic carbonate reservoirs (Fig. 1).

\section{ANALYTICAL PROCEDURE}

Rock samples. Screening pyrolysis analyses of rock samples were carried out with Rock-Eval Model II apparatus (only selected samples using Rock-Eval 6 Turbo) equipped with an organic carbon module. Aliquots of the pulverised samples were extracted with dichloromethane:methanol (93:7 v/v) using SOXTEC ${ }^{\mathrm{TM}}$ apparatus. The asphaltene fraction was precipitated from bitumen with $n$-hexane. Then, the remaining maltenes were separated into compositional fractions of saturated hydrocarbons, aromatic hydrocarbons and resins by col- 
Geochemical characteristics and hydrocarbon potential of individual lithostratigraphic units within the Sub-Silesian and Silesian units

\begin{tabular}{|c|c|c|c|c|c|c|}
\hline Unit & \multicolumn{2}{|c|}{ Sub-Silesian } & \multicolumn{4}{|c|}{ Silesian } \\
\hline Beds & Upper Cieszyn & Grodziszcze* & Lgota & Godula & Istebna & Menilite \\
\hline Stratigraphy & Lower Cretaceous & Lower Cretaceous & Lower Cretaceous & Upper Cretaceous & $\begin{array}{c}\text { Upper Cretaceous- } \\
\text { Paleocene }\end{array}$ & Oligocene \\
\hline Total organic & 0.79 to $1.63(5,3)$ & 0.19 to $1.38(4,2)$ & 0.01 to $1.22(15)$ & 0.00 to $0.48(11)$ & 0.19 to $1.97(7)$ & (2) \\
\hline [wt.\%] & $1.07 \quad(1,2)$ & $0.94 \quad(1,1)$ & 0.15 & $0.09 \quad \overline{(2)}$ & $1.05 \quad(1)$ & 2.0 and $7.2 \overline{(1)}$ \\
\hline$T_{\max }\left[{ }^{\circ} \mathrm{C}\right]$ & $\frac{425 \text { to } 438}{437}$ & $\frac{424 \text { to } 438}{437}$ & $\frac{427 \text { to } 433}{429}$ & 437 & $\frac{431 \text { to } 435}{433}$ (6) & 428 and 436 \\
\hline$\frac{S_{2}}{[\mathrm{mg} \mathrm{HC} / \mathrm{g} \text { rock] }}$ & $\frac{0.50 \text { to } 2.23}{1.60}$ & $\frac{0.16 \text { to } 2.37}{1.43}$ & $\frac{0.14 \text { to } 1.04}{0.47}$ (6) & 0.25 & $\frac{0.38 \text { to } 0.89}{0.84}(6)$ & 2.5 and 7.8 \\
\hline $\begin{array}{l}\text { Production } \\
\text { index }(\mathrm{PI})\end{array}$ & $\frac{0.06 \text { to } 0.11}{0.07}$ & $\frac{0.04 \text { to } 0.06}{0.06}$ & $\frac{0.02 \text { to } 0.16}{0.11}$ & 0.14 & $\frac{0.01 \text { to } 0.06}{0.04}(6)$ & 0.02 and 0.03 \\
\hline $\begin{array}{c}\text { Hydrogen } \\
\text { index (HI) } \\
{[\mathrm{mg} \mathrm{HC} / \mathrm{g} \mathrm{TOC}]}\end{array}$ & $\frac{57 \text { to } 230}{140}$ & $\frac{59 \text { to } 231}{151}$ & $\frac{38 \text { to } 153}{102}$ & 52 & $\frac{36 \text { to } 127}{52}$ & 109 and 126 \\
\hline $\begin{array}{c}\text { Oxygen index } \\
(\mathrm{OI}) \\
\left(\mathrm{mg} \mathrm{CO}_{2} / \mathrm{g} \text { TOC) }\right.\end{array}$ & $\frac{6 \text { to } 36}{22}$ (8) & $\frac{14 \text { to } 200}{21}$ (6) & $\frac{25 \text { to } 100}{76}$ & 35 & $\frac{16 \text { to } 51}{32}$ & 2 and 9 \\
\hline $\begin{array}{l}\text { Type of } \\
\text { kerogen }\end{array}$ & $\begin{array}{l}\text { III (III/II) } \\
\text { gas-prone }\end{array}$ & $\begin{array}{l}\mathrm{III} / \mathrm{II} \text { and II/III } \\
\text { gas- and/or } \\
\text { oil-prone }\end{array}$ & $\begin{array}{c}\text { III } \\
\text { gas-prone }\end{array}$ & $?$ & $\begin{array}{c}\text { III (III/II) } \\
\text { gas-prone } \\
\text { (oil-prone spor.) }\end{array}$ & $\begin{array}{c}\text { III } \\
\text { gas-prone }\end{array}$ \\
\hline Maturity & $\begin{array}{l}\text { immature and } \\
\text { low-mature }\end{array}$ & $\begin{array}{l}\text { immature and } \\
\text { low-mature }\end{array}$ & $\begin{array}{l}\text { immature and } \\
\text { low-mature }\end{array}$ & low-mature & low-mature & $\begin{array}{l}\text { immature and } \\
\text { low-mature }\end{array}$ \\
\hline $\begin{array}{l}\text { Hydrocarbon } \\
\text { potential }\end{array}$ & $\begin{array}{c}\text { poor } \\
\text { or moderate }\end{array}$ & $\begin{array}{l}\text { poor or } \\
\text { moderate }\end{array}$ & poor & lean & poor & good \\
\hline
\end{tabular}

* claystone intercalations within Grodziszcze sandstones; other explanations as in Table 1

umn chromatography, using alumina/silica gel $(2: 1 \mathrm{v} / \mathrm{v})$ columns $(0.8 \times 25 \mathrm{~cm})$. The fractions were eluted with $n$-hexane, toluene, and toluene:methanol $(1: 1 \mathrm{v} / \mathrm{v})$, respectively.

After removing carbonates with hydrochloric acid and extraction of bitumen, rock samples selected for stable carbon isotope analysis of kerogen were combusted in an on-line system. The extracted bitumen and their fractions (saturated hydrocarbons, aromatic hydrocarbons, resins and asphaltenes) were prepared by the same procedure for stable carbon isotope analyses. Stable carbon isotope analyses were performed using the Finnigan Delta Plus mass spectrometer. The stable carbon isotope data are shown in the $\delta$-notation relative to VPDB standard, with an analytical precision estimated to be $\pm 0.2 \%$. The isolation of kerogen and its elemental analysis procedure was described by Więcław et al. (2012a).

Gas chromatographic separations of the $\mathrm{C}_{11+}$ saturated hydrocarbons (including $n$-alkanes and isoprenoids) were performed on a Hewlett Packard 5890 Series // GC equipped with flame ionization (FID) and a $50 \mathrm{~m} \times 0.1 \mathrm{~mm} \times 0.5 \mu \mathrm{m}$ DB-1 capillary column coated with methyl silicon gum phase, temperature-programmed from $30^{\circ} \mathrm{C}$ held for $5 \mathrm{~min}$., then increased to $320^{\circ} \mathrm{C}$ at the rate $3^{\circ} \mathrm{C} / \mathrm{min}$. and at final temperature held for $20 \mathrm{~min}$. Nitrogen was used as a carrier gas.

The saturated and aromatic hydrocarbon fractions isolated from the bitumen were analysed by the GC-MS for biomarker determination. The analysis was carried out with the Agilent $7890 \mathrm{~A}$ gas chromatograph equipped with the Agilent $7683 \mathrm{~B}$ au- tomatic sampler, an on-column injection chamber and a fused silica capillary column $(60 \mathrm{~m} \times 0.25 \mathrm{~mm}$ i.d. $)$ coated with $95 \%$ methyl-/5\% phenylsiloxane phase (DB-5MS, $0.25 \mu \mathrm{m}$ film thickness). Helium was used as a carrier gas. The GC oven was programmed: $80^{\circ} \mathrm{C}$ held for $1 \mathrm{~min}$., next increased to $120^{\circ} \mathrm{C}$ at the rate of $20^{\circ} \mathrm{C} / \mathrm{min}$., then increased further to $300^{\circ} \mathrm{C}$ at a rate of $3^{\circ} \mathrm{C} / \mathrm{min}$. and at final temperature held for $35 \mathrm{~min}$. The gas chromatograph was coupled with a $5975 \mathrm{C}$ mass selective detector (MSD). The MS was operated with an ion source temperature of $230^{\circ} \mathrm{C}$, ionisation energy of $70 \mathrm{eV}$ and a cycle time of 1 second in the mass range from 45 to 500 Daltons. In the selected ion mode (SIM) the dwell time of the operated MSD was set to 30 milliseconds for each ion.

The aromatic hydrocarbon fractions of oils were analysed by GC for phenanthrene, dibenzothiophene and their methyl derivative relative concentrations with the use of an Agilent $7890 \mathrm{~A}$ gas chromatograph equipped with fused silica capillary column (60 m $\times 0.32 \mathrm{~mm}$ i.d.) coated with $95 \%$ methyl $/ 5 \%$ phenylsilicone phase (DB-5MS, $0.25 \mu \mathrm{m}$ film thickness). Helium was used as a carrier gas. The GC oven was programmed from 40 to $300^{\circ} \mathrm{C}$ at a rate of $3^{\circ} \mathrm{C} / \mathrm{min}$. The gas chromatograph was coupled with a $5975 \mathrm{C}$ inert mass selective detector (MSD). The MS was operated with an ion source temperature of $200^{\circ} \mathrm{C}$, ionisation energy of $70 \mathrm{eV}$ and a cycle time of $1 \mathrm{~s}$ in the mass range from 40 to 600 Daltons.

Measurements of the mean random reflectance of vitrinite $\left(R_{r}\right)$ were carried out with a Zeiss-Opton microphotometer at 
Geochemical characteristics and hydrocarbon potential of Paleozoic-Mesozoic complex

\begin{tabular}{|c|c|c|c|c|c|c|}
\hline Stratigraphy & Lower Devonian & $\begin{array}{l}\text { Middle and Upper } \\
\text { Devonian }\end{array}$ & $\begin{array}{c}\text { Mississippian } \\
\text { (carbonate) }\end{array}$ & $\begin{array}{l}\text { Mississippian } \\
\text { (clastic) }\end{array}$ & Middle Jurassic & Upper Jurassic \\
\hline \multirow{2}{*}{$\begin{array}{c}\text { Total organic } \\
\text { carbon (TOC) } \\
{[w t . \%]}\end{array}$} & 0.01 to $0.18 \quad(11)$ & 0.00 to 2.6 & 0.01 to 5.0 (51) & 0.03 to 2.8 (19) & 0.00 to $15.7(26)$ & 0.00 to 0.39 (25) \\
\hline & 0.02 & $0.20 \quad(6)$ & 0.29 & $1.05 \quad(1)$ & 6.5 & 0.08 \\
\hline$T_{\max }\left[{ }^{\circ} \mathrm{C}\right]$ & - & $\frac{428 \text { to } 466}{438}(12)$ & $\frac{416 \text { to } 468}{430}(20)$ & $\frac{432 \text { to } 451}{441}$ (14) & $\frac{407 \text { to } 430}{421}$ (22) & $\frac{420 \text { to } 428}{423}$ (4) \\
\hline $\begin{array}{c}\mathrm{S}_{2} \\
\text { [mg HC/g rock] }\end{array}$ & - & $\frac{0.00 \text { to } 7.4}{0.04}(45)$ & $\frac{0.13 \text { to } 13.7}{1.05}$ (26) & $\frac{0.33 \text { to } 3.0}{0.82}(14)$ & $\frac{0.22 \text { to } 43.1}{22.7}(22)$ & $\frac{0.19 \text { to } 0.53}{0.31}(4)$ \\
\hline $\begin{array}{l}\text { Production } \\
\text { index }(\mathrm{PI})\end{array}$ & - & $\frac{0.01 \text { to } 1.00}{0.69}(45)$ & $\frac{0.01 \text { to } 0.62}{0.05}$ (26) & $\frac{0.03 \text { to } 0.32}{0.20}(14)$ & $\frac{0.02 \text { to } 0.27}{0.03}(22)$ & $\frac{0.14 \text { to } 0.18}{0.16}$ (4) \\
\hline $\begin{array}{c}\text { Hydrogen } \\
\text { index (HI) } \\
\text { [mg HC/g TOC] }\end{array}$ & - & $\frac{0 \text { to } 367}{7}$ (45) & $\frac{37 \text { to } 361}{230}$ (26) & $\frac{47 \text { to } 116}{58}(14)$ & $\frac{62 \text { to } 467}{264}(22)$ & $\frac{77 \text { to } 166}{105}$ (4) \\
\hline $\begin{array}{c}\text { Oxygen index } \\
(\mathrm{OI}) \\
{\left[\mathrm{mg} \mathrm{CO}_{2} / \mathrm{g} \mathrm{TOC}\right]}\end{array}$ & - & $\frac{10 \text { to } 219}{83}(45)$ & $\frac{14 \text { to } 130}{33}$ (26) & $\frac{7 \text { to } 73}{28}(14)$ & $\frac{3 \text { to } 121}{10}(22)$ & $\frac{72 \text { to } 105}{93}$ (4) \\
\hline $\begin{array}{l}\text { Type of } \\
\text { kerogen }\end{array}$ & ? & $\begin{array}{c}\text { II } \\
\text { oil-prone }\end{array}$ & $\begin{array}{c}\text { II (II/III) } \\
\text { oil-prone } \\
\text { (gas-prone) }\end{array}$ & $\begin{array}{l}\text { III (III/II) } \\
\text { gas-prone } \\
\text { (oil-prone) }\end{array}$ & $\begin{array}{l}\text { III (III/II) } \\
\text { gas-prone } \\
\text { (oil-prone) }\end{array}$ & $\begin{array}{c}\text { III } \\
\text { gas-prone }\end{array}$ \\
\hline Maturity & $?$ & mature & $\begin{array}{l}\text { immature and } \\
\text { mature }\end{array}$ & mature & immature & immature \\
\hline $\begin{array}{l}\text { Hydrocarbon } \\
\text { potential }\end{array}$ & lean & poor & $\begin{array}{l}\text { poor or } \\
\text { moderate }\end{array}$ & $\begin{array}{l}\text { poor or } \\
\text { moderate }\end{array}$ & $\begin{array}{l}\text { very } \\
\text { good }\end{array}$ & lean \\
\hline
\end{tabular}

Explanations as in Table 1

$546 \mathrm{~nm}$ wavelength, in oil. Sample preparation and point counts were carried out in accordance with the International Committee for Coal and Organic Petrology (ICCP) procedure (Taylor et al., 1998).

Natural gas samples. Molecular compositions of natural gases $\left(\mathrm{CH}_{4}, \mathrm{C}_{2} \mathrm{H}_{6}, \mathrm{C}_{3} \mathrm{H}_{8}, i \mathrm{C}_{4} \mathrm{H}_{10}, n \mathrm{C}_{4} \mathrm{H}_{10}, \mathrm{C}_{5} \mathrm{H}_{12}, \mathrm{C}_{6} \mathrm{H}_{14}, \mathrm{CO}_{2}, \mathrm{O}_{2}\right.$, $\mathrm{H}_{2}, \mathrm{~N}_{2}, \mathrm{He}, \mathrm{Ar}$ ) were analysed in a set of columns on two Agilent $7890 A$ gas chromatographs equipped with a gas sampling valve plumbed with a dual sample loop. The first sample loop is connected with flame ionization (FID) connected with a $50 \mathrm{~m} \times$ $0.53 \mathrm{~mm}$ i.d. alumina column and the second loop is connected with thermal conductivity (TCD) detectors connected with an 1/8" packed column with HayeSep Q 80/100 mesh and 1/8" packed column with molecular sieve $13 \mathrm{X}$ for the separation of $\mathrm{H}_{2}, \mathrm{CO}_{2}, \mathrm{O}_{2}, \mathrm{~N}_{2}, \mathrm{CH}_{4}$ and $\mathrm{CO}$. All compounds in the $\mathrm{C}_{1}-\mathrm{C}_{6}$ range are then separated by the alumina column. Argonium is used as a carrier gas. The GC oven is programmed: $60^{\circ} \mathrm{C}$ held for $1 \mathrm{~min}$, then increase to $90^{\circ} \mathrm{C}$ at the rate of $10^{\circ} \mathrm{C} / \mathrm{min}$, next increase to $190^{\circ} \mathrm{C}$ at a rate of $20^{\circ} \mathrm{C} / \mathrm{min}$ and finally held for $7 \mathrm{~min}$.

Stable isotope analyses were performed using the Finnigan Delta Plus mass spectrometer. The stable carbon isotope data are expressed in the $\delta$ notation $\left(\delta^{13} \mathrm{C}, \%\right.$ ) relative to VPDB on a scale such that NBS-22 (oil) is $-30.03 \%$. Analytical precision is estimated to be $\pm 0.2 \%$. The stable hydrogen isotope data are reported in the $\delta$ notation $\left(\delta^{2} \mathrm{H}, \%\right.$ o $)$ relative to the international standard, Vienna Standard Mean Ocean Water $(\mathrm{VSMOW}=0.0 \%$ ) and normalized to standard light arctic precipitation SLAP (2-point calibrations) as recommended by Coplen (2011). Analytical precision is estimated to be $\pm 3 \%$. The results of stable nitrogen isotope analyses are shown in the $\delta$-notation $\left(\delta^{15} \mathrm{~N}, \%\right)$ relative to the air nitrogen standard.
Analytical precision is estimated to be $\pm 0.4 \%$. Molecular nitrogen was separated chromatographically for stable nitrogen isotope analysis and then transmitted to the mass spectrometer via the on-line system.

\section{RESULTS}

\section{SOURCE ROCKS}

The Outer Carpathians - Dukla Unit. In the Dukla Unit, the Upper Cretaceous Inoceramian, Eocene Hieroglyphic sandstones and shales (Rdzawka beds), and Oligocene Menilite and Krosno beds were sampled and geochemically described. Rock-Eval results of currently analysed samples as well as those from archival investigations (Więcław, 2002; Kotarba and Koltun, 2006) are shown in Table 1. Only five and eight samples from the Leśniówka-2 borehole were collected from the first two lithostratigraphic units, respectively. These samples have total organic carbon (TOC) content and residual hydrocarbon potential $\left(S_{2}\right)$ usually $<1 \mathrm{wt} \% \%$ and $1 \mathrm{mg} \mathrm{HC} / \mathrm{g}$ rock, respectively (Table 1). Only in the Hieroglyphic shales (Rdzawka beds) the TOC values up to $1.73 \mathrm{wt} . \%$ and $\mathrm{S}_{2}$ up to $1.83 \mathrm{mg} \mathrm{HC} / \mathrm{g}$ rock were recorded in some layers (Table 1). The Menilite and Krosno beds are better sampled than are the units previously discussed. The Menilite beds have the highest organic carbon content in the Dukla Unit, up to 8.2 wt.\% (Table 1). Except for this sample, six samples have TOC content exceeding 5 wt.\% (Fig. 6). The residual hydrocarbon potential is generally $<5 \mathrm{mg} \mathrm{HC} / \mathrm{g}$ rock, exceeding this value only for eight samples (Fig. 6) collected from the 
Kobielnik exposure in the Skrzydlna tectonic window (Kb, Fig. 1). The highest organic carbon content and residual hydrocarbon potential (31 mg HC/g rock) were recorded for sample Kb/287. The TOC and $S_{2}$ content in the youngest lithostratigraphic unit, the Krosno beds, do not exceed $1.0 \mathrm{wt} . \%$ and $2.5 \mathrm{mg} \mathrm{HC} / \mathrm{g}$ rock, respectively (Table 1 and Fig. 6). The values of other Rock-Eval parameters and indices ( $T_{\max }$ temperature, production index, hydrogen index and oxygen index) are listed in Table 1; the distribution of $T_{\max }$ temperature and hydrogen index values are shown in Figure 6.

The Rock-Eval data, bitumen content and its fraction composition, stable carbon isotope composition of bitumen, its fractions and kerogen as well as values of indices calculated based on distributions of $n$-alkanes and isoprenoids of selected samples from the Menilite and Krosno beds are included in Appendix 2. The biomarker indices and elemental composition of kerogen and selected indices of phenanthrene and dibenzothiophene and their methyl derivatives and triaromatic steroids of 3 samples analysed from the Menilite beds are presented in Tables 4 and 5, respectively. The vitrinite reflectance values of 5 samples from the Inoceramian, Rdzawka and Menilite beds are listed in Table 6. Values of these parameters and indices indicate some differences between samples collected from the Skrzydlna tectonic window (the exposure in Kobielnik) and the remaining part of the Dukla unit (beneath the Magura unit overthrust).
The Outer Carpathians - Silesian Unit. The Lower Cretaceous Lgota, Upper Cretaceous Godula, Upper Cretaceous-Paleocene Istebna and Oligocene Menilite beds were characterized geochemically (Table 2). In the Lgota beds, sampled in the Muchówka-2 and Rajbrot-1 boreholes, the TOC and $\mathrm{S}_{2}$ contents are up to $1.22 \mathrm{wt} . \%$ and $1.04 \mathrm{mg} \mathrm{HC} / \mathrm{g}$ rock, respectively (Table 2). The TOC content in the Godula beds does not exceed $0.5 \mathrm{wt} . \%$ (Table 2). In the Istebna beds, sampled only in the Borzęta IG 1 borehole (Fig. 1) the TOC content usually ranges from 1 to 2 wt. \% (Table 2), however, the residual hydrocarbons content does not exceed $1 \mathrm{mg} \mathrm{HC} / \mathrm{g}$ rock (Table 2 and Fig. 6). Only two samples from the exposure at Lipnik (Fig. 1) were collected from the Menilite beds (Table 2). The highest organic carbon content (7.2 wt.\%) and residual hydrocarbon potential $(7.8 \mathrm{mg} \mathrm{HC} / \mathrm{g}$ rock) were recorded for sample $\mathrm{Ln} / 142$ (Appendix 2). Ranges and medians of the main Rock-Eval parameters and indices of all lithostratigraphic units investigated are shown in Table 2. Bitumen extracted from 3 samples (two from the Inoceramian and one from the Menilite beds) were analysed for $n$-alkane and isoprenoid distribution and for two of them (one from the Inoceramian and one from the Menilite beds) stable carbon isotope analysis of bitumen, their fractions and kerogen were conducted (Appendix 2). Biomarker and aromatic hydrocarbon analyses and elemental composition of kerogen were conducted for one sample from the Menilite beds (Ln/142, Tables 4 and 5).

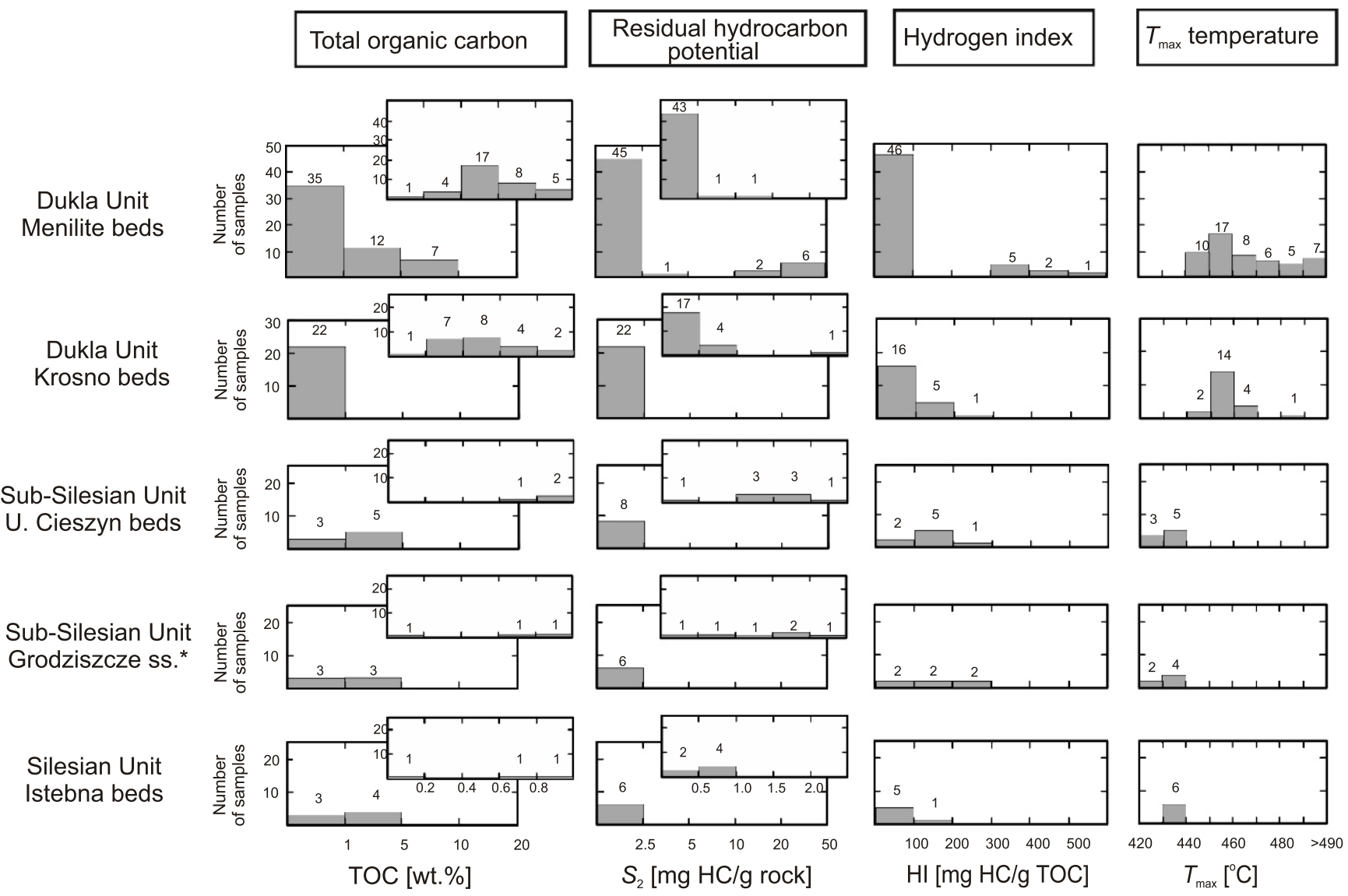

Fig. 6. Histograms of total organic carbon, residual petroleum potential, hydrogen index and $T_{\max }$ temperature for selected Outer Carpathian formations

* Grodziszcze sandstones 


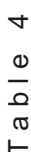

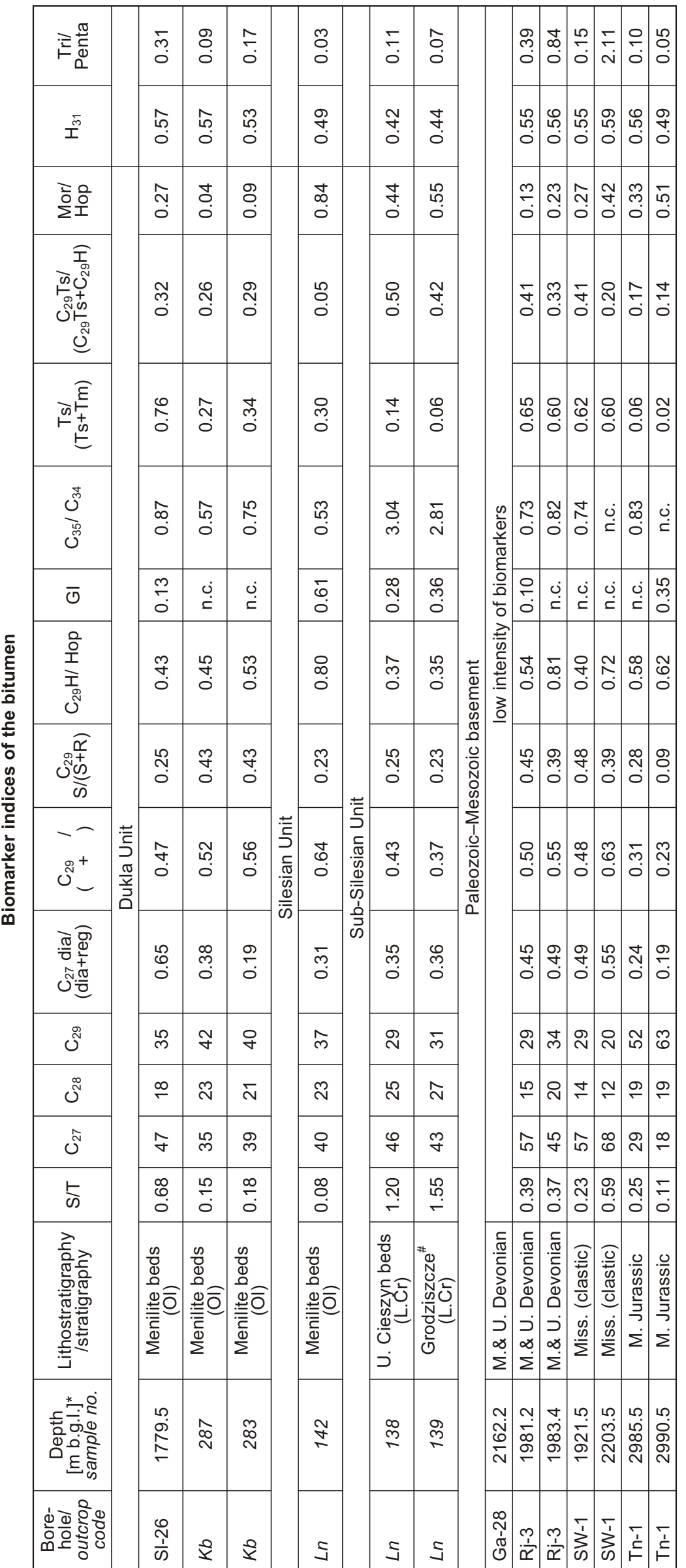

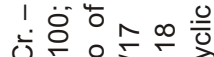

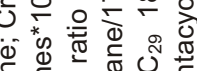

बid

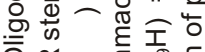

Ō

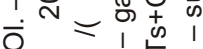
एँ

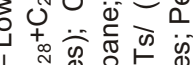

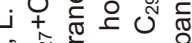

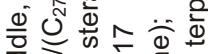

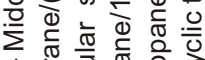

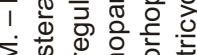

웅 和的

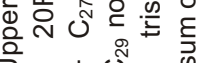

क्ष

ऽ نَّ

is "

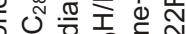

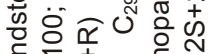

क

议

㐘

No

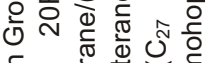

당

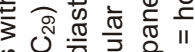

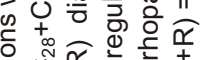

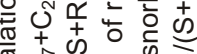

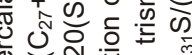

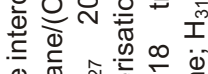

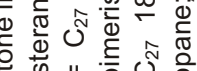

원

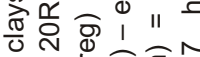

1 웡

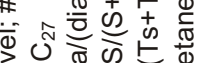

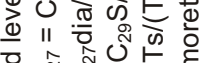

워ำ

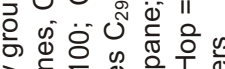

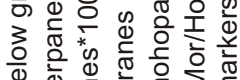

$1=$ \%

$\therefore \frac{\pi}{\omega} \frac{\bar{\omega}}{\omega}$

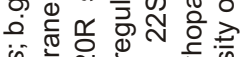

is 훙 त्र

पे $\bar{\sigma}$

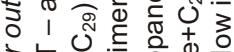

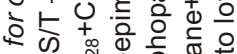

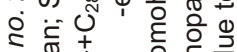

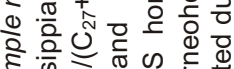

क्ष.

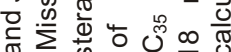

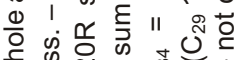

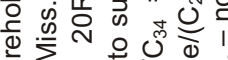

is 800 o w

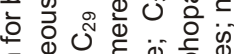

둴

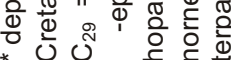




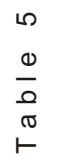

\begin{tabular}{|c|c|c|c|c|c|c|c|c|c|c|c|c|c|c|c|c|}
\hline 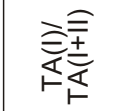 & $\mid \begin{array}{l}\bar{\infty} \\
0 \\
0\end{array}$ & is & $\mid \begin{array}{l}9 \\
m \\
0 \\
0\end{array}$ & {$\left[\begin{array}{c}\hat{1} \\
0 \\
0\end{array}\right]$} & $\stackrel{9}{\check{0}}$ & $\stackrel{N}{\check{O}}$ & $\begin{array}{l}\Gamma \\
\hat{0} \\
0\end{array}$ & : & 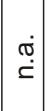 & 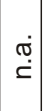 & $\begin{array}{c}9 \\
\stackrel{2}{*} \\
0\end{array}$ & $\hat{\imath}$ & & $\begin{array}{c}n \\
0 \\
0\end{array}$ & 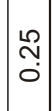 & \\
\hline 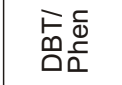 & $\mid \begin{array}{l}0 \\
0 \\
0\end{array}$ & $\mid$ & & $\mid \begin{array}{l}0 \\
0 \\
0\end{array}$ & $\begin{array}{l}\infty \\
\stackrel{0}{0} \\
0\end{array}$ & : & 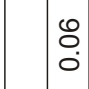 & $\frac{5}{0}$ & 㲾 & $\stackrel{\oplus}{\check{\check{c}}}$ & $\stackrel{+}{\leftarrow}$ & 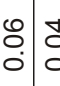 & 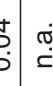 & $\begin{array}{l}0 \\
\vdots \\
0 \\
0\end{array}$ & 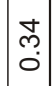 & \\
\hline 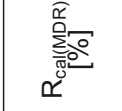 & $\begin{array}{l}\dot{ن} \\
\dot{E}\end{array}$ & $\left|\begin{array}{c}2 \\
0 \\
0\end{array}\right|$ & $\mid \begin{array}{c}\hat{N} \\
0 \\
0\end{array}$ & {$\left[\begin{array}{l}0 \\
0 \\
0\end{array}\right.$} & ֶֻ. & مُ & $\begin{array}{l}\hat{N} \\
0 \\
0\end{array}$ & $\mid \begin{array}{l}0 \\
0 \\
0 \\
0\end{array}$ & 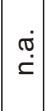 & 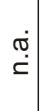 & 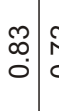 & \begin{tabular}{c|c}
$N$ & 0 \\
0 & 5
\end{tabular} & ن. & $\begin{array}{l}\hat{\sigma} \\
0 \\
0\end{array}$ & $\begin{array}{l}0 \\
\stackrel{0}{0} \\
0\end{array}$ & \\
\hline$\stackrel{\frac{\alpha}{Q}}{\Sigma}$ & $\mid \begin{array}{l}8 \\
0 \\
i \\
\wedge\end{array}$ & 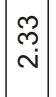 & 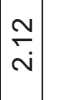 & $\begin{array}{l}\stackrel{8}{0} \\
- \\
r\end{array}$ & 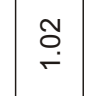 & $\begin{array}{l}\infty \\
\infty \\
0 \\
0\end{array}$ & م્ & 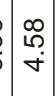 & 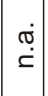 & $\stackrel{\oplus}{\dot{\Phi}}$ & \begin{tabular}{lll}
$\tilde{m}$ & \multirow{r}{*}{} & \multirow{r}{*}{}
\end{tabular} & 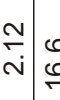 & 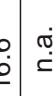 & : & N̦ & \\
\hline 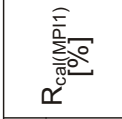 & $\mid \begin{array}{l}\vdots \\
\infty \\
0 \\
0\end{array}$ & $\mid \begin{array}{l}0 \\
0 \\
0\end{array}$ & $\mid \begin{array}{l}\mid \\
0 \\
0\end{array}$ & $\mid$ & $\stackrel{0}{0}$ & $\stackrel{0}{0}$ & 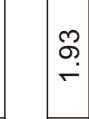 & $\mid \begin{array}{l}0 \\
0 \\
0 \\
0 \\
0\end{array}$ & 家 & 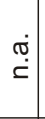 & 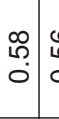 & \begin{tabular}{l|l}
0 & $\infty$ \\
$\substack{0 \\
0 \\
0}$ & $\infty$ \\
$c$
\end{tabular} & \begin{tabular}{l|l}
0 \\
$:$
\end{tabular} & : & : & \\
\hline$\frac{\bar{c}}{\frac{1}{2}}$ & $\mid \begin{array}{l}\infty \\
\\
0 \\
0\end{array}$ & 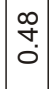 & 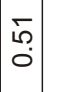 & $\begin{array}{c}\bar{m} \\
0 \\
0\end{array}$ & $\stackrel{m}{\stackrel{m}{0}}$ & 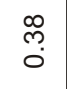 & & ma & 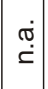 & 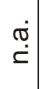 & \begin{tabular}{c}
\multirow{m}{*}{} \\
\hdashline \\
$o$
\end{tabular} & 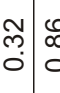 & & $\begin{array}{l}\text { Ș } \\
\vdots \\
0\end{array}$ & $\begin{array}{c}\hat{N} \\
0 \\
0\end{array}$ & \\
\hline$\frac{0}{m}$ & $\left|\begin{array}{l}\infty \\
0 \\
0 \\
0\end{array}\right|$ & $\left|\begin{array}{l}m \\
\tilde{O} \\
0 \\
0\end{array}\right|$ & 号 & 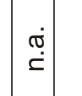 & 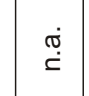 & 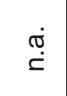 & $\mid$ & 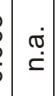 & $\begin{array}{l}m \\
0 \\
0 \\
0\end{array}$ & 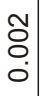 & 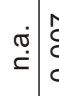 & $\hat{o}$ & 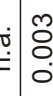 & $\begin{array}{l}0 \\
0 \\
0 \\
0 \\
0\end{array}$ & 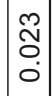 & \\
\hline $\begin{array}{l}0.0 \\
\frac{0}{0} \\
\frac{\pi}{0} \\
0 .\end{array}$ & 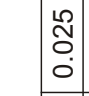 & \begin{tabular}{|l|} 
\\
\\
0 \\
0
\end{tabular} & $\mid \begin{array}{l}0 \\
0 \\
0 \\
0 \\
\end{array}$ & $\stackrel{\oplus}{\dot{\oplus}}$ & 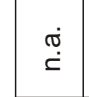 & 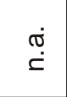 & $\begin{array}{ll}m \\
\\
0 \\
0\end{array}$ & 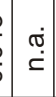 & $\begin{array}{l}\hat{N} \\
\bar{o} \\
0\end{array}$ & $\begin{array}{l}\tilde{N} \\
0 \\
0\end{array}$ & 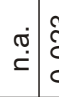 & 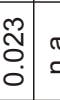 & 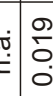 & \begin{tabular}{|l|}
0 \\
$\vdots$ \\
$\vdots$ \\
0
\end{tabular} & $\begin{array}{l}N \\
\stackrel{2}{0} \\
0\end{array}$ & \\
\hline O & $\mid \begin{array}{l}0 \\
0 \\
0\end{array}$ & $\mid \begin{array}{l}\tilde{O} \\
0 \\
0\end{array}$ & $\mid \begin{array}{l}0 \\
0 \\
0 \\
0\end{array}$ & 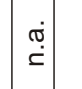 & 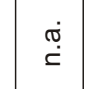 & 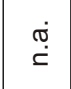 & 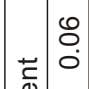 & 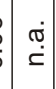 & o & $\begin{array}{l}\infty \\
0 \\
0 \\
0\end{array}$ & $\stackrel{\oplus}{\dot{\Phi}} \stackrel{\hat{c}}{\mathrm{c}}$ & $\begin{array}{l}\hat{0} \\
0 \\
0\end{array}$ & 萬 & $\begin{array}{l}5 \\
\vdots \\
0 \\
0\end{array}$ & $\stackrel{9}{\circ}$ & \\
\hline$\frac{O}{1}$ & 童 & $\mid \begin{array}{l}0 \\
\stackrel{-}{\prime}\end{array}$ & {$\left[\begin{array}{l}8 \\
0 \\
0\end{array}\right]$.} & 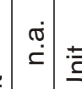 & 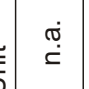 & 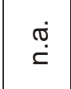 & 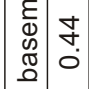 & $\mid \begin{array}{l}\dot{\oplus} \\
\dot{x}\end{array}$ & $\stackrel{g}{\circ}$ & $\begin{array}{c}\hat{N} \\
0\end{array}$ & $\stackrel{\dot{\Phi}}{\dot{\varepsilon}} \dot{\Sigma}$ & 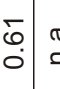 & 范 & $\begin{array}{l}0 \\
0 \\
0\end{array}$ & $\begin{array}{c}\hat{N} \\
0 \\
0\end{array}$ & \\
\hline 䓻 & & & 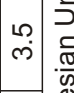 & 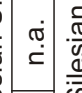 & $\stackrel{\text { Ф் }}{\check{c}}$ & 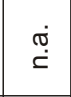 & \begin{tabular}{|c|c} 
& 0 \\
0 & - \\
0 \\
0 \\
0 \\
0
\end{tabular} & : & : & :े. & $\stackrel{\oplus}{\dot{\Phi}} \stackrel{4}{=}$ & $\stackrel{n}{\sim} \stackrel{\pi}{5}$ & ثٌ & $\dot{p} \mid \hat{\dot{\theta}}$ & 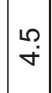 & \\
\hline 莣 & 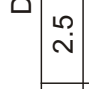 & $\stackrel{\leftrightarrow}{-}$ & $\stackrel{\leftrightarrow}{-}$ & 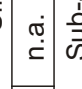 & 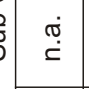 & $\stackrel{\text { ஸ் }}{\check{\check{d}}}$ & 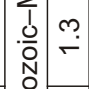 & \begin{tabular}{|l|l|}
$\dot{\oplus}$ \\
$\dot{\Sigma}$ \\
$\dot{x}$
\end{tabular} & $\stackrel{f}{-}$ & $\overline{\mathrm{N}}$ & 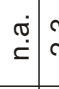 & $\stackrel{m}{\mathrm{~N}})$ & : & $\hat{0}$ & $\stackrel{\circ}{\stackrel{2}{ }}$ & \\
\hline है & is & 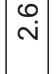 & {$\left[\begin{array}{l}\infty \\
\infty \\
\omega\end{array}\right]$} & $\stackrel{\oplus}{\check{\infty}}$ & $\stackrel{\text { }}{\check{\Sigma}}$ & 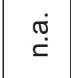 & 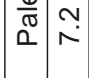 & 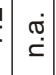 & $\stackrel{\stackrel{P}{+}}{\dot{f}}$ & $\stackrel{m}{\sigma}$ & 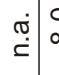 & 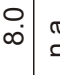 & مُ & 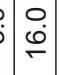 & ? & \\
\hline$\frac{\bar{c}}{\frac{\pi}{5}}$ & 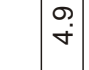 & $\stackrel{m}{\sim}$ & 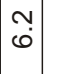 & 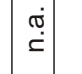 & 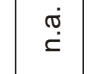 & $\stackrel{\text { }}{\stackrel{\Phi}{\complement}}$ & N) & 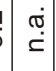 & $\stackrel{\infty}{\sim}$ & $\stackrel{m}{\omega}$ & $\stackrel{\oplus}{\dot{\Xi}} \stackrel{9}{ }$ & \begin{tabular}{l|l}
$\stackrel{N}{r}$ & $\pi$ \\
$\check{\sigma}$
\end{tabular} & 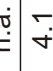 & $\stackrel{\sim}{\sim}$ & $\stackrel{\leftrightarrow}{\dot{r}}$ & \\
\hline$\frac{\bar{\omega}}{\bar{w}}$ & $\left|\begin{array}{c}0 \\
\dot{\infty} \\
\infty\end{array}\right|$ & $\bar{\infty}$ & $\mid \begin{array}{c}\hat{N} \\
\infty\end{array}$ & 官 & 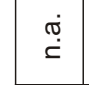 & $\stackrel{\text { }}{\check{C}}$ & $\begin{array}{l}\overline{\mathbf{x}} \\
\infty\end{array}$ & 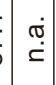 & $\mid \begin{array}{c}0 \\
i \\
\infty \\
\infty\end{array}$ & $\begin{array}{c}\infty \\
i \\
\infty \\
\infty\end{array}$ & 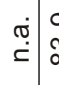 & 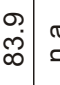 & |: & $\frac{n}{\mathrm{~N}}$ & $\frac{9}{\bar{K}}$ & \\
\hline 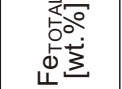 & $\begin{array}{l}0 \\
\dot{m}\end{array}$ & $\begin{array}{l}m \\
\dot{m} \\
\dot{p}\end{array}$ & $\begin{array}{c}m \\
\sigma\end{array}$ & $\begin{array}{c}\stackrel{\oplus}{\oplus} \\
\dot{\Sigma}\end{array}$ & 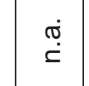 & $\stackrel{\text { }}{\check{\Sigma}}$ & 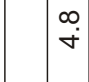 & : & ஸֶ. & $\stackrel{N}{N}$ & 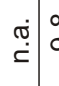 & \begin{tabular}{c|c}
$\infty$ \\
$\infty$ \\
$\infty$ & $\pi$ \\
$c$
\end{tabular} & 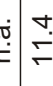 & $\bar{i}$ & @) & \\
\hline 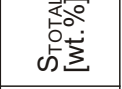 & $\hat{\dot{\sigma}}$ & & $\mid \begin{array}{c}\vec{p} \\
\stackrel{p}{r}\end{array}$ & 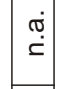 & $\stackrel{\text { }}{\check{\Sigma}}$ & 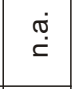 & $\begin{array}{l}+ \\
\bullet\end{array}$ & 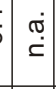 & 占 & $\stackrel{a}{i}$ & 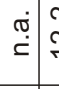 & 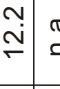 & : & $\infty$ & $\begin{array}{l}0 \\
\dot{\sim}\end{array}$ & \\
\hline 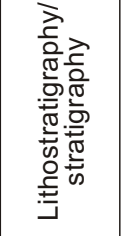 & 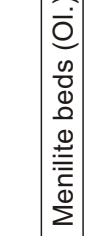 & 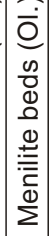 & 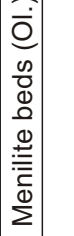 & 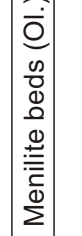 & 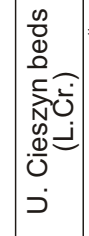 & 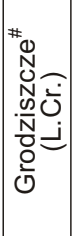 & 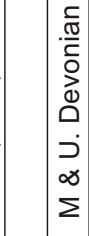 & 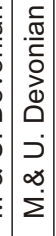 & 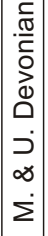 & 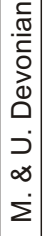 & 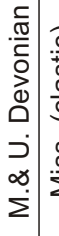 & 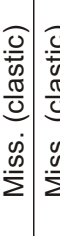 & 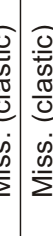 & 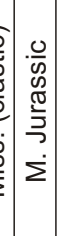 & 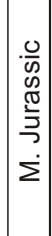 & \\
\hline 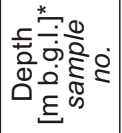 & 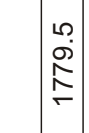 & $\stackrel{\infty}{\sim}$ & $\stackrel{\hat{\infty}}{N}$ & $\underset{y}{\mathfrak{Z}}$ & $\stackrel{\infty}{?}$ & ભి & 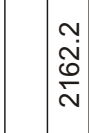 & 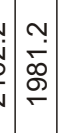 & 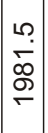 & $\mid \begin{array}{c}0 \\
0 \\
0 \\
0 \\
0 \\
\\
\end{array}$ & 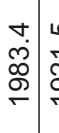 & 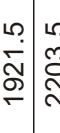 & & 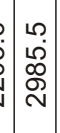 & 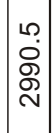 & \\
\hline $\begin{array}{lll}0 & 0 \\
0 & 0 & 0 \\
0 & 0 \\
0 & 0 & 0 \\
0\end{array}$ & $\left|\begin{array}{c}0 \\
\frac{1}{\omega} \\
\omega\end{array}\right|$ & 8 & 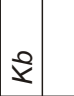 & $\Xi$ & ऽ & ऽ & & & & & $\frac{m}{\alpha} \frac{i}{d}$ & $\sum_{\omega}^{1} \sum_{0}^{T}$ & & $\mid \begin{array}{c}\bar{s} \\
\dot{s}\end{array}$ & 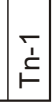 & \\
\hline
\end{tabular}


Vitrinite reflectance of organic matter

\begin{tabular}{|c|c|c|c|c|c|c|}
\hline $\begin{array}{l}\text { Borehole/ } \\
\text { outcrop }\end{array}$ & Code & $\begin{array}{l}\text { Depth [m b.g.I.] } \\
\text { sample no. }\end{array}$ & Stratigraphy/lithostratigraphy & $\begin{array}{c}R_{r} \\
{[\%]}\end{array}$ & $\begin{array}{l}\text { Stdv } \\
{[\%]}\end{array}$ & $n$ \\
\hline \multicolumn{7}{|c|}{ Dukla Unit } \\
\hline Leśniówka-2 & Le-2 & 5004.0 & Inoceramian beds (U. Cr.) & 1.00 & 0.076 & 72 \\
\hline Leśniówka-2 & Le-2 & 3792.0 & Hieroglyphic ss. \& sh. (E.) (Rdzawka beds) & 0.74 & 0.057 & 118 \\
\hline Leśniówka-2 & Le-2 & 2445.0 & Menilite beds (OI.) & 0.75 & 0.076 & 104 \\
\hline Szczawa & Sz & 152 & Menilite beds (OI.) & 1.29 & 0.270 & 4 \\
\hline Szczawa & Sz & 153 & Menilite beds (OI.) & 1.55 & 0.143 & 6 \\
\hline \multicolumn{7}{|c|}{ Paleozoic-Mesozoic basement } \\
\hline Rajsko-3 & Rj-3 & 1983.4 & M. \& U. Devonian & $0.92 \$$ & 0.116 & 55 \\
\hline Rajsko-3 & Rj-3 & 2453.5 & M. \& U. Devonian & 1.00 & 0.136 & 65 \\
\hline
\end{tabular}

$R_{r}$ - mean random vitrinite reflectance; Stdv - standard deviation; $n$ - number of measurements; $\$$ - vitrinite-like alginite; ss. - sandstones; sh. - shales; E - Eocene; other explanations as in Table 4

The Outer Carpathians - Sub-Silesian Unit. The Lower Cretaceous Upper Cieszyn and Grodziszcze beds were geochemically characterized. The TOC content in both lithological units changes from 0.79 to 1.63 and from 0.19 to $1.38 \mathrm{wt} \%$, respectively (Table 2). The TOC content in the Upper Cieszyn beds usually exceeds $1 \mathrm{wt} . \%$ (Fig. 6). The residual hydrocarbon potential of both units does not exceed $2.5 \mathrm{mg} \mathrm{HC} / \mathrm{g}$ rock (Table 2 and Fig. 6). The ranges, medians of the remaining Rock-Eval parameters and indices are listed in Table 2. $n$-alkane and isoprenoid distribution was analysed for 5 samples ( 3 from the Upper Cieszyn and 2 from claystone intercalations within the Grodziszcze sandstones) and for 4 of them (2 from the Upper Cieszyn and 2 from the Grodziszcze beds) stable carbon isotope analysis of bitumen, their fractions and kerogen were conducted (Appendix 2). Biomarker and aromatic hydrocarbon analyses were conducted for 2 samples (one sample from each unit; Tables 4 and 5).

The Paleozoic-Mesozoic basement. The Devonian and Mississippian strata from the Paleozoic basement were geochemically characterized (Table 3). The TOC content in the Lower Devonian strata in the study area does not exceed 0.5 wt. \% (Table 3). The organic carbon content in the Middle and Upper Devonian strata usually is $<0.5 \mathrm{wt} . \%$, but in some places it may reach even 2.6 wt.\% (Table 3 and Appendix 2). In seven samples the TOC content was recorded $>1 \mathrm{wt}$ \% (Fig. 7 ). The residual hydrocarbon potential ranges from 0.00 to $7.4 \mathrm{mg} \mathrm{HC} / \mathrm{g}$ rock (Table 3, Appendix 2 and Fig. 7). The ranges of other Rock-Eval parameters and indices are shown in Table 3 and Figure 7 . The results of $n$-alkane and isoprenoid distribution analyses (4 samples) as well as stable carbon isotope composition (5 samples) are shown in Appendix 2. Table 4 includes the biomarker indices of 3 analysed samples. In one of these (Ga-28/2162.2) a low content of hydrocarbons was recorded, therefore the ratios were not calculated. The elemental composition of kerogen as well as selected indices of phenanthrene and dibenzothiophene, their methyl derivatives and triaromatic steroids were determined for 3 samples (Tables 4 and 5). The vitrinite (or vitrinite-like alginite) reflectance was determined for 2 samples (Table 6).

The Mississippian carbonates were described based on the results of geochemical analyses of 51 core samples from the Łąkta-2, Strzelce Wielkie-1, Rajbrot-1 and Rajbrot-2 boreholes (Fig. 1). The TOC content was variable and ranged from 0.01 to 5 wt.\% (Table 3), but low values ( $<1$ wt.\%) dominated (Fig. 7 ). The residual hydrocarbon potential was comparable to the TOC - scatter, ranging from 0.13 to $13.7 \mathrm{mg} \mathrm{HC} / \mathrm{g}$ rock with most val- ues below $2.5 \mathrm{mg} \mathrm{HC} / \mathrm{g}$ rock (Table 3 and Fig. 7). Results of the additional analyses of these samples were published earlier by Kotarba et al. (2004a) and Wróbel et al. (2016).

The Mississippian clastic rocks were characterized based on 19 samples collected from the Strzelce Wielkie-1 borehole (Fig. 1); 11 of these had been evaluated earlier by Kotarba et al. (2004b) and 2 samples came from Matyasik et al. (2001). These samples show that the av. TOC was $\sim 1.05$ wt.\% (Table 3 ), and the residual hydrocarbon potential only once exceeded $2.5 \mathrm{mg} \mathrm{HC} / \mathrm{g}$ rock (Table 3 and Fig. 7). The $n$-alkane and isoprenoid distribution was determined for 3 samples and stable carbon isotope composition for 2 samples (Appendix 2). The biomarker, aromatic hydrocarbons and kerogen elemental analyses were conducted for 2 samples each (Tables 4 and 5).

From the Mesozoic basement, only the Middle and Upper Jurassic strata were characterized. In the Middle Jurassic strata the TOC values varied from 0 to $15.7 \mathrm{wt}$ \% (Table 3). In 8 samples the TOC value exceeded $10 \mathrm{wt} \%$ (Fig. 7). All the organic-rich samples were collected from the Tarnawa-1 borehole (Fig. 1), mainly from lenses of lignite. These samples also had residual hydrocarbon potential of up to $43.1 \mathrm{mg} \mathrm{HC} / \mathrm{g}$ rock (Table 3). In the other boreholes sampled (Borzęta IG 1, Rajbrot-1 and Strzelce Wielkie-1), the TOC values in the strata investigated were $<0.5$ wt. $\%$. The Rock-Eval pyrolysis data, $n$-alkane and isoprenoid distribution and stable carbon isotope composition of 2 samples selected from the Tarnawa-1 borehole are given in Appendix 2. For the same 2 samples kerogen elemental composition, biomarker and aromatic hydrocarbon distribution were conducted (Tables 4 and 5). No additional analyses were conducted on the Upper Jurassic rocks in the present study.

\section{NATURAL GAS}

Natural gas accumulated in the Upper Cretaceous to Lower Miocene sandstone reservoirs of the Dukla and Silesian units of the Outer Carpathians in the study area varies in molecular and isotopic compositions. Molecular composition, gas indices and stable isotope ratios vary within the following ranges (Tables 7 and 8; Kotarba, 1987, 1992; Kotarba et al., 2009): $\mathrm{CH}_{4}$ from 86.3 to 98.9 vol\%, $\mathrm{C}_{2} \mathrm{H}_{6}$ from 0.19 to $7.34 \mathrm{vol} \%, \mathrm{C}_{3} \mathrm{H}_{8}$ from 0.05 to $3.35 \mathrm{vol} \%, i \mathrm{C}_{4} \mathrm{H}_{10}$ from 0.004 to $0.69 \mathrm{vol} \%, n \mathrm{C}_{4} \mathrm{H}_{10}$ from 0.007 to $0.91 \mathrm{vol} \%, \mathrm{CO}_{2}$ from 0.09 to $0.24 \mathrm{vol} \%, \mathrm{~N}_{2}$ from 0.54 to $4.50 \mathrm{vol} \%$, He from 0.003 to 0.014 vol\%, $\mathrm{H}_{2}$ from 0.007 to 0.02 , 


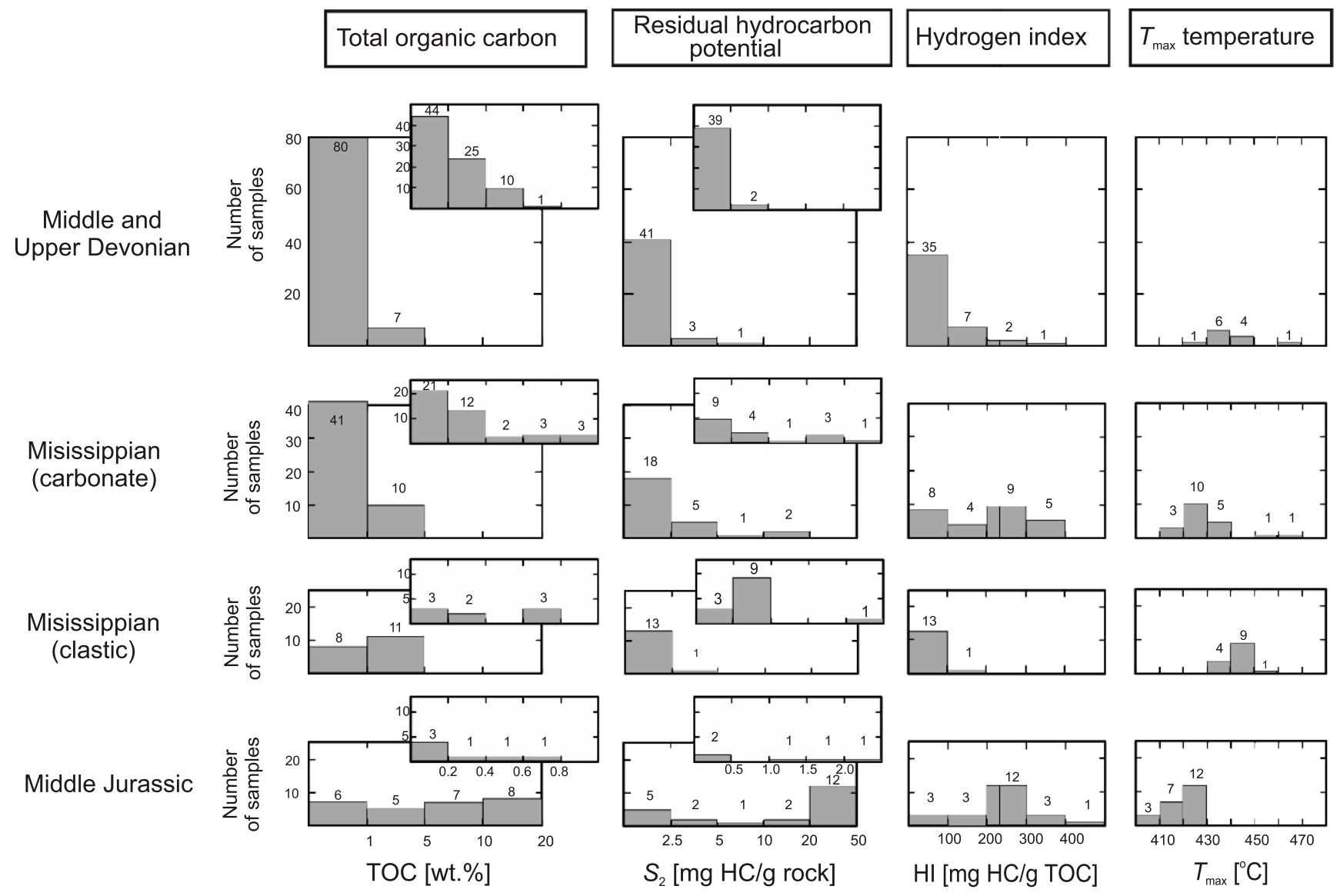

Fig. 7. Histograms of total organic carbon, residual petroleum potential, hydrogen index and $T_{\max }$ temperature for selected strata of Paleozoic-Mesozoic basement

Table 7

Molecular composition of natural gas

\begin{tabular}{|c|c|c|c|c|c|c|c|c|c|c|c|c|c|c|c|}
\hline \multirow{2}{*}{ Borehole } & \multirow{2}{*}{$\begin{array}{c}\text { Sample } \\
\text { code }\end{array}$} & \multicolumn{14}{|c|}{ Component (vol\%) } \\
\hline & & $\mathrm{CH}_{4}$ & $\mathrm{C}_{2} \mathrm{H}_{6}$ & $\mathrm{C}_{3} \mathrm{H}_{8}$ & $i \mathrm{C}_{4} \mathrm{H}_{10}$ & $n \mathrm{C}_{4} \mathrm{H}_{10}$ & $i \mathrm{C}_{5} \mathrm{H}_{12}$ & $n \mathrm{C}_{5} \mathrm{H}_{12}$ & $\mathrm{C}_{6} \mathrm{H}_{14}$ & $\mathrm{~N}_{2}$ & $\mathrm{CO}_{2}$ & $\mathrm{Ar}$ & $\mathrm{He}$ & $\mathrm{H}_{2}$ & $\mathrm{H}_{2} \mathrm{~S}$ \\
\hline \multicolumn{16}{|c|}{ Outer Carpathians - Dukla Unit } \\
\hline Leśniówka-2 & Lk-2 & 86.3 & 7.34 & 3.35 & 0.41 & 0.73 & & & 0.07 & 1.40 & 0.09 & 0.01 & 0.01 & 0.02 & 0.00 \\
\hline \multicolumn{16}{|c|}{ Mesozoic basement } \\
\hline Grobla-50 & Ga-50 & 79.3 & 1.31 & 0.58 & 0.28 & 0.39 & 0.11 & 0.11 & 0.07 & 17.6 & 0.17 & n.a. & 0.03 & 0.04 & 0.04 \\
\hline Rajsko-2 & $\mathrm{Rj}-2$ & 74.9 & 0.68 & 0.27 & 0.12 & 0.20 & 0.08 & 0.10 & 0.17 & 22.6 & 0.39 & n.a. & 0.10 & 0.16 & 0.28 \\
\hline Rylowa-5 & Ry-5 & 76.9 & 0.63 & 0.23 & 0.10 & 0.16 & 0.06 & 0.07 & 0.11 & 20.6 & 0.51 & n.a. & 0.10 & 0.00 & 0.59 \\
\hline
\end{tabular}

${ }^{*} i \mathrm{C}_{5} \mathrm{H}_{10}+n \mathrm{C}_{5} \mathrm{H}_{10} ;$ n.a. - not analysed

Table 8

Molecular indices and isotopic composition of natural gas

\begin{tabular}{|c|c|c|c|c|c|c|c|c|c|c|c|c|c|c|}
\hline \multirow[b]{2}{*}{ Borehole } & \multirow[b]{2}{*}{$\begin{array}{c}\text { Sample } \\
\text { code }\end{array}$} & \multicolumn{3}{|c|}{ Molecular indices } & \multicolumn{10}{|c|}{ Stable isotopes [\%o] } \\
\hline & & $\mathrm{C}_{\mathrm{HC}}$ & CDMI & $i \mathrm{C}_{4} / n \mathrm{C}_{4}$ & $\begin{array}{l}\delta^{13} \mathrm{C} \\
\left(\mathrm{CH}_{4}\right)\end{array}$ & $\begin{array}{l}\delta^{2} \mathrm{H} \\
\left(\mathrm{CH}_{4}\right)\end{array}$ & $\begin{array}{l}\delta^{13} \mathrm{C} \\
\left(\mathrm{C}_{2} \mathrm{H}_{6}\right)\end{array}$ & $\begin{array}{l}\delta^{13} \mathrm{C} \\
\left(\mathrm{C}_{3} \mathrm{H}_{8}\right)\end{array}$ & $\begin{array}{l}\delta^{13} \mathrm{C} \\
\left(i \mathrm{C}_{4} \mathrm{H}_{10}\right)\end{array}$ & $\begin{array}{c}\delta^{13} \mathrm{C} \\
\left(n \mathrm{C}_{4} \mathrm{H}_{10}\right)\end{array}$ & $\begin{array}{c}\delta^{13} \mathrm{C} \\
\left(i \mathrm{C}_{5} \mathrm{H}_{12}\right)\end{array}$ & $\begin{array}{c}\delta^{13} \mathrm{C} \\
\left(n \mathrm{C}_{5} \mathrm{H}_{12}\right)\end{array}$ & $\begin{array}{l}\delta^{13} \mathrm{C} \\
\left(\mathrm{CO}_{2}\right)\end{array}$ & $\begin{array}{l}\delta^{15} \mathrm{~N} \\
\left(\mathrm{~N}_{2}\right)\end{array}$ \\
\hline \multicolumn{15}{|c|}{ Outer Carpathians - Dukla Unit } \\
\hline Leśniówka-2 & Lk-2 & 8.1 & 0.10 & 0.56 & -37.5 & -156 & -26.8 & -25.2 & n.a. & n.a. & n.a. & n.a. & n.a. & n.a. \\
\hline \multicolumn{15}{|c|}{ Mesozoic basement } \\
\hline Grobla-50 & Ga-50 & 42.0 & 0.21 & 0.72 & -42.9 & -153 & -27.8 & -28.0 & -27.4 & -26.8 & -26.8 & -27.4 & -19.3 & 0.8 \\
\hline Rajsko-2 & $\mathrm{Rj}-2$ & 78.8 & 0.52 & 0.60 & -37.4 & -148 & -28.4 & -27.2 & -26.9 & -26.6 & -26.4 & -27.1 & -27.9 & 1.8 \\
\hline Rylowa-5 & Ry-5 & 89.4 & 0.66 & 0.63 & -37.4 & -151 & -28.5 & -27.4 & -27.8 & -27.3 & -27.0 & -26.9 & -25.0 & 1.3 \\
\hline
\end{tabular}


hydrocarbon index $\left[\mathrm{C}_{\mathrm{HC}}=\mathrm{CH}_{4} /\left(\mathrm{C}_{2} \mathrm{H}_{6}+\mathrm{C}_{3} \mathrm{H}_{8}\right)\right]$ from 8.1 to 410 carbon dioxide/methane index $\left\{\mathrm{CDMl}=\left(\mathrm{CO}_{2} /\left[\mathrm{CO}_{2}+\mathrm{CH}_{4}\right]\right)\right.$ 100 (\%)\} from 0.10 to $0.27 \%, i \mathrm{C}_{4} \mathrm{H}_{10} / n \mathrm{C}_{4} \mathrm{H}_{10}$ from 0.17 to 0.91 , $\delta^{13} \mathrm{C}\left(\mathrm{CH}_{4}\right)$ from -64.6 to $-34.2 \%$, $\delta^{2} \mathrm{H}\left(\mathrm{CH}_{4}\right)$ from -183 to $-151 \%$, $\delta^{13} \mathrm{C}\left(\mathrm{C}_{2} \mathrm{H}_{6}\right)$ from -31.4 to $-26.8 \%$, $\delta^{13} \mathrm{C}\left(\mathrm{C}_{3} \mathrm{H}_{8}\right)$ from -25.6 to $-24.9 \%$. The gas is wet and contains pentanes $\left(\mathrm{C}_{5}\right)$ from 0.004 to $0.73 \mathrm{vol} \%$ and hexanes $\left(C_{6}\right)$ from 0.002 to $0.76 \mathrm{vol} \%$.

Natural gas accumulated in the Mesozoic basement both in the Upper Jurassic carbonate and Upper Cretaceous sandstone reservoirs of the Mesozoic basement in the study area also varies in molecular and isotopic compositions. Natural gas is wet and contains hexanes $\left(C_{6}\right)$ from 0 to $0.49 \mathrm{vol} \%$. Molecular composition, gas indices and stable isotope ratios vary within the following ranges (Tables 7 and 8; Kotarba, 2012; Kotarba and Jawor, 1993; Kotarba and Nagao, 2008): $\mathrm{CH}_{4}$ from 68.7 to 98.6 vol\%, $\mathrm{C}_{2} \mathrm{H}_{6}$ from 0.16 to 9.32 vol\%, $\mathrm{C}_{3} \mathrm{H}_{8}$ from 0.06 to 9.09 vol\%, $i \mathrm{C}_{4} \mathrm{H}_{10}$ from 0.05 to $2.64 \mathrm{vol} \%, n \mathrm{C}_{4} \mathrm{H}_{10}$ from 0.02 to $3.62 \mathrm{vol} \%, i \mathrm{C}_{5} \mathrm{H}_{12}$ from 0.01 to $0.88 \mathrm{vol} \%, n \mathrm{C}_{5} \mathrm{H}_{12}$ from 0.00 to $0.93 \mathrm{vol} \%, \mathrm{CO}_{2}$ from 0.00 to $4.29 \mathrm{vol} \%, \mathrm{~N}_{2}$ from 1.10 to $22.6 \mathrm{vol} \%$, He from 0.00 to $0.12 \mathrm{vol} \%, \mathrm{H}_{2}$ from 0.00 to $0.81 \mathrm{vol} \%, \mathrm{H}_{2} \mathrm{~S}$ from 0.00 to $0.59 \mathrm{vol} \%$, hydrocarbon index $\left(\mathrm{C}_{\mathrm{HC}}\right)$ from 3.7 to 448 , carbon dioxide/methane index (CDMI) from 0.00 to $5.85 \%, i \mathrm{C}_{4} \mathrm{H}_{10} / n \mathrm{C}_{4} \mathrm{H}_{10}$ from 0.60 to $2.5, \delta^{13} \mathrm{C}\left(\mathrm{CH}_{4}\right)$ from -67.3 to $-36.4 \%, \delta^{2} \mathrm{H}\left(\mathrm{CH}_{4}\right)$ from -191 to $-142 \%$, $\delta^{13} \mathrm{C}\left(\mathrm{C}_{2} \mathrm{H}_{6}\right)$ from -53.0 to $-26.6 \%$, $\delta^{13} \mathrm{C}\left(\mathrm{C}_{3} \mathrm{H}_{8}\right)$ from -29.8 to $-24.5 \%$, $\delta^{13} \mathrm{C}\left(\mathrm{iC}_{4} \mathrm{H}_{10}\right)$ from -27.8 to $-26.9 \%$, $\delta^{13} \mathrm{C}\left(n \mathrm{C}_{4} \mathrm{H}_{10}\right)$ from -27.3 to $-25.3 \%$ o, $\delta^{13} \mathrm{C}\left(\mathrm{CO}_{2}\right)$ from -27.9 to $-10.4 \%$ and $\delta^{15} \mathrm{~N}\left(\mathrm{~N}_{2}\right) 0.8$ and $1.8 \%$ o. 00 to $0.47 \mathrm{vol} \%$.

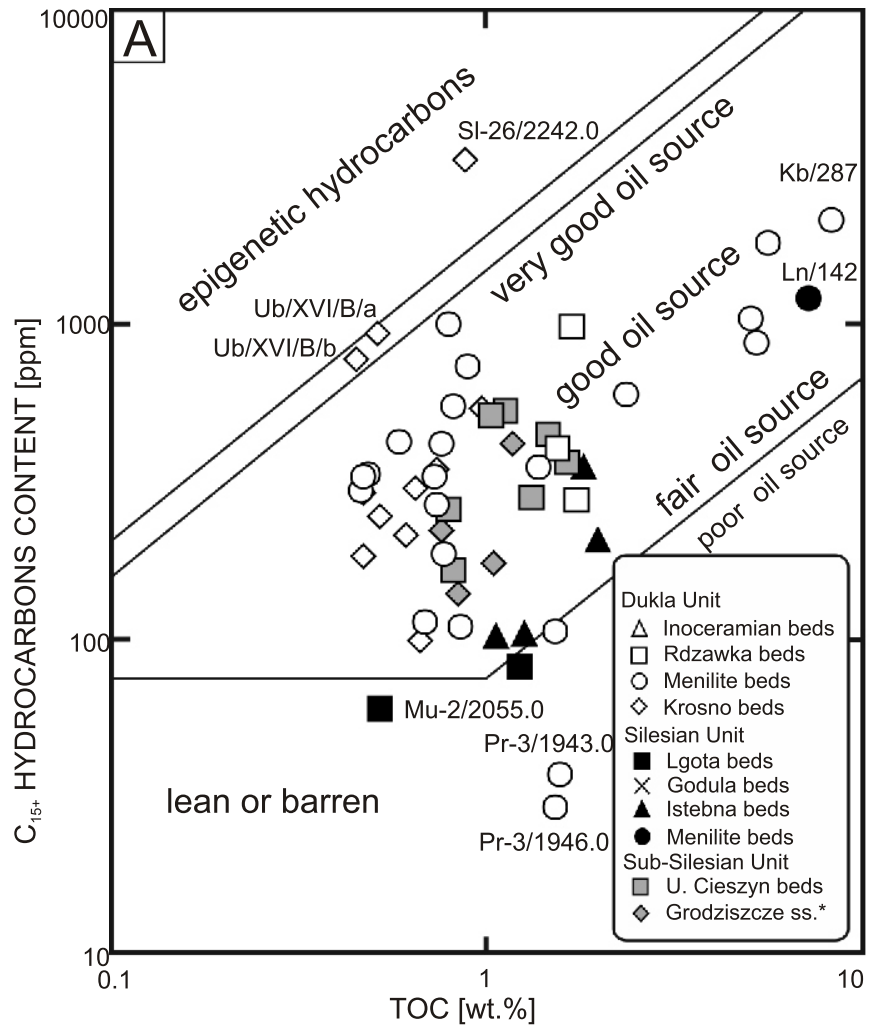

\section{INTERPRETATION AND DISCUSSION}

\section{SOURCE ROCKS}

The Outer Carpathians - Dukla Unit. The detailed hydrocarbon potential of the Upper Cretaceous Inoceramian and Eocene Hieroglyphic shales (Rdzawka beds), is difficult to establish due to the unrepresentative population of samples. However, judging from this small population, these samples presumably have poor hydrocarbon potential (Table 1). Only in the Hieroglyphic shales, source rocks of moderate potential for hydrocarbon generation occur in some layers (Table 1). The Menilite beds have the highest organic carbon content in the Dukla Unit (Table 1; Figs. 6 and 8A). However, although high TOC content was measured in these beds, the residual hydrocarbon potential was generally low. Only in the Skrzydlna tectonic window (Kobielnik exposure, Kb; Fig. 1) was a very good level of hydrocarbon potential recorded. These data indicate variable hydrocarbon potential of the Menilite beds, usually poor and locally moderate or good. Due to their low TOC and $S_{2}$ contents, the youngest lithostratigraphic unit, the Krosno beds, have poor hydrocarbon potential (Table 1 and Fig. 6).

Based on the extractable hydrocarbon content (Fig. 8A) it can be concluded that good oil source rock levels occur within the Menilite beds and Hieroglyphic shales (Rdzawka beds). However, a very high content of saturated hydrocarbons in bitumen extracted from some samples of the Menilite beds (up to 79 wt.\%; Fig. 9A) suggests the presence of epigenetic hydrocar-

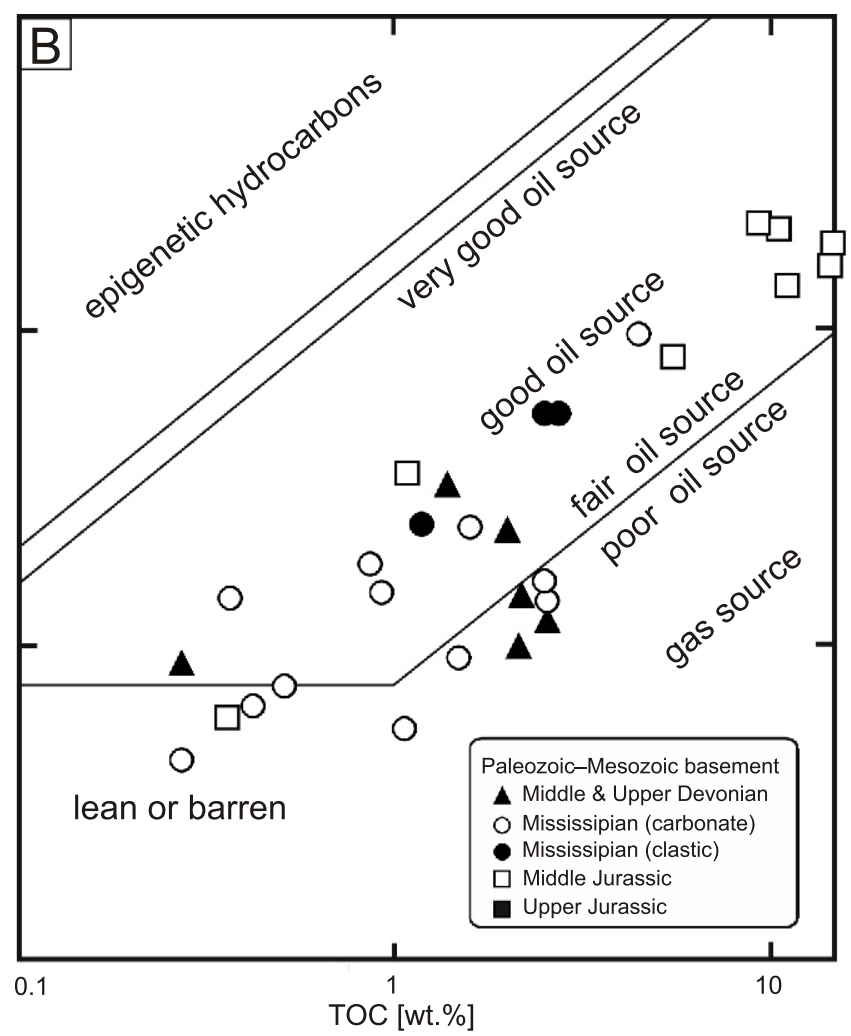

Fig. 8. Source possibility of the Outer Carpathian lithostratigraphic units (A) and Paleozoic-Mesozoic basement (B) in terms of extractable hydrocarbons and TOC content 


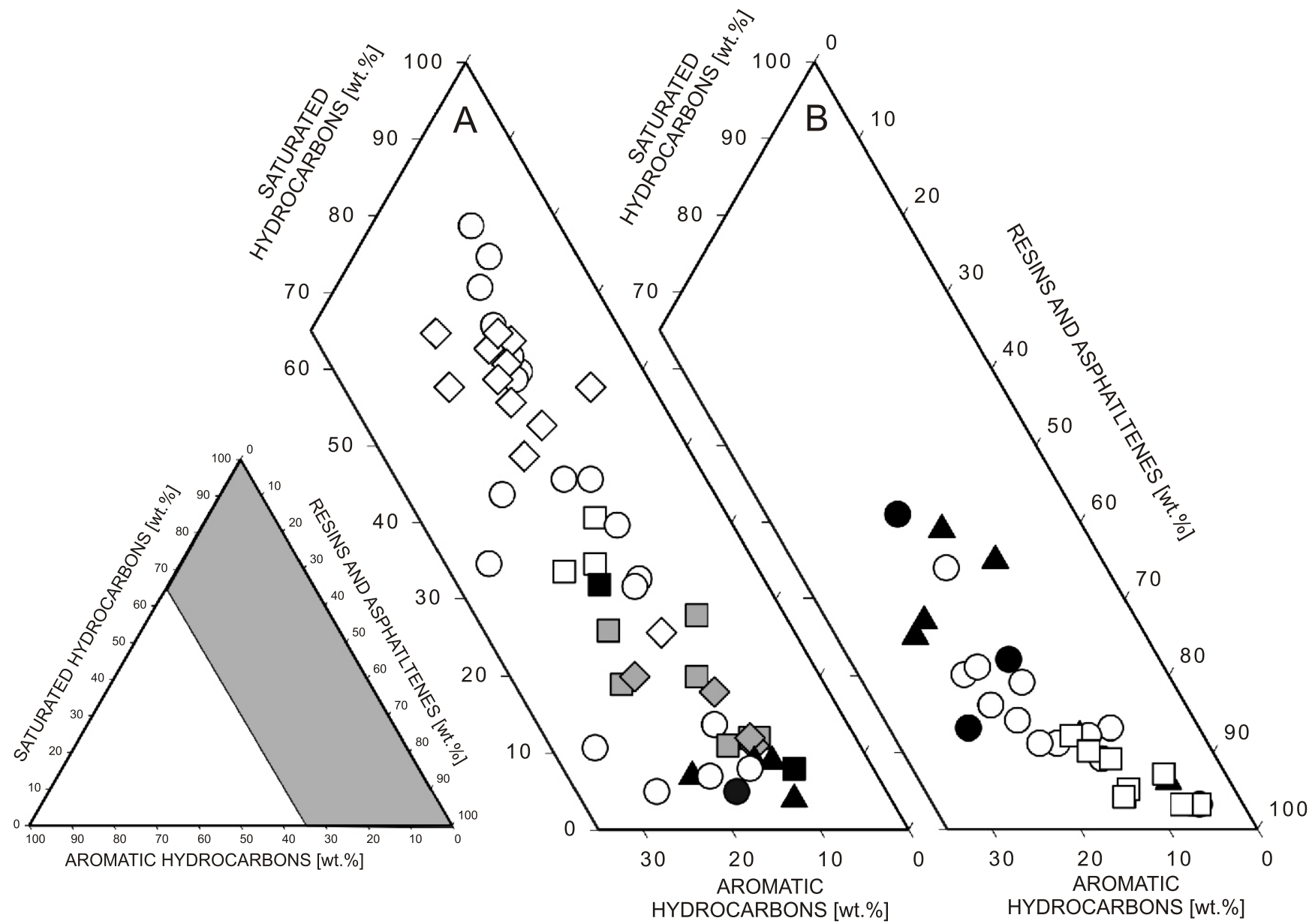

Fig. 9. Ternary diagram of bitumen composition extracted from the Outer Carpathian lithostratigraphic units (A) and Paleozoic-Mesozoic basement (B)

For key to sampled boreholes and names of lithostratigraphic units see Figures 1 and 8

bons. Locally, in the Słopnice-26 borehole and Ubiad exposure, the rocks of the Krosno beds are also impregnated by epigenetic hydrocarbons (Fig. 8A). This is supported by a high (up to 65 wt.\%) content of saturated hydrocarbons in the bitumen (Fig. 9A) and production index (PI) values up to 0.49 (Table 1).

The results of these and previous studies (Kotarba and Koltun, 2006; Wróbel et al., 2016) of pyrolytic (Table 1; Appendix 2 and Fig. 10A), stable carbon isotope (Appendix 2 and Fig. 11A), biomarker (Tables 4 and 5; Figs. 12A and 13) and kerogen elemental composition analyses (Table 5 and Fig. 14) reveal that mixed marine/terrestrial kerogen Type-II/III or III/II occurs in all lithostratigraphic units investigated. Proportions of kerogen mixing are difficult to establish due to a high maturity of the organic matter (Tables 1, 5 and 6; Appendix 2 and Fig. 10A). Pristane/phytane (Pr/Ph) ratio values (Appendix 2) point to normal marine and at times highly oxidizing conditions in the sedimentary environment (Didyk et al., 1978), and the $\mathrm{C}_{27}$ diasteranes/(diasteranes+regular steranes) ratio values suggest a domination of clays in the mineral matrix (Peters et al., 2005). However, these data can be affected by the previously mentioned high level of maturity (ten Haven et al., 1987). Only in the Menilite beds sampled at exposure in Kobielnik is domination of the oil-prone Type-Il kerogen visible. Hydrogen index $(\mathrm{HI})$ values are $>300 \mathrm{mg} \mathrm{HC} / \mathrm{g}$ TOC (Appendix 2 and Fig. 10A). The composition of stable carbon isotopes (Appendix 2 and Fig. 11A) supports the conclusions from Rock-Eval analyses indicating the presence of two facies significantly dif- ferent in $\delta^{13} \mathrm{C}$. The first one, depleted in ${ }^{13} \mathrm{C}$, represents pure Type-Il kerogen and the other one is probably a mixture of Type-II and Type-III kerogens. These differences of facies are apparent in the elemental composition of the kerogen (Table 5 and Fig. 14) suggesting domination of Type-II kerogen. The pristane/phytane ratio values below unity suggest anoxic conditions during deposition of organic matter (Appendix 2) and biomarker ratios, e.g. $\mathrm{C}_{29}$ norhopane $/ 17 \alpha$ hopane and $\mathrm{C}_{35} / \mathrm{C}_{34}$ of homohopanes (Table 4 ) indicate that clays dominate in the mineral matrix. The Menilite beds from the Skrzydlna tectonic window are significantly less mature (initial phase of the oil window) than those sampled from the Dukla Unit occurring in tectonic windows or boreholes beneath the overthrust of the Magura Unit.

Taking into account that highly-matured mixed Type-II/III kerogen is present in the successions investigated (excluding the Menilite beds in the Skrzydlna tectonic window), their initial hydrocarbon potential was much higher. The initial TOC content was calculated after Cornford (1994). The initial TOC content in the Inoceramian beds was similar to the present value due to a significant share of Type-III kerogen (Table 9). Assuming the dominance of Type-Il kerogen in the Rdzawka (Hieroglyphic shales) and Menilite beds and similar proportions of the Type-II and Type-III kerogens in the Krosno beds, the initial TOC $\left(\mathrm{TOC}_{0}\right)$ was estimated at $\sim 0.8 \mathrm{wt} \%$ in the first and last mentioned beds and $\sim 2.0$ wt. $\%$ in the Menilite beds (Table 9 ). 

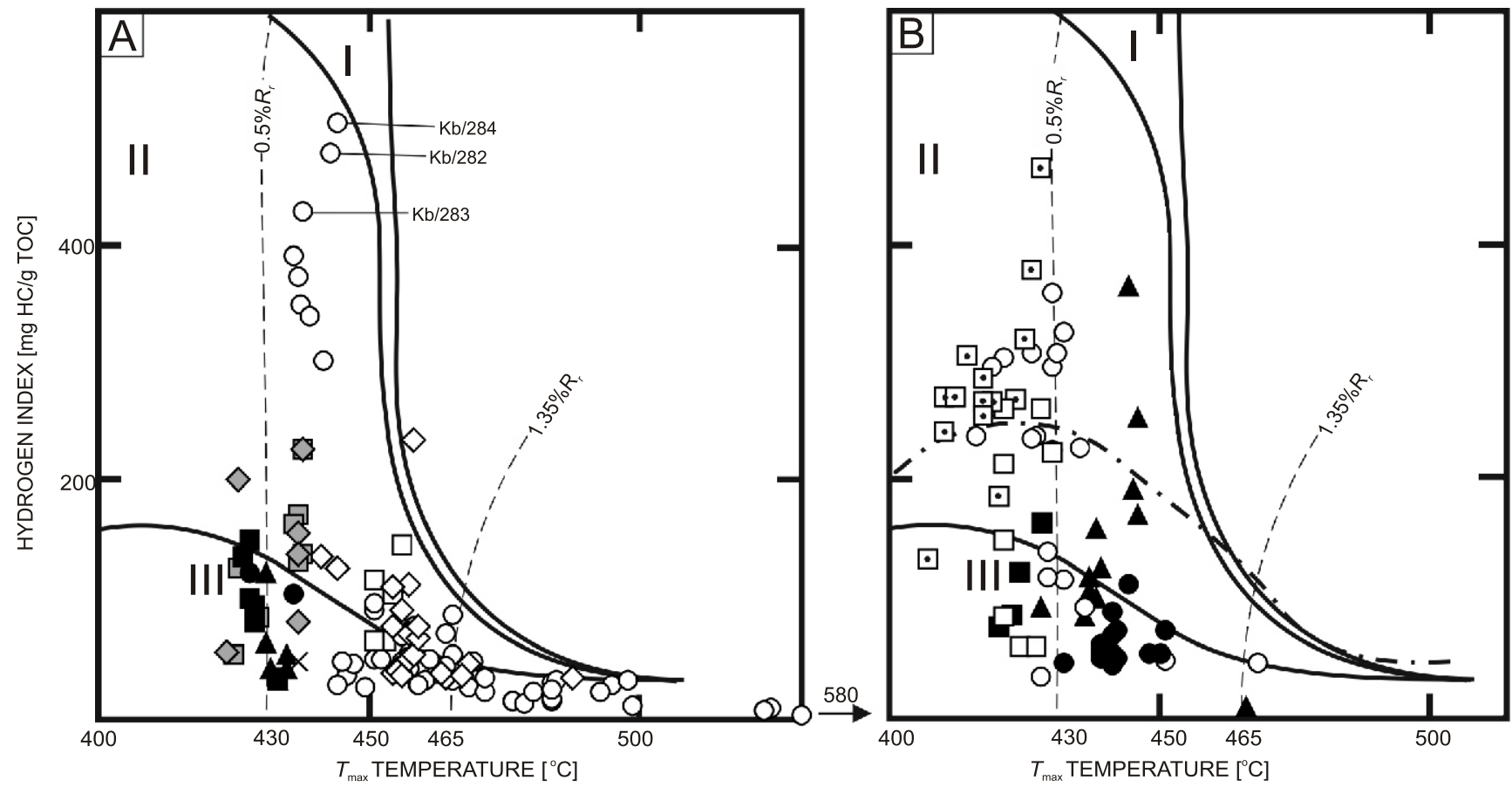

Fig. 10. Hydrogen index versus $T_{\max }$ temperature for the Outer Carpathian lithostratigraphic units (A) and Paleozoic-Mesozoic basement (B)

Maturation paths for kerogens after Espitalié et al. (1985); dashed-dotted line represents maturity path of organic matter concentrated in lenses or seams; for key to sampled boreholes and name of lithostratigraphic units see Figures 1 and 8 ; dotted samples were collected from lignite lenses within Middle Jurassic strata
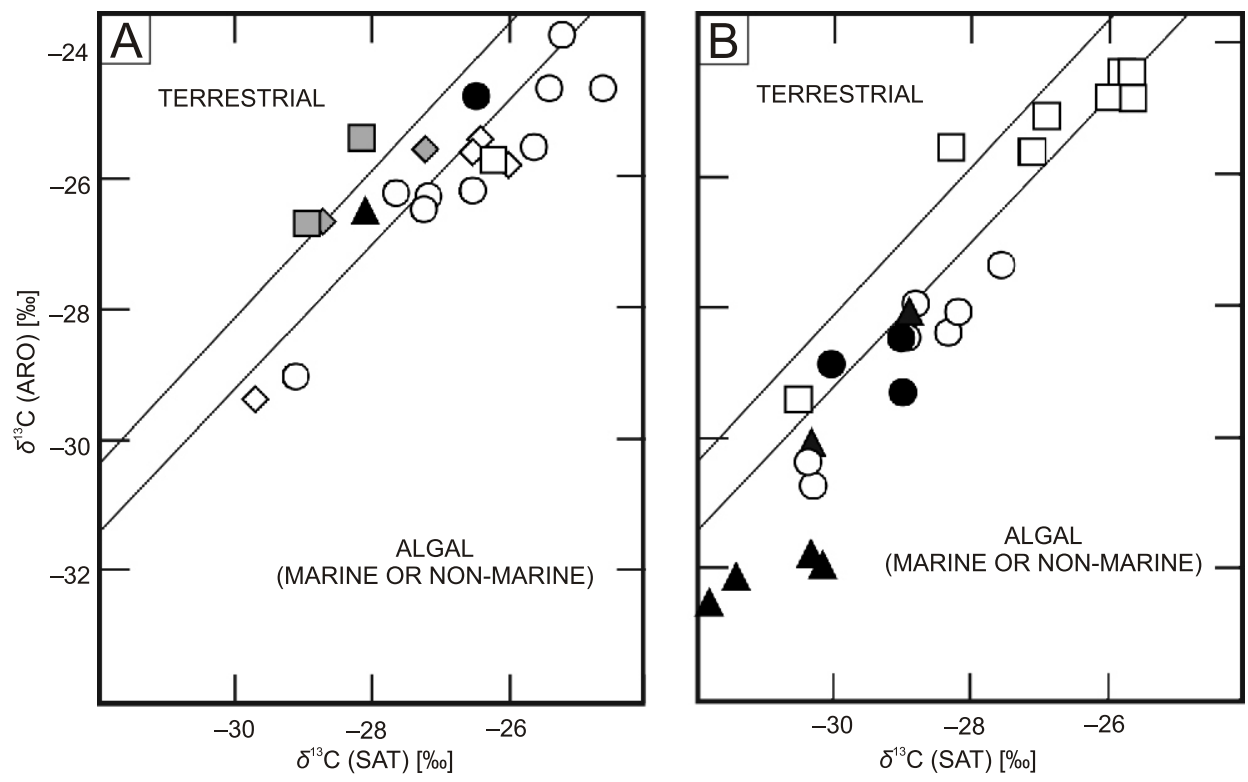

Fig. 11. Genetic characterization of bitumen from the Outer Carpathian lithostratigraphic units (A) and Paleozoic-Mesozoic basement (B) in terms of $\delta^{13} \mathrm{C}$ (aromatic hydrocarbons) and $\delta^{13} \mathrm{C}$ (saturated hydrocarbons)

Categories after Sofer (1984); for key to lithostratigraphic units see Figure 8 


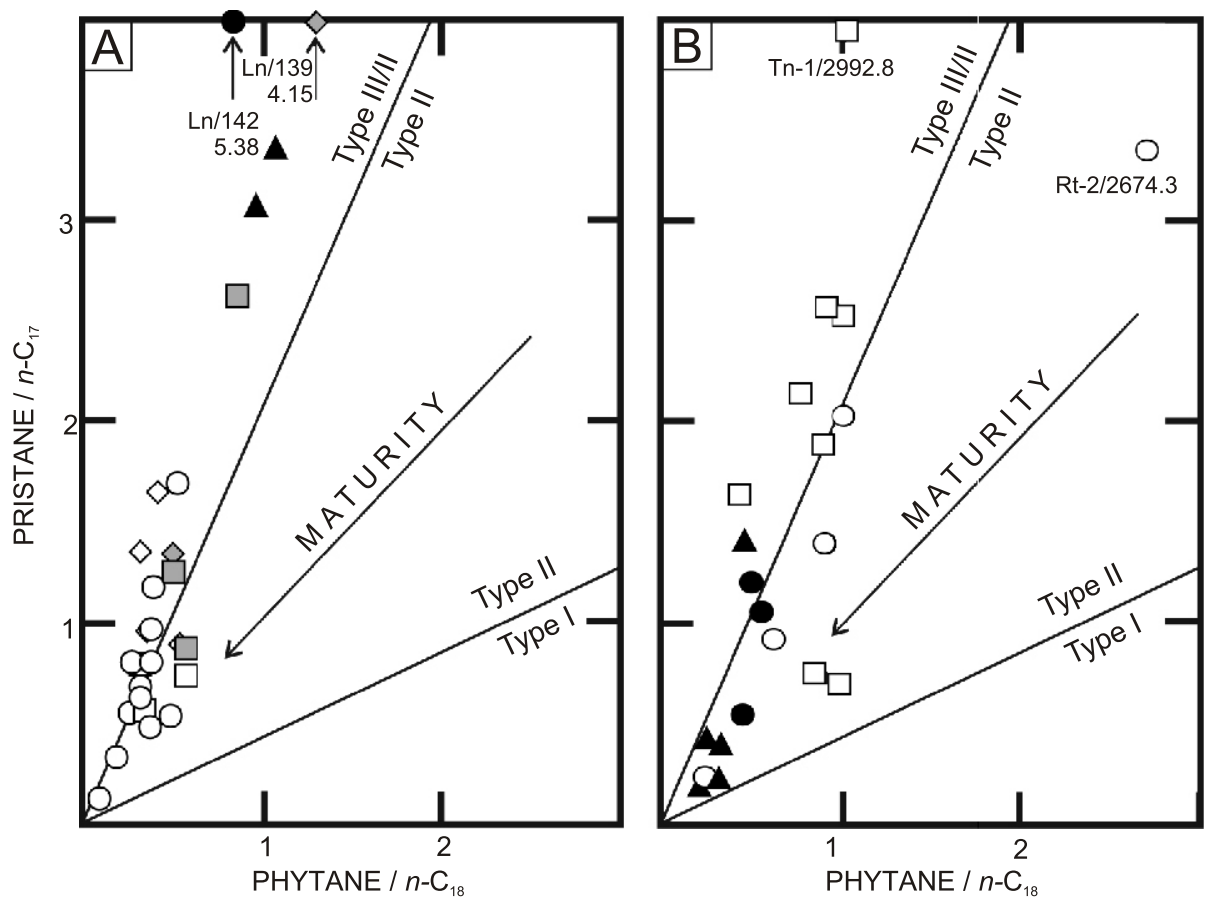

Fig. 12. Genetic characterization of bitumens from the Outer Carpathian lithostratigraphic units $(A)$ and Paleozoic-Mesozoic basement (B) in terms of pristane/ $n \mathrm{C}_{17} \mathrm{H}_{36}$ and phytane/n $\mathrm{C}_{18} \mathrm{H}_{38}$

Categories after Obermajer et al. (1999); for key to samples and name of lithostratigraphic units see Appendix 2 and Figure 8

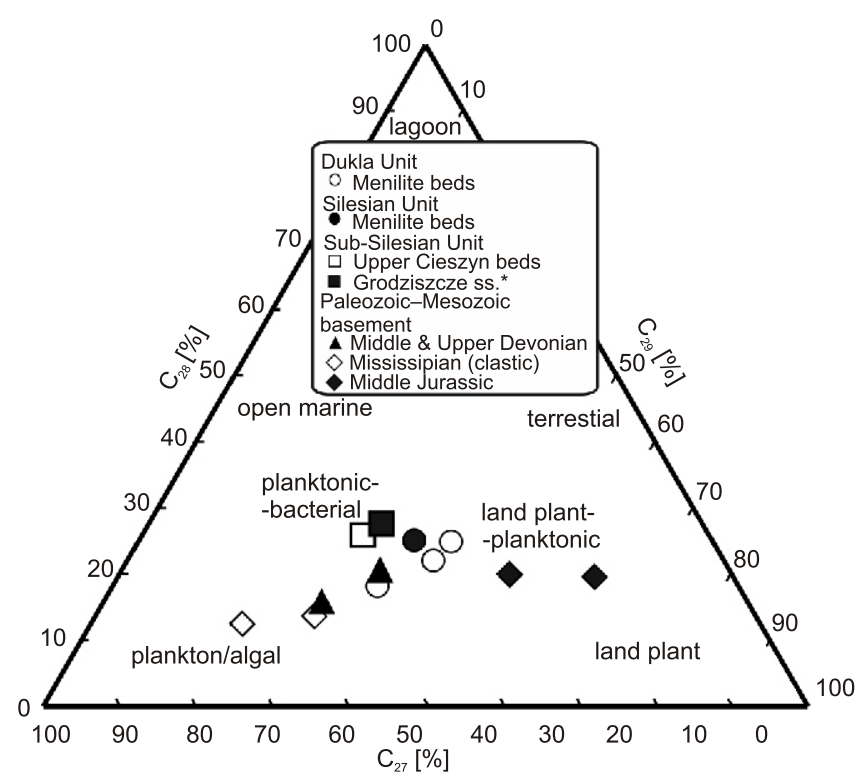

Fig. 13. Tertiary diagram of $20 \mathrm{R}$ regular sterane distribution; genetic fields modified after Peters et al. (2005)

* claystone intercalations within the Grodziszcze sandstones

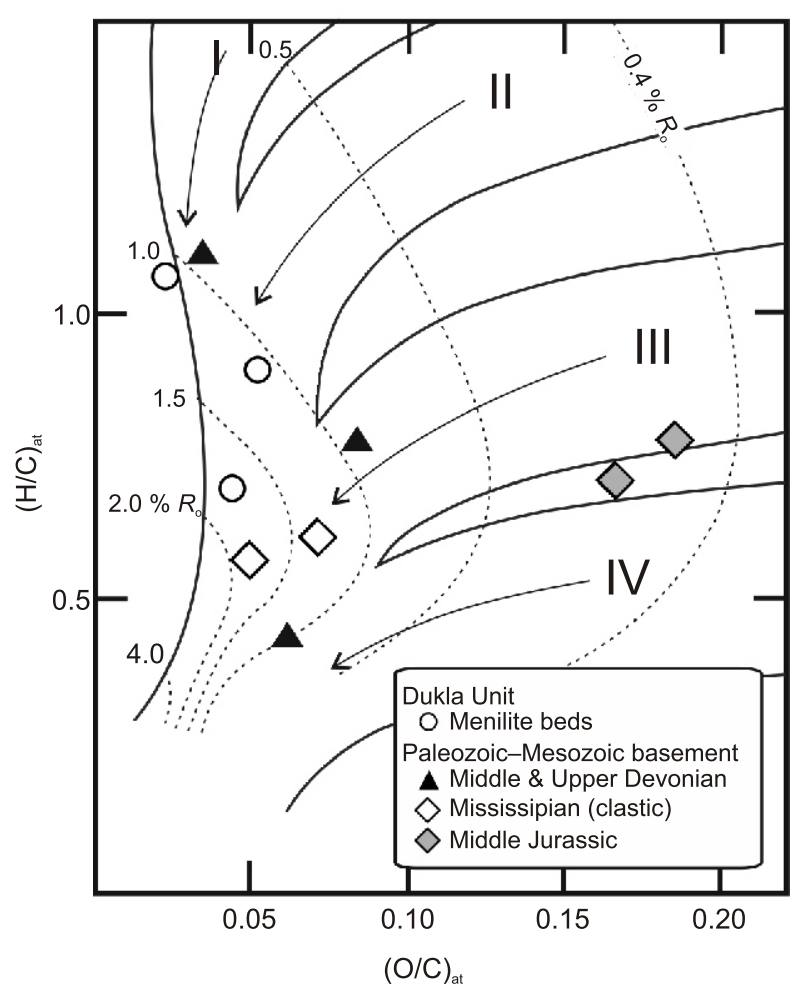

Fig. 14. $(\mathrm{H} / \mathrm{C})_{\text {atomic }}$ versus $(\mathrm{O} / \mathrm{C})_{\text {atomic }}$ for organic matter from Outer Carpathian lithostratigraphic units and Paleozoic-Mesozoic basement

Fields represent natural maturity paths for individual kerogens after Hunt (1996) 
Table 9

Estimated values of original total organic carbon (TOC0) content in investigated lithostratigraphic units of Dukla Unit

\begin{tabular}{|l|c|c|c|c|c|}
\hline \multicolumn{1}{|c|}{ Lithostratigraphy } & Kerogen type & $\begin{array}{c}\text { Estimated proportions of } \\
\text { kerogen types mixing }\end{array}$ & $\begin{array}{c}\text { TOC present } \\
{[\text { wt.\%] }}\end{array}$ & $\begin{array}{c}\text { Mean maturity } \\
\left.\left[\% R_{r}\right]\right)\end{array}$ & $\begin{array}{c}\text { TOC }{ }_{0} \\
{[\mathrm{wt} . \%]}\end{array}$ \\
\hline $\begin{array}{l}\text { Inoceramian beds } \\
\text { (Upper Cretaceous) }\end{array}$ & III/II & $70 / 30$ & 0.4 & 1.2 & 0.4 \\
\hline $\begin{array}{l}\text { Hieroglyphic ss. \& sh. } \\
\text { (E.) (Rdzawka beds) }\end{array}$ & II (II/III) & $80 / 20$ & 0.4 & 1.2 & 0.8 \\
\hline Menilite beds (OI.) & II/III & $70 / 30$ & 0.8 & 1.3 & 2.0 \\
\hline Krosno beds (OI.) & II/III and III/II & $50 / 50$ & 0.5 & 1.3 & 0.8 \\
\hline
\end{tabular}

Kerogen type in parenthesis secondary occurrence; E. - Eocene; Ol. - Oligocene; ss. - sandstones; sh. - shales

The Outer Carpathians - Silesian Unit. The Lgota beds have poor hydrocarbon potential, with low TOC content and $S_{2}$ (Fig. 15A). The extractable hydrocarbons content (Fig. 8A) confirms the poor quality of the Lgota beds as a source rock. Gas-prone kerogen Type-III is immature or early mature (Fig. 10A). The Godula beds are lean in organic matter (Table 2). The hydrocarbon potential of the Istebna beds is also poor, but higher than in the Lgota beds. The TOC content usually ranges from 1 to 2 wt.\% (Figs. 6 and 15A); however, the residual hydrocarbons content does not exceed $1 \mathrm{mg} \mathrm{HC} / \mathrm{g}$ rock (Table 2; Figs. 6 and 15A). The extractable hydrocarbons content makes this formation a fair oil source (Fig. 8A). The results of pyrolytic (Table 2; Figs. 6, 10A and 15A) and biomarker (Appendix 2 and Fig. 12A) analyses show the domination of gas-prone Type-III kerogen. Stable carbon isotope composition (Appendix 2 and Fig. 11A) indicates local admixtures of oil-prone Type-ll kerogen. High, i.e. $>3$, values of pristane/phytane $(\mathrm{Pr} / \mathrm{Ph}$ ) ratio (Appendix 2) suggest a highly oxidative environment during deposition of these strata (Didyk et al., 1978), which is typical of terrestrial organic matter. This observation is supported by the value of the canonical variable $(C V=0.61)$. Organic matter is low-mature (initial stage of the low-temperature thermogenic process; Table 2; Figs. 6 and 10A). The petroleum potential of the Menilite beds is difficult to evaluate due to unrepresentative sampling (2 samples from exposure at Lipnik; Fig. 1), but these two samples reveal the best hydrocarbon potential of all samples collected from the Silesian Unit in the study area (Table 2). The extractable hydrocarbons data (Fig. 8A) support good potential for oil source of this lithostratigraphic unit. Values of hydrogen index $(\mathrm{HI})$ of all samples investigated from the Silesian Unit are $<200 \mathrm{mg} \mathrm{HC} / \mathrm{g}$ TOC suggesting the domination of gas-prone Type-III kerogen (Table 2; Appendix 2; Figs. 6, 10A and 15A). The composition of stable carbon isotopes (Appendix 2 and Fig. 11A) and biomarker indices (Appendix 2; Tables 4 and 5) and their correlation (Figs. 12A and 13) support the conclusions from Rock-Eval analyses. The values of $\mathrm{Pr} / \mathrm{Ph}$ ratio varying from 3.39 to 5.4 (Appendix 2) indicate oxic conditions during deposition of organic matter and $\mathrm{CPI}$ values $>1$ and $C_{35} / C_{34}$ ratio of homohopanes $<1$ suggest a dominance of clays in the mineral matrix. Rock-Eval, biomarker and aromatic hydrocarbon indices (Tables 2, 4 and 5) reveal that the maturity of the strata investigated corresponds with the initial stage of low-temperature thermogenic processes (Tables 2 and 5; Figs. 6 and 10A).

The Outer Carpathians - Sub-Silesian Unit. Although the TOC content in the Upper Cieszyn beds usually exceeds $1 \mathrm{wt} . \%$ and in claystone intercalations within the Grodziszcze sandstones is close to unity, the residual hydrocarbon potential of both units is poor and does not exceed $2.5 \mathrm{mg} \mathrm{HC} / \mathrm{g}$ rock (Table 2; Figs. 6 and 15A). Extractable hydrocarbons are always syngenetic with kerogen and point to the Upper Cieszyn beds as a good oil source and claystone intercalations within the Grodziszcze sandstones as a fair oil source (Fig. 8A). The fraction composition of bitumen is similar in both lithostratigraphic units (Fig. 9A), which indicates the similar genetic type of organic matter. The results of pyrolytic (Table 2; Appendix 2; Figs. 10A and 15A), as well as stable carbon isotopes (Appendix 2; Fig. 11A) and biomarker (Appendix 2; Tables 4 and 5; Figs. $12 \mathrm{~A}$ and 13 ) studies reveal that mixed kerogen Type-III/II (or II/III) with a greater share of the gas-prone Type-III kerogen occurs in the Upper Cieszyn beds. Sofer (1984) suggests canonical variable values $>0.47$ as typical for non-marine organic matter. Therefore values recorded for samples analysed from 0.58 to 2.98 (Appendix 2) show the domination of terrestrial kerogen in both the Upper Cieszyn beds and claystone intercalations within the Grodziszcze sandstones. The organic matter was deposited in sub-oxic conditions as shown by $\mathrm{Pr} / \mathrm{Ph}$ ratios (Appendix 2). The elevated values of homohopane $\mathrm{C}_{35} / \mathrm{C}_{34}$ ratio suggest a dominance of carbonaceous material in the mineral matrix, but values of other ratios (e.g., CPI values $>1$, low values of $\mathrm{C}_{29}$ norhopane/17 $\alpha$ hopane and dibenzothiophene/phenanthrene ratios) do not confirm this thesis (Tables 4 and 5). The presence of gammacerane (Table 4) suggests a stratified water column usually connected with sulphate-reducing conditions (Grice et al., 1998) and values of the steranes/hopanes ratio above unity point to the presence of marine organic matter originated generally from planktonic and/or benthic algae (Moldowan et al., 1985). Rock-Eval $T_{\max }$ values and indices derived from aromatic hydrocarbons show that dispersed organic matter is immature or at the initial stage of the low-temperature thermogenic process (Tables 2 and 5; Appendix 2; Fig. 10A).

The Paleozoic-Mesozoic basement. The geochemical evaluation of the Devonian and Mississippian strata was conducted based on the new results of currently analysed samples as well as on the Rock-Eval, stable carbon isotope and $n$-alkane and isoprenoid distribution analyses published earlier (Kotarba et al., 2004a, b; Więcław et al., 2011; Wróbel et al., 2016).

The Lower Devonian strata in the study area are lean in organic matter (Table 3), although Więcław et al. (2011) reported in the vicinity of Rzeszów levels enriched in mature oil-prone kerogen (TOC up to $2.4 \mathrm{wt} . \%, \mathrm{HI}$ up to $442 \mathrm{mg} \mathrm{HC} / \mathrm{g}$ TOC, $T_{\max }$ up to $448^{\circ} \mathrm{C}$, respectively). The organic carbon content in the Middle and Upper Devonian strata is usually $<0.5 \mathrm{wt} . \%$, but in seven samples the TOC content exceeds $1 \mathrm{wt} \%$ (Fig. 7). The residual hydrocarbon potential is also usually poor, though levels classified as fair or good source rocks were recorded (Table 3; Appendix 2 and Fig. 7). The quantities of extractable hydrocarbons indicate poor, fair or good hydrocarbon potential (Fig. 8B). The Rock-Eval data suggest the presence of oil-prone Type-II kerogen with local admixtures of Type-III 


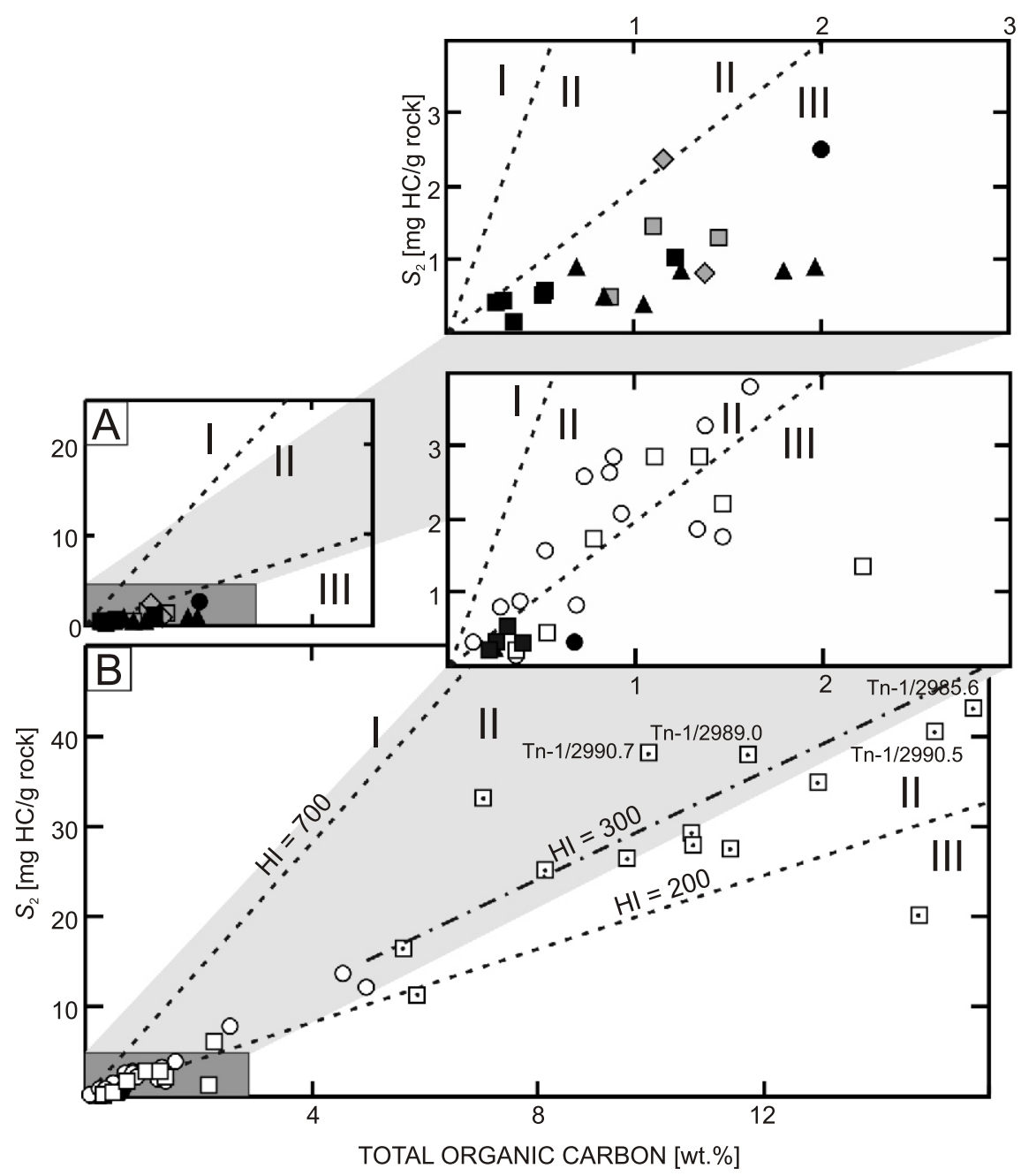

Fig. 15. Kerogen type in terms of residual hydrocarbon potential $\left(S_{2}\right)$ and total organic carbon for the Outer Carpathian lithostratigraphic units (A) and Paleozoic-Mesozoic basement (B)

Categories after Langford and Blanc-Valleron (1990); dashed-dotted line represents upper range of $\mathrm{HI}$ value of organic matter concentrated in lenses or seams (Espitalié et al., 1985); for key to samples and names of lithostratigraphic units see Appendix 2 and Figure 8; dotted samples were collected from lignite lenses within Middle Jurassic strata

kerogen (Fig. 10B). The results of biomarker distribution (Appendix 2; Table 4; Figs. 12B and 13), stable carbon isotope composition (Appendix 2 and Fig. 11B) and kerogen elemental composition (Table 5 and Fig. 14) analyses suggest the presence of Type-II or even Type-I kerogen. The biomarker ratio values (Appendix 2 and Table 4) indicate variable conditions occurring during the deposition of organic matter. The maturity of the strata investigated generally corresponds with the initial stage and peak of the oil window (Tables 3, 5 and 6; Appendix 2; Figs. 7 and 10B). However, the absence of steranes and terpanes in a sample collected from the Grobla-28 borehole (Table 4) and simultaneously high values of aromatic hydrocarbon ratios in this sample (Table 5) suggest almost full realization of hydrocarbon potential of organic matter connected with the overmature zone. Kotarba et al. (2011), Więclaw (2011) and Wróbel et al. (2016) indicated the Middle and Upper Devonian strata as one of the potential source rocks of oils accumulated in the Grobla-Pławowice and Wierzchosławice deposits.

The preliminary characteristics of the Mississippian carbonates were published by Kotarba et al. (2004a, b) and Wróbel et al. (2016). The TOC content as well as residual hydrocarbon potential is changeable (Table 3 and Fig. 15B), but generally low (Fig. 7). The correlation of extractable hydrocarbon amounts and TOC (Fig. 8B) indicates a variable quality of source rock of these strata. The fraction composition of bitumen is variable as well (Fig. 9B). The results of the Rock-Eval pyrolysis analyses reveal the domination of oil-prone Type-II kerogen with local admixtures of Type-III kerogen (Table 3; Figs. 10B and 15B). $n$-Alkane and isoprenoid distribution and stable carbon isotope data (Figs. 11B and 12B) support the previous thesis. The pristane/phytane ratio values are $<1.0$ (Kotarba et al., $2004 a$, b), indicating that reducing conditions occurred during the organic matter deposition. The pyrolytic data (Table 3 and Fig. 10B) and vitrinite reflectance measurements (Kotarba et al., 2004a, b) show a wide range of maturity of the Mississippian carbonates investigated: from immature in the Łąkta- 2 borehole (at $\sim 2650 \mathrm{~m}$ ) to over-mature at the bottom of the Strzelce Wielkie-1 borehole (at $\sim 2900 \mathrm{~m}$ ). The organic matter of most of the samples is immature or early-mature. 
The Mississippian clastic rocks are statistically enriched in TOC relative to carbonates (av. TOC $\sim 1.05$ wt.\%; Table 3), but the residual hydrocarbon potential is lower than in carbonate facies indicating a generally poor petroleum potential of this division (Table 3 and Fig. 7). Gas-prone Type-III kerogen dominates and admixtures of oil-prone Type-II kerogen occurs sporadically which is confirmed by the Rock-Eval (Table 3; Appendix 2 and Fig. 10B) as well as biomarker (Appendix 2; Table 4; Figs. $12 \mathrm{~B}$ and 13), stable carbon isotope (Appendix 2 and Fig. 11B) and elemental kerogen analyses (Table 5 and Fig. 14). Organic matter was deposited in sub-oxic marine clays as indicated by pristane/phytane and dibenzothiophene/phenanthrene ratio values from 1.33 to 2.26 and $<0.1$, respectively (Appendix 2 and Table 5). The results of Rock-Eval pyrolysis and aromatic hydrocarbon ratios indicate a maturity corresponding with the peak of the "oil window" (Tables 3 and 5; Fig. 10B). In addition, the single vitrinite reflectance measurement (Matyasik et al., 2001) supports this observation.

The hydrocarbon potential of the Middle Jurassic strata is variable (Table 3; Figs. 7 and 15B). The TOC and $S_{2}$-richest samples occurred only in the Tarnawa-1 borehole (Fig. 1) in the form of lenses of lignite (Table 3; Figs. 7 and 15B). In other regions these strata are lean in organic carbon. The Rock-Eval pyrolysis data (Table 3; Appendix 2; Figs. 10B and 15B), biomarker distribution (Appendix 2; Table 4; Figs. 12B and 13), stable carbon isotope composition (Appendix 2 and Fig. 11B) and kerogen elemental composition (Table 5 and Fig. 14) indicate that mixed Type-III/II kerogen occurs. Due to the different kinetics of hydrocarbon generation processes in organic matter condensed in seams or lenses, the upper range of $\mathrm{HI}$ value of the gas-prone Type-III kerogen should be raised up to $300 \mathrm{mg}$ HC/g TOC (Fig. 15B) for those samples (Espitalié et al., 1985). The Middle Jurassic strata are generally immature or at the early stage of the low-temperature thermogenic process (Tables 3 and 5; Appendix 2; Fig. 10B).

The results of Rock-Eval analyses of 25 samples from the Upper Jurassic strata taken from Kosakowski et al. (2012a) indicate that these rocks are lean in organic matter with TOC values $<0.5$ wt. $\%$ (usually $<0.1$ wt. $\%$; Table 3 ). Their residual hydrocarbon potential is also poor and does not exceed $0.6 \mathrm{mg}$ $\mathrm{HC} / \mathrm{g}$ rock (Table 3 and Fig. 15B). Gas-prone Type-III kerogen (Figs. 10B and 15B) is immature in the Upper Jurassic strata and therefore these rocks should not be taken into account as potential source rocks in the study area.

\section{NATURAL GAS}

Hydrocarbon gases. Both molecular and isotopic compositions show that the gases analysed derived from the Dukla Unit of the Outer Carpathians are genetically related mainly to thermogenic (thermocatalytic) processes. Only in the Dołuszyce boreholes (De-4 and De-6) was found uneconomic accumulation of natural gas from the Silesian Unit (Kotarba, 1992) attributed to microbial processes (Figs. 4B, C, 16A, 17A and $18 \mathrm{~A}, \mathrm{~B}$ ). In Figure $18 \mathrm{~A}$ and $\mathrm{B}$ the authors fitted vitrinite reflectance curves after Berner and Faber $(1996,1997)$ based on $\delta^{13} \mathrm{C}-28.6 \%$ for the Type-II kerogen (Menilite beds, Kobielnik outcrop, no. 283; Appendix 2) and average $\delta^{13} \mathrm{C}$ $-25.1 \%$ o (three samples) for the Type-III kerogen from the Oligocene Menilite source rocks (Appendix 2). Gas accumulated in the Dukla Unit was mainly generated during high-temperature thermogenic processes ("gas window"; Figs. 16A, 17A and $18 \mathrm{~A}, \mathrm{~B}$ ) at a maturity level of 1.3 to $1.6 \%$ on the vitrinite reflectance scale, assuming the presence of Type-II kerogen (Fig. 18A). However, genetic correlation between hydrocarbon index and $\delta^{13} \mathrm{C}\left(\mathrm{CH}_{4}\right)$ (Fig. 16A) and geochemical analyses of dispersed organic matter revealed the presence of mainly mixed Type-II/III kerogen. In such a case the gas analysed could have been generated at a maturity level of 1.2 to $1.4 \%$ on the vitrinite reflectance scale (Fig. 18A). The microbial component occurs only in the gases from the Dołuszyce uneconomic accumulation (De-4 and De-6 boreholes) in the Silesian Unit (Figs. 4B, C, 16A, 17A and 18A, B; Kotarba, 1992) indicating that the generation process of the thermogenic gaseous hydrocarbons was uniform (Fig. 20A). Methane from the sandstone reservoirs within the Oligocene-Lower Miocene Krosno beds (De-4 borehole) and Upper Cretaceous-Paleocene Istebna beds (De-6 borehole) was generated during microbial carbon dioxide reduction and is isotopically identical to natural gas from the autochthonous Miocene strata of the Carpathian Foredeep (Kotarba, 1998b, 2011). Migration of microbial methane to the traps within the flysch strata from the autochthonous Miocene strata of the Carpathian Foredeep through tectonic contact with the Carpathian overthrust is the most probable, although it is possible that the gas was also generated in situ in the Oligocene-Lower Miocene Krosno beds, which contain molasse deposits resembling the autochthonous Miocene of the Carpathian Foredeep (Kotarba, 1992).

The difference between the stable carbon isotope composition of $n \mathrm{C}_{4} \mathrm{H}_{10}$ and $i \mathrm{C}_{4} \mathrm{H}_{10}$ in natural gas of the SI-3 and SI-24 boreholes (Fig. 20A') is related to different kerogen types of the source rocks. The natural gas accumulated in the Oligocene Cergowa beds (SI-3) is dominated by Type-Il kerogen components, whereas natural gas from the Oligocene-Lower Miocene Krosno beds (SI-24) contains higher admixtures of the Type-III kerogen component (Fig. 5A), the presence of which is confirmed by changes of stable hydrogen and carbon isotope compositions of $\mathrm{CH}_{4}, \mathrm{C}_{2} \mathrm{H}_{6}$ and $\mathrm{C}_{3} \mathrm{H}_{8}$ (Fig. 5C, E).

Both molecular and isotopic compositions show that the gas analysed from the Upper Jurassic carbonate and Upper Cretaceous sandstone reservoirs of the Mesozoic basement (Figs. 16B, 17B, 18C, D, 19B and 20B, B') are mainly genetically related to thermogenic (thermocatalytic) processes of source rock transformation of dispersed organic matter dispersed in the deep basement of the Outer Carpathians within the Middle and Upper Devonian strata and probably within the Middle Jurassic strata at higher depths beneath the Carpathian overthrust. Only in the Brzezowiec field is the gas accumulated in the Upper Cretaceous sandstone trap related to microbial (bacterial) processes (Kotarba and Jawor, 1993). Methane from the Brzezowiec field was generated here during microbial carbon dioxide reduction (Fig. 16B) and is isotopically identical to natural gas from the autochthonous Miocene strata of the Carpathian Foredeep (Kotarba, 2011). This microbial methane migrated from the autochthonous Miocene strata of the Carpathian Foredeep through erosional contact filling the trap within the Cenomanian trap of the Mesozoic basement.

In Figure 18C and D the authors fitted vitrinite reflectance curves after Berner and Faber $(1996,1997)$ based on the average $\delta^{13} \mathrm{C}=-30.8 \%$ (seven samples) for the Type-II kerogen from the Middle and Upper Devonian and Mississippian (clastic) source rocks (Appendix 2) and average $\delta^{13} \mathrm{C}=-23.8 \%$ (2 samples) for the Type-III kerogen from the Middle Jurassic source rocks (Appendix 2). Assuming that the Type-II kerogen (Fig. 18C, D) was responsible for the generation of thermogenic gas accumulated in the Mesozoic basement, thus its maturity was 1.5 to $2.1 \%$ on the vitrinite reflectance scale. Plots of $\delta^{13} \mathrm{C}\left(\mathrm{CH}_{4}\right)$ versus hydrocarbon index $\left(\mathrm{C}_{\mathrm{HC}}\right)$ and $\delta^{13} \mathrm{C}\left(\mathrm{CH}_{4}\right)$ versus $\delta^{2} \mathrm{H}\left(\mathrm{CH}_{4}\right)$ (Figs. 16B and 17B) reveal that the gas from the Grobla and Łąkta (Lk-27 and Le-24) deposits was generated during low-thermogenic processes. Moreover, it accumulated in association with oil (Grobla) and condensate (Łąkta). The 

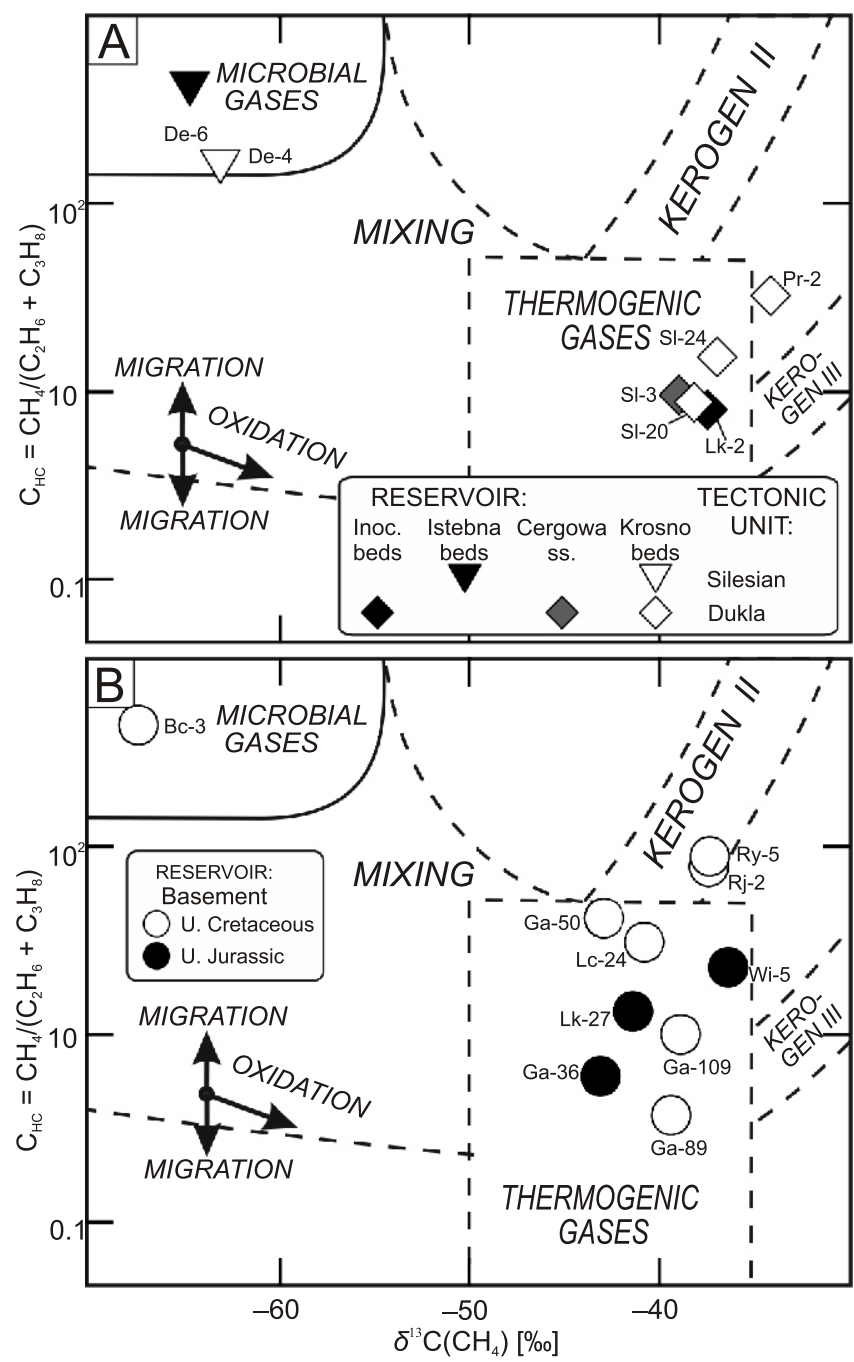

Fig. 16. Genetic characterization of natural gas from the Outer Carpathian lithostratigraphic units $(A)$ and Mesozoic basement $(B)$ using $\delta^{13} \mathrm{C}\left(\mathrm{CH}_{4}\right)$ versus hydrocarbon index $\left(\mathrm{C}_{\mathrm{HC}}\right)$

Compositional fields from Whiticar (1994); for key to sampled boreholes see Figure 1; Outer Carpathians: Inoc. beds - Upper Cretaceous Inoceramian beds; Istebna beds - Upper Cretaceous-Paleocene Istebna beds; Cergowa ss. - Oligocene Cergowa sandstones; Krosno beds - Oligocene-Lower Miocene Krosno beds; Mesozoic basement: U. - Upper

thermogenic gas from the Rylowa, Rajsko and Wierzchosławice deposits were generated during both high-temperature and low-temperature thermogenic processes at a maturity of 1.2 to $1.5 \%$ on the vitrinite reflectance scale assuming the presence of mixed Type-II/III kerogen in the Mississippian and Devonian (Type-III/II kerogen) and Silurian/Ordovician (Type-II kerogen) source rocks (Figs. 5D, F, 16B, 17B, 18C, D and 20B, B'). Normal and insignificant concave isotopic orders $\mathrm{CH}_{4}, \mathrm{C}_{2} \mathrm{H}_{6}, \mathrm{C}_{3} \mathrm{H}_{8}, n \mathrm{C}_{4} \mathrm{H}_{10}$ and $n \mathrm{C}_{5} \mathrm{H}_{12}$ of analysed gases support that the microbial component occurs only in the gas from the Brzezowiec field (Bc-3) and that the generation process of thermogenic gaseous and liquid hydrocarbons was uniform (Fig. 20B, B'). Chung et al. (1988) and Zou et al. (2007) and hydrous pyrolysis experiments reported by Kotarba and Lewan $(2004,2013)$ and Kotarba et al. (2009) suggested that a linear and a concave ("dogleg") trend, characterized by relatively ${ }^{13} \mathrm{C}$-depleted methane compared to ethane, and ethane
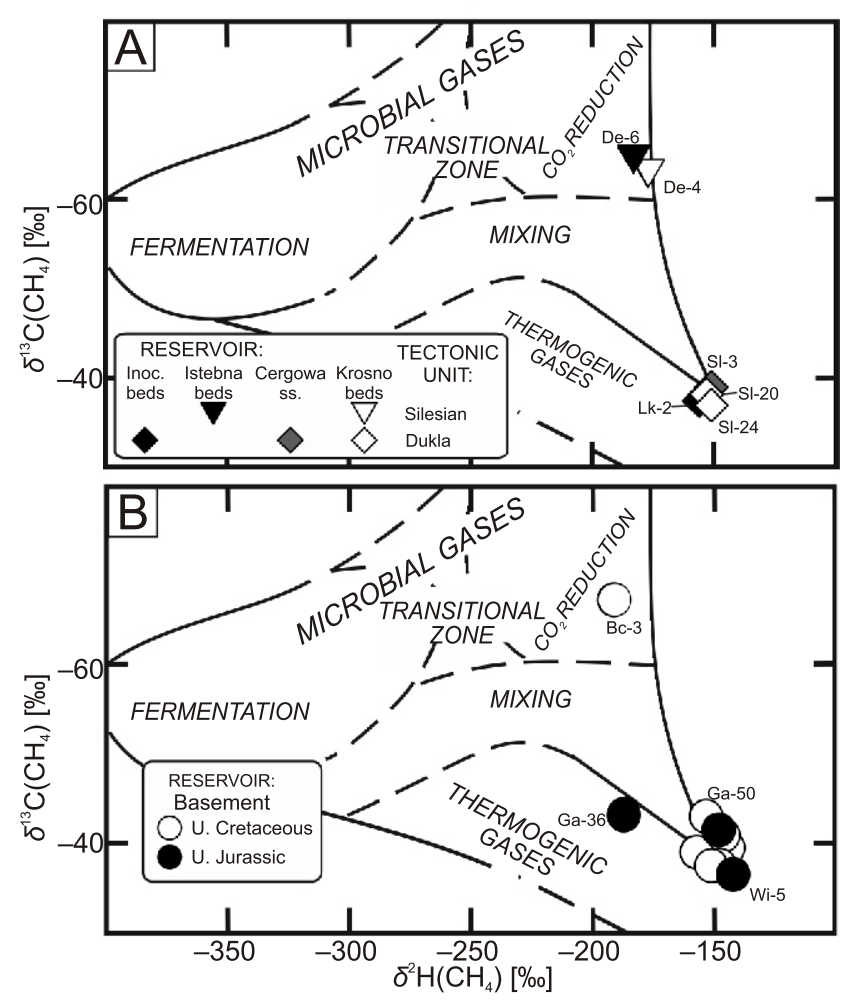

Fig. 17. Genetic characterization of natural gas from the Outer Carpathian lithostratigraphic units (A) and Mesozoic basement (B) using $\delta^{13} \mathrm{C}\left(\mathrm{CH}_{4}\right)$ versus $\delta^{2} \mathrm{H}\left(\mathrm{CH}_{4}\right)$

Explanations as in Figure 16

compared to propane, are indicative of natural gas which was generated from a single source rock and did not undergo post-generation alteration (e.g. biodegradation or oxidation).

Non-hydrocarbon gases - carbon dioxide, hydrogen sulphide and molecular nitrogen. Carbon dioxide occurs in the analysed natural gas both in the Outer Carpathians and the Mesozoic basement in concentrations from 0.0 (Bc-3) to 4.29 vol\% (Wi-5) (Table 7 and Kotarba and Jawor, 1993; Kotarba and Nagao, 2008; Kotarba, 2012) and $\delta^{13} \mathrm{C}\left(\mathrm{CO}_{2}\right)$ vary from -27.9 (Rj-2) to -10.4\%o (Lk-27) (Table 8 and Kotarba and Jawor, 1993; Kotarba and Nagao, 2008; Kotarba, 2012). $\delta^{13} \mathrm{C}\left(\mathrm{CH}_{4}\right)$ versus $\delta^{13} \mathrm{C}\left(\mathrm{CO}_{2}\right)$ correlation indicates that carbon dioxide accumulated both within the Outer Carpathian (Fig. 19A) and Mesozoic basement reservoirs (Fig. 19B) was generated during thermal transformation of organic matter most probably dispersed in the Middle and Upper Devonian strata. In some of the gases from the Grobla, Rajsko and Rylowa deposits, carbon dioxide coincides with hydrogen sulphide (Fig. 21), which can be produced by microbial sulphate reduction (MSR). Hydrogen sulphide occurs in the natural gas analysed in the Grobla, Rajsko and Rylowa deposits in the Upper Jurassic and Upper Cretaceous reservoirs of the Mesozoic basement in concentrations from 0.00 to 0.59 vol\% (Table 7 and Fig. 21). There is a visible correlation between $\mathrm{H}_{2} \mathrm{~S}$ and $\mathrm{CO}_{2}$ concentrations in these three deposits (Table 7 and Fig. 21). This may suggest their common origin, which is most likely related to MSR probably of anhydrite and gypsum intercalations in the Lower and Middle Triassic strata (Tokarski, 1962; Karnkowski, 1977, 1999) occurring within the Mesozoic basement of the study area. In both the Upper Jurassic carbonates and Upper Cretaceous sandstones, gas migrated from the autochthonous Mio- 


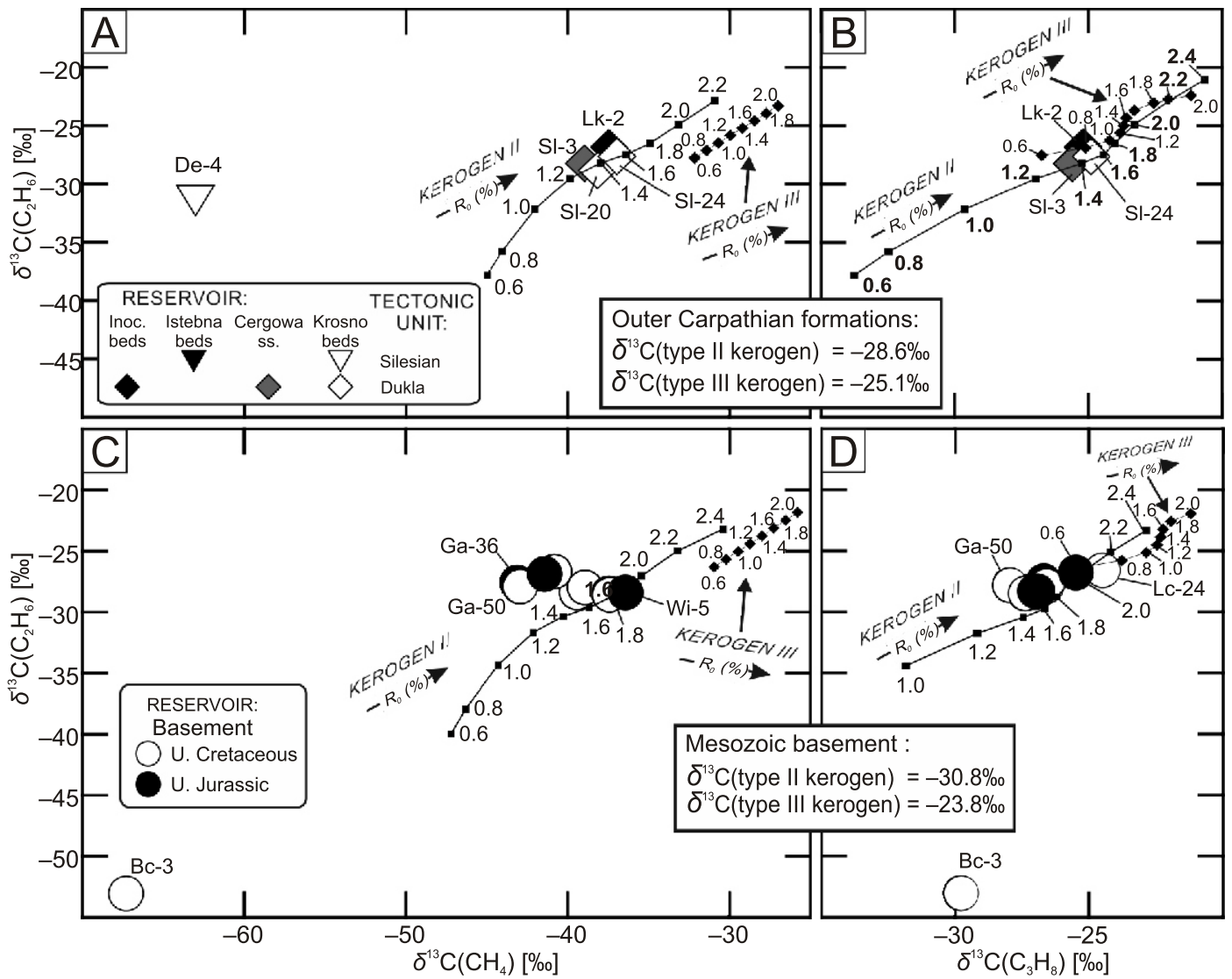

Fig. 18. Genetic characterization of natural gas from the Outer Carpathian lithostratigraphic units ( $A$ and $B$ ) and Mesozoic basement $\left(C\right.$ and $D$ ) using $\delta^{13} \mathrm{C}\left(\mathrm{C}_{2} \mathrm{H}_{6}\right)$ versus $\delta^{13} \mathrm{C}\left(\mathrm{CH}_{4}\right)$ and $\delta^{13} \mathrm{C}\left(\mathrm{C}_{3} \mathrm{H}_{8}\right)$

Vitrinite reflectance curves $\left(R_{r}\right)$ for type II and III kerogens after Berner and Faber (1996); curves were shifted based on $\delta^{13} \mathrm{C}-28.6 \%$ for Type-II kerogen (Menilite beds, Kobielnik outcrop, no. 283) and average $\delta^{13} \mathrm{C}-25.1 \%$ (3 samples) for Type-III kerogen from the Oligocene Menilite source rocks of the Outer Carpathians (Appendix 2), and on the average $\delta^{13} \mathrm{C}=-30.9 \%$ (7 samples) for Type-II kerogen from the Upper Devonian, Middle Devonian and Mississippian (clastic) source rocks and average $\delta^{13} \mathrm{C}=-23.8 \%$ ( 2 samples) for Type-III kerogen from the Middle Jurassic source rocks of the Paleozoic-Mesozoic basement (Appendix 2); for key to sampled boreholes see Figure 1; other explanations as in Figure 16

cene strata of the Carpathian Foredeep at contact fault or erosion slope zones could be observed (Kotarba and Jawor, 1993; Kotarba and Koltun, 2006). The tectonic contact zones between the Upper Jurassic-Upper Cretaceous strata of the Mesozoic basement and the autochthonous Miocene strata of the Carpathian Foredeep occur in the study area, thus the migration of $\mathrm{H}_{2} \mathrm{~S}$ and $\mathrm{CO}_{2}$, generated during MSR within the Middle Badenian anhydrites and gypsum of the Carpathian Foredeep (Ney et al., 1974) to the Upper Jurassic carbonate and Upper Cretaceous sandstone reservoirs of the Mesozoic basement cannot be excluded. Moreover, at least part of hydrogen sulphide could also have been generated during high-temperature thermal transformation of organic matter containing sulphur compounds from the Middle and Upper Devonian strata.

Molecular nitrogen concentration versus $\delta^{15} \mathrm{~N}\left(\mathrm{~N}_{2}\right)$ (Fig. 22) may suggest that it was generated most probably during thermal transformation of organic matter (thermogenic nitrogen) and partly has a component released from illites rich in fixed $\mathrm{NH}_{4}$.

\section{IMPLICATIONS}

Source rocks. The petroleum potential of source rocks within the Outer Carpathians, Carpathian Foredeep, and their
Paleozoic-Mesozoic basement in Poland was earlier widely described by Köster et al. (1998), Kosakowski et al. (2009, 2012a, b), Kotarba et al. (2007, 2013, 2014), Kotarba and Koltun (2006), Więcław et al. (2011, 2012a) and Wróbel et al. (2016). The locations of the most important study areas mentioned above are shown in Figure 2.

The geochemical data of the samples collected from the Oligocene-Lower Miocene Menilite and Krosno beds from the Dukla Unit in the study area are generally consistent with previous investigations (Kotarba and Koltun, 2006) and analyses conducted for these rocks from the eastern parts of this unit in the Polish Outer Carpathians (Kotarba et al., 2007, 2013, 2014). Only the maturity of organic matter in the study area is much higher, indicating the final stage of the oil window beneath the Magura Unit overthrust. The calculated values of initial TOC content for these rocks (Table 9) are generally comparable to the TOC values of source rocks in the Dukla Unit in the eastern parts of the Polish Outer Carpathians (Kotarba et al., 2013, 2014).

Previously published results of geochemical analyses of potential source rocks within the Silesian Unit profile in the eastern part of the Polish Outer Carpathians (Curtis et al., 2004; Kotarba and Koltun, 2006; Lewan et al., 2006; Kotarba et al., 2007, 2013, 2014; Kosakowski et al., 2009) reveal that Menilite beds have the best hydrocarbon potential, containing oil-prone, 

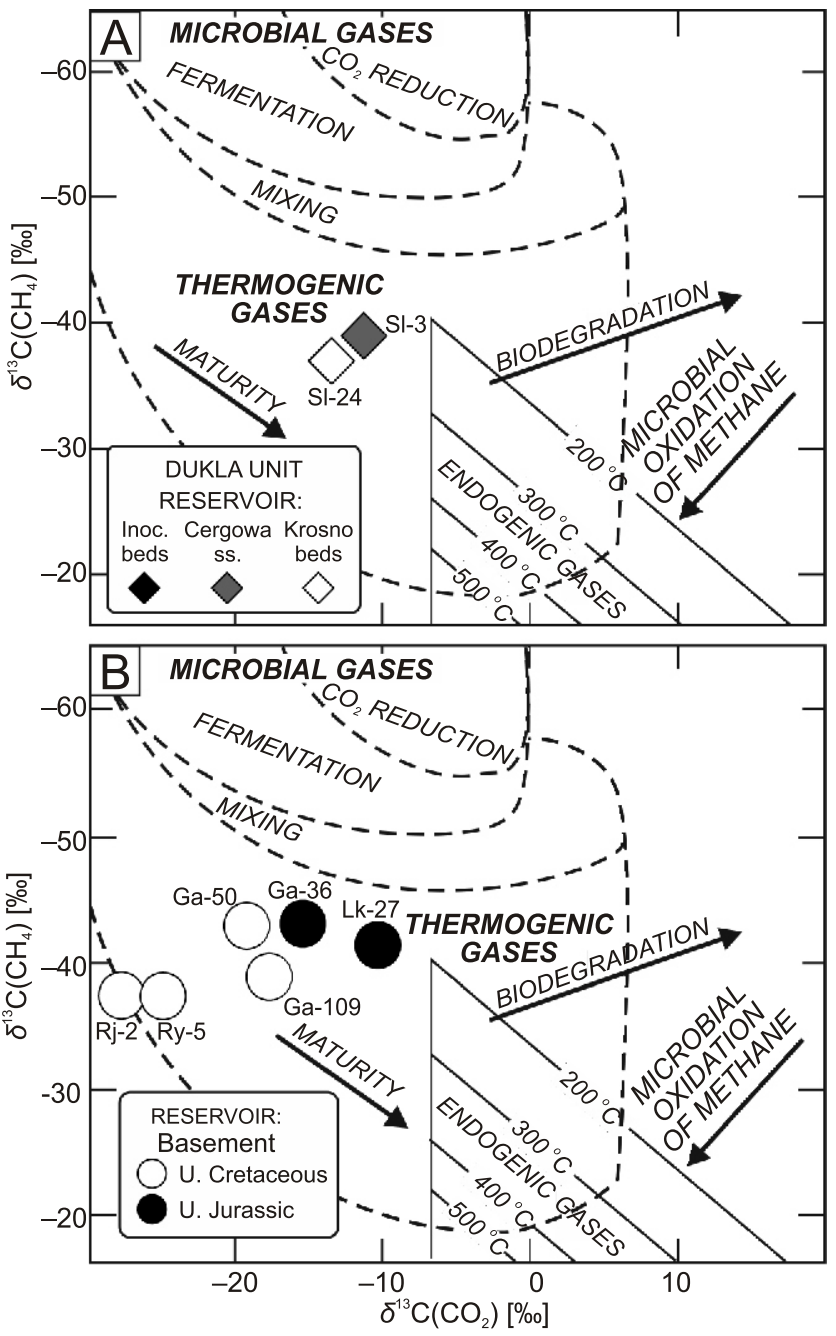

Fig. 19. Genetic characterization of natural gas from the Outer Carpathian lithostratigraphic units $(A)$ and Mesozoic basement (B) using $\delta^{13} \mathrm{C}\left(\mathrm{CH}_{4}\right)$ versus $\delta^{13} \mathrm{C}\left(\mathrm{CO}_{2}\right)$

Compositional fields modified after Gutsalo and Plotnikov (1981) and Kotarba $(2001,2012)$; explanations as in Figure 16

low-sulphur Type-ll kerogen (with local admixtures of gas-prone Type-III kerogen). In the currently analysed samples (Lipnik exposure) the domination of gas-prone Type-III kerogen is visible indicating a change in organic facies. The Menilite beds are considered as a primary source rock in the eastern part of the Polish Outer Carpathians (Curtis et al., 2004; Kotarba et al., 2013, 2014) but in the present study area are not capable of generating thermogenic hydrocarbons. The Cretaceous and Paleocene lithostratigraphic units in the eastern part of Silesian Unit are characterized by a higher hydrocarbon potential than in Gorlice (Kotarba et al., 2013) and the presently analysed areas, and are considered as secondary source rocks for oil and gas accumulations. Due to shallow burial of these rocks in the study area (Fig. 5) resulting in low maturity, their capability of generating thermogenic hydrocarbons is negligible.

The comparison of geochemical data of the Lower Cretaceous lithostratigraphical units from the Sub-Silesian Unit with previously published geochemical characteristics of Lower Cretaceous rocks in the eastern part of this unit (Kosakowski et al., 2009; Kotarba et al., 2014) shows their similarity. Generally, the
Mississippian rocks have poor or moderate hydrocarbon potential with a dominance of immature or early mature gas-prone Type-III kerogen in the whole Polish part of the Sub-Silesian Unit.

The Lower Devonian strata of the basement of the Outer Carpathians and Carpathian Foredeep are lean in organic matter in the study area. However, in the vicinity of Rzeszów some levels of good source-rock parameters were recorded by Więcław et al. (2011). In the Middle and Upper Devonian rocks in other regions of the Polish part of the Carpathian Foredeep, a comparable hydrocarbon potential was recorded by Więcław et al. (2011). The same authors showed that Mississippian carbonates in the vicinity of Rzeszów may be considered as a potential source of hydrocarbons with estimated average of original TOC contents up to 0.8 wt. $\%$. Comparing the petroleum potential of Mississppian clastic rocks in the study area with rocks in another regions of the Paleozoic basement (Więcław et al., 2011) we conclude that hydrocarbon potential of these rocks is similar in all regions.

Middle Jurassic clays in other regions of the Polish part of the Mesozoic basement (in the Pilzno-Rzeszów area) are ranged as moderate source rocks (Kotarba et al., 2003, 2014; Kosakowski et al., 2012a) capable of generating hydrocarbons. Więcław (2011) and Kotarba (2012) considered them as a probable source for many deposits.

Although the Upper Jurassic strata in the study area are lean in organic matter, in the Ukrainian part of the Mesozoic basement (Kosakowski et al., 2012b) and the Polish Lowlands (Więcław, 2016) their hydrocarbon potential is locally very high and the dominant oil-prone Type-II kerogen is capable of petroleum generation. Więcław (2011) and Więcław et al. (2012b) considered them as most probably the source rock of heavy oils accumulated in the Upper Jurassic carbonate deposits in the Polish-Ukrainian border area (Lubaczów, Kokhanivka and Orchovichi deposits).

As a potential source of hydrocarbons in the study area, the so far undrilled Ordovician and Silurian rocks should not be dismissed. The oil-prone Type-Il kerogen present in these strata in the other regions reached a maturity suitable for generation thermogenic hydrocarbons (Więcław et al., 2011, 2012a) and is considered as primary or secondary source for many oils and gases accumulated in the Paleozoic-Mesozoic basement (Kotarba, 2012; Więcław, 2011).

Hydrocarbon gas. Most hydrocarbon gas accumulated in flysch sandstone reservoirs of the Polish Outer Carpathians and in sandstone and carbonate reservoirs of the Paleozoic-Mesozoic basement is of both low-temperature thermogenic ("oil window") and high-temperature thermogenic ("gas window") nature. Moreover, in these structures there locally also occurs microbial and mixing microbial-thermogenic or thermogenic-microbial gas (Kotarba, 1987, 1992, 1998a, b; Kotarba and Koltun, 2006; Kotarba et al., 2007, 2009, 2013, 2014; Kotarba and Nagao, 2008). Molecular and isotopic compositions of natural gas analyses related to geological conditions and the characteristics of source rocks described above allow us to explain its generation, migration and accumulation processes. Below we summarized these gas processes in the study area in comparison with natural gas from selected fields occurring in the Polish Carpathian Province to the east.

Study area. The small Przyszowa oil and gas accumulation occurs in the Oligocene-Lower Miocene Krosno beds of the Dukla Unit (Kotarba, 1987). The hydrocarbon gas was generated during thermogenic processes from the Oligocene Menilite beds (Fig. 4A). Thermogenic hydrocarbon gas from the Leśniówka field in the Dukla Unit was produced from both Oligocene-Lower Miocene Menilite and Eocene Inoceramian 

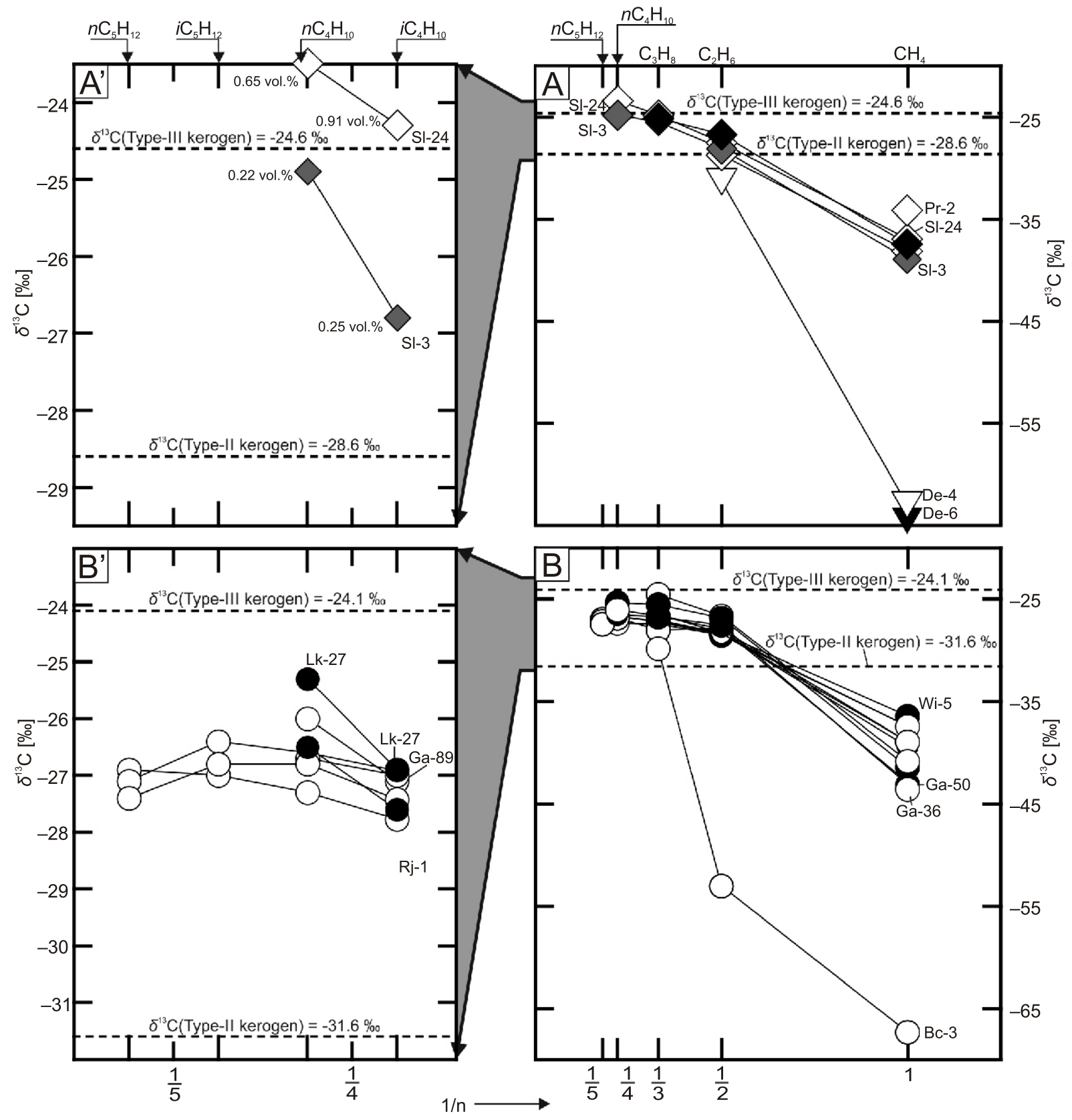

Fig. 20. Stable carbon isotope composition of methane, ethane, propane, $n$-butane and $n$-pentane (A and B), and $i$-butane, $n$-butane, $i$-pentane and $n$-pentane (A' and B') versus the reciprocal of their carbon number for analysed natural gases from the Outer Carpathian lithostratigraphic units (A and A') and Mesozoic basement (B and B')

In diagrams order of ${ }^{13} \mathrm{C}$ values for $\mathrm{CH}_{4}, \mathrm{C}_{2} \mathrm{H}_{6}, \mathrm{C}_{3} \mathrm{H}_{8}, n \mathrm{C}_{4} \mathrm{H}_{10}$ and $n \mathrm{C}_{5} \mathrm{H}_{12}$ is after Chung et al. (1988); for key to sampled boreholes see Figure 1 and for abbreviations of stratigraphy of reservoirs and names of lithostratigraphic units see Figure 15

beds and migrated to the Upper Cretaceous Hieroglyphic beds reservoir (Fig. 5A) while gas from the Słopnice field (Kotarba et al., 2009) was generated from the Oligocene Menilite beds and migrated into the Oligocene Krosno beds (Fig. 5A).

Natural gas of the Dołuszyce uneconomic accumulation in the Oligocene-Lower Miocene Krosno and Upper Cretaceous-Paleocene Istebna beds in the Silesian Unit (Kotarba, 1992) was generated during microbial carbon dioxide reduction and migrated from the autochthonous Miocene strata of the Carpathian Foredeep through tectonic contact with the Carpathian overthrust, subsequently filling the flysch trap (Fig. 4A).
Hydrocarbon gas from the Łąkta-Leszczyny field, accumulated in the Upper Jurassic carbonate reservoir of the Mesozoic basement (Kotarba, 2012) was produced during thermogenic processes and migrated from source rocks including Mississipian and Devonian strata (Table 3 ) and probably also in Middle Jurassic strata occurring at more than $7 \mathrm{~km}$ depth (Fig. 4A). The Grobla, Rajsko, Rylowa and Wierzchosławice oil and gas fields contain similar thermogenic gas (Fig. 5D) in the Upper Jurassic carbonate and the Upper Cretaceous (Cenomanian) sandstone reservoirs (Kotarba, 1992, 2012; Kotarba and Nagao, 2008). This gas was produced during 


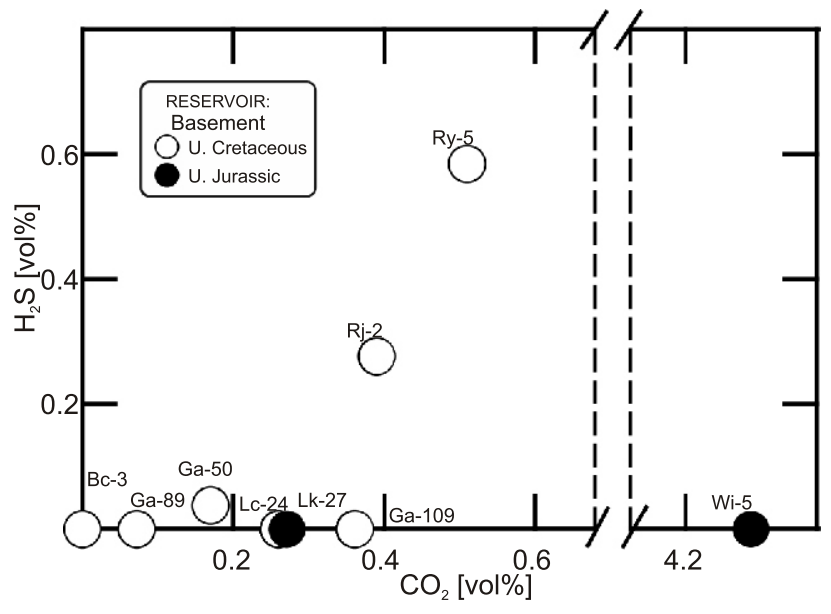

Fig. 21. $\mathrm{H}_{2} \mathrm{~S}$ concentration versus $\mathrm{CO}_{2}$ concentration of natural gas from the Mesozoic basement

For key to sampled boreholes see Figure 1; U. - Upper

thermogenic processes and migrated through the fault zones from source rocks included in Mississipian and Devonian strata (Table 3) and probably also in Lower Paleozoic (Silurian/Ordovician) strata (Fig. 5B).

Methane in the Upper Cretaceous sandstone reservoirs (Mesozoic basement) of the Brzezowiec gas field was generated during microbial carbon dioxide reduction. This microbial methane migrated from the autochthonous Miocene strata of the Carpathian Foredeep through erosional contact, filling a trap within the Cenomanian rocks of the Mesozoic basement (Fig. 23A).

Region to the east of the study area. The interpretation of gas generation, migration and accumulation processes in the study area allowed for better understanding, improvement and reinterpretation of their progress in previously analysed petroleum fields in areas situated to the east (Kotarba, 1998b; Kotarba and Koltun, 2006; Kotarba et al., 2013, 2014).

In the Kobylanka petroleum field two horizons occur, an oil and gas horizon in Oligocene Krosno beds (Gorlice-2 borehole) and a gas horizon in the Upper Paleocene-Eocene Hieroglyphic beds (Kotarba et al., 2009, 2013). Thermogenic gas was generated within the Oligocene Menilite beds and migrated to a trap in the Krosno beds, whereas microbial gas, mainly methane produced within the Oligocene-Lower Miocene Menilite and Miocene Chaotic beds, migrated and filled the trap within the Hieroglyphic beds after forming the Outer Carpathian structure of Miocene age (Fig. 23B).

In the Nosówka oil and gas field reservoir there are Mississipian carbonates (Karnkowski, 1999; Kotarba et al., 2014). Thermogenic gases migrated mainly from the Ordovician, and additionally from the Mississipian source rocks (Fig. 23C). In the Zalesie and Trzebownisko accumulations in the Devonian reservoir (Kotarba et al., 2014) there occurs both thermogenic and microbial gas. The thermogenic component dominates in the Zalesie trap and the microbial one in the Trzebownisko trap. The thermogenic component in the Zalesie field was generated from source rocks in the Ordovician and Silurian strata and additionally from Devonian and Mississippian source rocks, while in the Trzebownisko field it came from mainly Devonian source rocks. The microbial component mi-

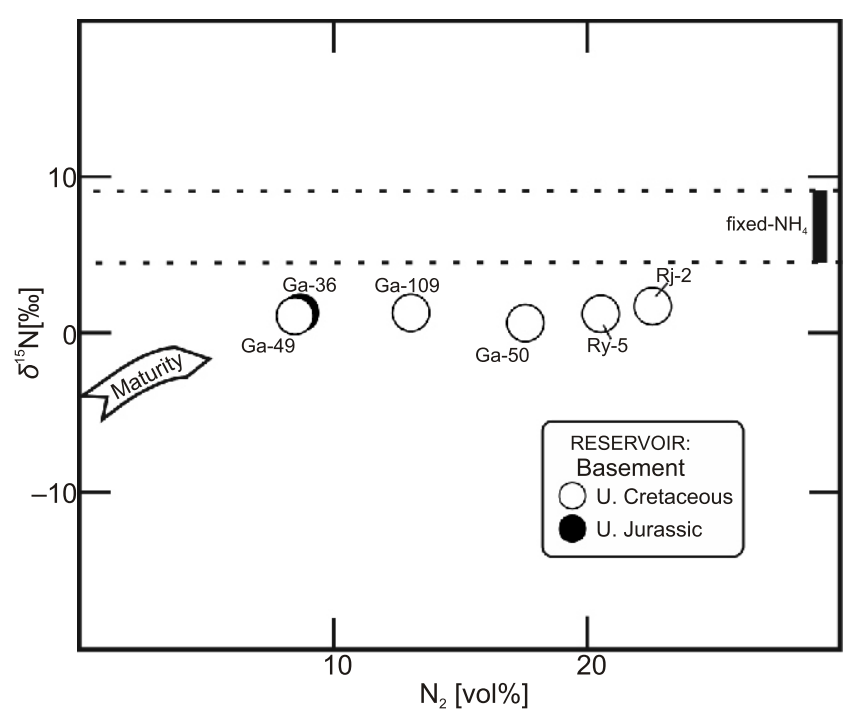

Fig. 22. $\delta^{15} \mathrm{~N}\left(\mathrm{~N}_{2}\right)$ versus molecular nitrogen concentration of natural gas from the Mesozoic basement

Direction of maturity of source rock after Gerling et al. (1997) and Kotarba (1998), and $\delta^{15} \mathrm{~N}$ range of fixed- $\mathrm{NH}_{4}$ in rich illites after Mingram et al. (2005); for key to sampled boreholes see Figure 1; U. - Upper

grated to the Zalesie and Trzebownisko traps through fault zones from the autochthonous Miocene strata of the Carpathian Foredeep (Fig. 23C).

An interesting situation can be encountered in the Lubaczów field near the Polish-Ukrainian border, where biodegraded heavy oil accumulated within the Upper Jurassic carbonate reservoir of the Mesozoic basement of the Carpathian Foredeep (Curtis et al., 2004). One isolated block of this field contains microbial gas (Kotarba, 1998b; Kotarba and Koltun, 2006), which migrated to the Upper Jurassic trap through fault zones from the autochthonous Miocene strata of the Carpathian Foredeep (Fig. 23D).

\section{CONCLUSIONS}

The results of organic geochemical analyses of potential source rocks, molecular and isotopic compositions of natural gases associated or non-associated with oil that accumulated in the Lower Cretaceous-Lower Miocene strata of the Dukla, Silesian and Sub-Silesian units of the Outer Carpathians and Middle and Upper Devonian, Mississippian, Middle and Upper Jurassic and Upper Cretaceous strata of the Paleozoic-Mesozoic basement east of Kraków (southern Poland) indicate that:

1. The Oligocene Menilite beds from the Dukla Unit are characterized by the highest organic carbon content of all lithostratigraphic units in the study area and they are most probably the primary source rock for hydrocarbon accumulations within this unit. Petroleum generation from rocks of other units was negligible.

2. The rock successions of the Sub-Silesian and Silesian units have variable hydrocarbon potential although the dominance of gas-prone Type-III kerogen at a maturity level corre- 

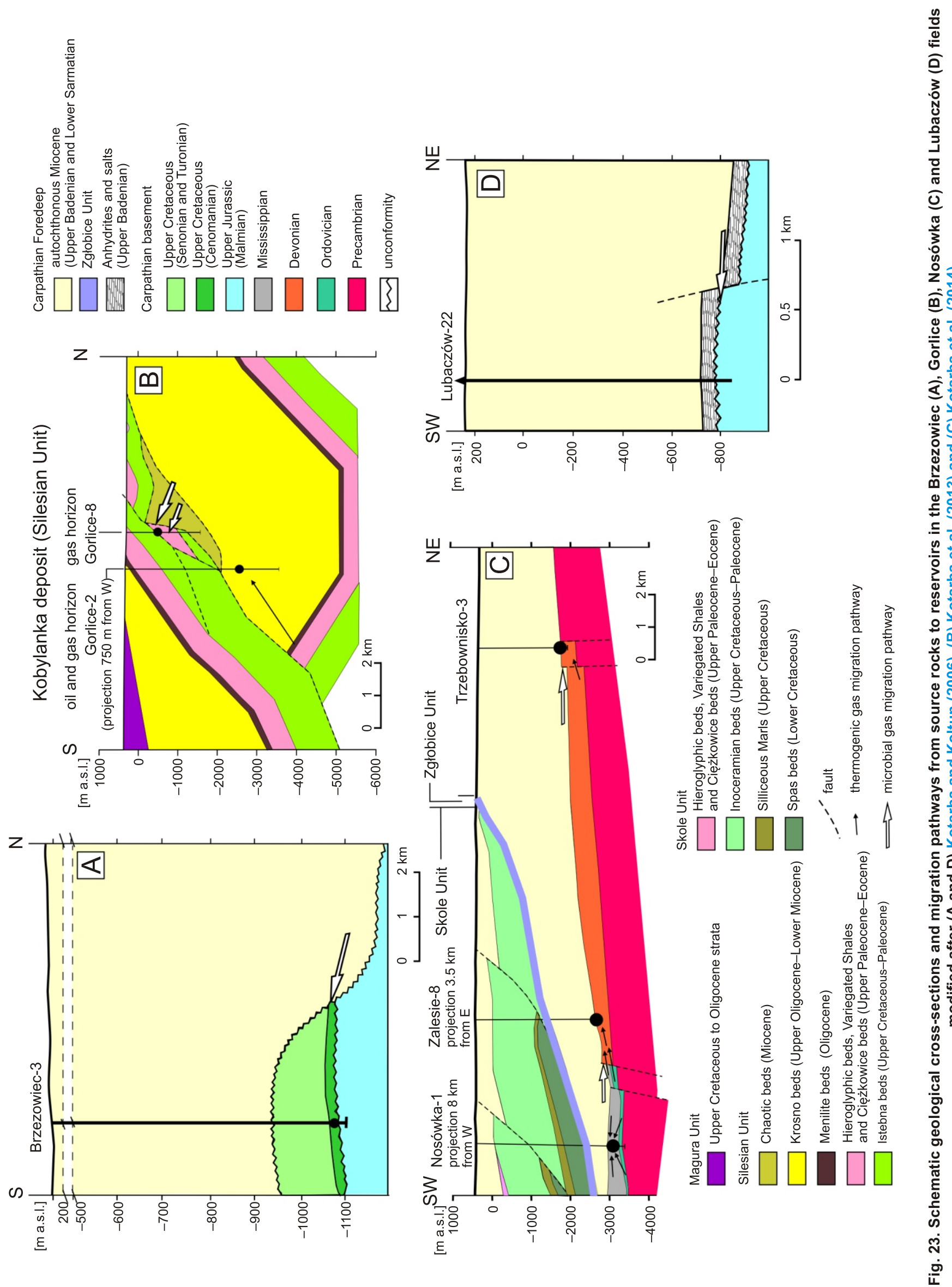
sponding to the initial stage of low-temperature thermogenic processes allows for generation of mainly microbial gases from these rocks.

3. The Middle and Upper Devonian and Mississippian carbonates, due to presence of mature oil-prone Type-Il kerogen, are considered as potential source rocks for petroleum accumulated within the Upper Jurassic and Upper Cretaceous reservoirs. An additional source may be Mississippian clastic rocks. Also, some natural gas and oil from Lower Paleozoic rocks cannot be excluded in the generation processes.

4. Due to immaturity of the organic matter within the Middle Jurassic strata, these rocks can play a role only as a source of microbial gases. The Upper Jurassic strata are poor in organic matter and their role in the hydrocarbon generation process is negligible.

5. Gaseous hydrocarbons accumulated both in the Silesian and Dukla units of the Outer Carpathians and the Paleozoic-Mesozoic basement are genetically related to thermogenic and microbial processes. Gas accumulated in the Dukla Unit was generated during both high-temperature and low-temperature thermogenic processes at a maturity level of 0.8 to $1.4 \%$ on the vitrinite reflectance scale, assuming mixed Type-II/III kerogen of the Menilite beds.

6. The gases analysed from the Upper Cretaceous sandstone and Upper Jurassic carbonate reservoirs in the Mesozoic basement are genetically related to thermogenic processes. These thermogenic gases were generated during both high-temperature and low-temperature thermogenic processes leading to transformation of dispersed organic matter dispersed within the source rocks in the Middle and Upper Devonian strata and probably within the Middle Jurassic strata at greater depths beneath the Carpathian overthrust. Thermogenic hydrocarbon gas accumulated within the Upper Cretaceous sandstone and Upper Jurassic carbonate reservoirs of the Mesozoic basement were generated from the Devonian, Mississippian (carbonate) and Middle Jurassic source rocks.

7. Carbon dioxide occurring in natural gas in the Outer Carpathians was generated during thermogenic transformation of organic matter dispersed within the flysch strata, mainly in the Oligocene Menilite beds.

8. Carbon dioxide occurring in the natural gas in the Mesozoic basement was mainly generated during thermogenic transformation of organic matter dispersed within the Middle and Upper Devonian strata and probably from Middle Jurassic strata at greater depths beneath the Carpathian overthrust. Moreover, carbon dioxide occurring together with hydrogen sulphide probably originated together with $\mathrm{H}_{2} \mathrm{~S}$ during microbial sulphate reduction (MSR) of anhydrite and gypsum intercalations in Lower and Middle Triassic strata of the Mesozoic basement or/and Middle Badenian anhydrite and gypsum of the Carpathian Foredeep.

9. Molecular nitrogen occurring in the natural gas analysed both in the Outer Carpathians and the Mesozoic basement in concentrations from 0.55 to $37.4 \mathrm{vol} \%$ was generated most probably during thermal transformation of organic matter (thermogenic nitrogen) and partly has a component released from illites rich in fixed $\mathrm{NH}_{4}$.

Acknowledgments. The research has been financially supported by the Polish Ministry of Science and Higher Education grant No. 5 T12B 01725 (18.25.140.105) and statutory research project (11.11.140.626) (AGH University of Science and Technology). Analytical work by $\mathrm{H}$. Zych and T. Kowalski from the AGH University of Science and Technology is kindly acknowledged. Dr K. Wójcik from the Polish Geological Institute National Research Institute in Warsaw and two anonymous reviewers provided constructive remarks and comments that greatly improved the discussion of our results.

\section{REFERENCES}

Berner, U., Faber, E., 1996. Empirical carbon isotope/maturity relationships for gases from algal kerogens and terrigenous organic matter, based on dry, open-system pyrolysis. Organic Geochemistry, 24: 947-955.

Berner, U., Faber, E., 1997. Carbon isotope/maturity relationships for gases from algal kerogens and terrigenous organic matter. Geologisches Jahrbuch, D103: 129-145.

Bessereau, G., Roure, F., Kotarba, M., Kuśmierek, J., Strzetelski, W., 1996. Structure and hydrocarbon habitat of the Polish Carpathians. Mémoires du Muséum national d'Historie naturelle, 170: 343-373.

Buła, Z., Habryn, R., 2011. Precambrian and Palaeozoic basement of the Carpathian Foredeep and the adjacent Outer Carpathians (SE Poland and western Ukraine). Annales Societatis Geologorum Poloniae, 81: 221-239.

Chung, H.M., Gormly, J.R., Squires, R.M., 1988. Origin of gaseous hydrocarbons in subsurface environments: theoretical considerations of carbon isotope distribution. Chemical Geology, 71: 91-103.

Coplen, T.B., 2011. Guidelines and recommended terms for expression of stable-isotope-ratio and gas-ratio measurement results. Rapid Communications in Mass Spectrometry, 25: 2538-2560.

Cornford, C., 1994. Mandal-Ekofisk(!) Petroleum System in the Central Graben of the North Sea. AAPG Memoir, 60: 537-571.

Curtis, J.B., Kotarba, M.J., Lewan, M.D., Więcław, D., 2004. Oil/source rock correlations in the Polish Flysch Carpathians and Mesozoic basement and organic facies of the Oligocene Menilite Shales: insights from hydrous pyrolysis experiments. Organic Geochemistry, 35: 1573-1596.
Didyk, B.M., Simoneit, B.R.T., Brassel, S.C., Eglinton, G., 1978. Organic geochemical indicators of palaeoenvironmental conditions of sedimentation. Nature, 272: 216-222.

Dziadzio, P.S., Enfield, M.A., Jankowski, L., Kopciowski, R., Watkinson, M.P., 2001. Field trip guidebook. Carpathian Petroleum Conference - Application of modern exploration methods in a complex petroleum system, 27-30.06.2001, Wysowa: 43.

Dziadzio, P.S., Borys, Z., Kuk, S., Masłowski, E., Probulski, J., Pietrusiak, M., Górka, A., Moryc, J., Baszkiewicz, A., Karnkowski, P., Karnkowski, P.H., Pietrusiak, M., 2006. Hydrocarbon resources of the Polish Outer Carpathians - reservoir parameters, trap types, and selected hydrocarbon fields: a stratigraphic review. AAPG Memoir, 84: 259-291.

Espitalié, J., Deroo, G., Marquis, F., 1985. La pyrolyse Rock Eval et ses applications. Revue IFP, 40-41: 563-579 and 755-784.

Gerling, P., Idiz, E., Everlien, G., Sohns, E., 1997. New aspects on the origin of nitrogen in natural gas in Northern Germany. Geologisches Jahrbuch, D103: 65-84.

Grice, K., Schouten, S., Peters, K.E., Sinninghe Damste, J.S., 1998. Molecular isotopic characterisation of hydrocarbon biomarkers in Palaeocene-Eocene evaporitic, lacustrine source rocks from the Jianghan Basin, China. Organic Geochemistry, 29: $1745-1764$.

Gutsalo, L.K., Plotnikov, A.M., 1981. Carbon isotopic composition in the $\mathrm{CH}_{4}-\mathrm{CO}_{2}$ system as a criterion for the origin of methane and carbon dioxide in Earth natural gases (in Russian). Doklady Akademii Nauk SSSR, 259: 470-473. 
ten Haven, H.L., De Leeuw, J.W., Rullkoetter, J., Sinninghe Damste, J.S., 1987. Restricted utility of the pristane/phytane ratio as a palaeoenvironmental indicator. Nature, 330: 641-643.

ten Haven, H.L., Lafargue, E.. Kotarba, M., 1993. Oil/oil and oil/source rock correlations in the Carpathian Foredeep and Overthrust, south-east Poland. Organic Geochemistry, 20: 935-959.

Hunt, J.M., 1979. Petroleum Geochemistry and Geology. W.H Freeman, San Francisco.

Hunt, J.M., 1996. Petroleum Geochemistry and Geology. W.H. Freeman and Company, New York.

Karnkowski, P., 1977. Underground basement of the Carpathians (in Polish with English summary). Przegląd Geologiczny, 25: 289-297.

Karnkowski, P., 1999. Oil and Gas Deposits in Poland. Geological Society "Geos", Kraków.

Karnkowski, P.H., 2007. Petroleum provinces in Poland (in Polish with English summary). Przegląd Geologiczny, 55: 1061-1067.

Kiersnowski, H., 2001. Permian-Triassic deposits of the Liplas-Tarnawa Basin (in Polish with English summary). Prace Państwowego Instytutu Geologicznego, 174: 84-100.

Koltun, Y.V., 1992. Organic matter in Oligocene Menilite Formation rocks of the Ukrainian Carpathians: palaeoenvironment and geochemical evolution. Organic Geochemistry, 18: 423-430.

Koltun, Y.V., Espitalié, J., Kotarba, M., Roure, F., Ellouz, N., Kosakowski, P., 1998. Petroleum generation in the Ukrainian external Carpathians and the adjacent foreland. Journal of Petroleum Geology, 21: 265-288.

Kosakowski, P., Więcław, D., Kotarba, M.J., 2009. Source rock characteristic of the selected flysch deposits in the transfrontier area of the Polish Outer Carpathians (in Polish with English summary). Geologia AGH, 35: 155-190.

Kosakowski, P., Więcław, D., Kotarba, M.J., Kowalski, A., 2012a. Habitat and hydrocarbon potential of the Mesozoic strata in the Kraków-Rzeszów area (SE Poland). Geological Quarterly, 56 (1): 139-152.

Kosakowski, P., Więcław, D., Kowalski, A., Koltun, Y.V., 2012 b. Assessment of hydrocarbon potential of Jurassic and Cretaceous source rocks in the Tarnogród-Stryi area (SE Poland and W Ukraine). Geologica Carpathica, 63: 319-333

Koszarski, L., 1985. General outline of geology of central part of Carpathian Foredeep and some essential data on the nappes of Polish Outer Carpathians. In: Geology of the Middle Carpathians and the Carpathian Foredeep (ed. L. Koszarski). Guide to excursion 3 of the Carpatho-Balkan Geological Association XIII Congress: 11-39.

Kotarba, M., 1987. Stable carbon isotope composition of natura gases from the central part of the Polish Flysch Carpathians. Bulletin of the Polish Academy of Sciences, Earth Sciences, 35 335-342.

Kotarba, M., 1992. Bacterial gases in Polish part of the Carpathian Foredeep and the Flysch Carpathians: isotopic and geological approach. In: Bacterial Gas (ed. R. Vially): 133-146. Editions Technip, Paris.

Kotarba, M.J., 1998a. Isotopic and pyrolysis studies of organic matter and natural gases from the Flysch Carpathian strata of the Kuźmina-1 deep well. AAPG Annual Meeting Salt Lake City: 4.

Kotarba, M.J., 1998b. Composition and origin gaseous hydrocarbons in the Miocene strata of the Polish part of the Carpathian Foredeep. Przegląd Geologiczny, 46: 751-758.

Kotarba, M.J., 2001. Composition and origin of coalbed gases in the Upper Silesian and Lublin Basins, Poland. Organic Geochemistry, 32: 163-180.

Kotarba, M.J., 2011. Origin of natural gases in the autochthonous Miocene strata of the Polish Carpathian Foredeep. Annales Societatis Geologorum Poloniae, 81: 409-424.

Kotarba, M.J., 2012. Origin of natural gases in the Paleozoic-Mesozoic basement of the Polish Carpathian Foredeep. Geologica Carpathica, 63: 307-318.

Kotarba, M., Jawor, E., 1993. Petroleum generation, migration and accumulation in the Miocene sediments and Paleozoic-Mesozoic basement complex of the Carpathian foredeep between Cracow and Pilzno (Poland). Special Publication of the EAPG, 3: 295-301.

Kotarba, M.J., Koltun, Y.V., 2006. Origin and habitat of hydrocarbons of the Polish and Ukrainian parts of the Carpathian Province. AAPG Memoir, 84: 395-443.

Kotarba, M.J., Lewan, M.D., 2004. Characterizing thermogenic coalbed gas from Polish coals of different ranks by hydrous pyrolysis. Organic Geochemistry, 35: 615-646.

Kotarba, M.J., Lewan, M.D., 2013. Sources of natural gases in Middle Cambrian reservoirs in Polish and Lithuanian Baltic Basin as determined by stable isotopes and hydrous pyrolysis of Lower Palaeozoic source rocks. Chemical Geology, 345: 62-76.

Kotarba, M.J., Nagao, K., 2008. Composition and origin of natural gases accumulated in the Polish and Ukrainian parts of the Carpathian region: Gaseous hydrocarbons, noble gases, carbon dioxide and nitrogen. Chemical Geology, 255: 426-438.

Kotarba, M.J., Więcław, D., Kosakowski, P., Zacharski, J., Kowalski, A., 2003. Evaluation of source rock and petroleum potential of Middle Jurassic strata in the south-eastern part of Poland (in Polish with English summary). Przegląd Geologiczny, 51:1031-1040.

Kotarba, M.J., Więcław, D., Kosakowski, P., Kowalski, A., 2004a Geochemical characteristics of organic matter within Carboniferous strata in the southern part of the Upper Silesian block (in Polish with English abstract). In: Possibilities of the hydrocarbon generation in the Carboniferous rocks of the southern parts of the Upper Silesian and Małopolska blocks (ed. M.J. Kotarba): 49-70. Wydawnictwo Towarzystwo Badania Przemian Środowiska "Geosfera".

Kotarba, M.J., Więcław, D., Kosakowski, P., Kowalski, A., 2004b. Geochemical characteristics of organic matter within Carboniferous strata in the southern part of the Małopolska block (in Polish with English abstract). In: Possibilities of the hydrocarbon generation in the Carboniferous rocks of the southern parts of the Upper Silesian and Małopolska blocks (ed. M.J. Kotarba): 71-86. Wydawnictwo Towarzystwo Badania Przemian Środowiska "Geosfera".

Kotarba, M.J., Więcław, D., Koltun, Y.V., Marynowski, L., Kuśmierek, J., Dudok, I.V., 2007. Organic geochemical study and genetic correlation of natural gas, oil and Menilite source rocks in the area between San and Stryi rivers (Polish and Ukrainian Carpathians). Organic Geochemistry, 38: 1431-1456.

Kotarba, M.J., Curtis, J.B., Lewan, M.D., 2009. Comparison of natural gases accumulated in Oligocene strata with hydrous pyrolysis from Menilite Shales of the Polish Outer Carpathians. Organic Geochemistry, 40: 769-783.

Kotarba, M.J., Więcław, D., Kosakowski, P., Wróbel, M., Matyszkiewicz, J., Buła, Z., Krajewski, M., Koltun, Y.V., Tarkowski, J., 2011. Petroleum systems in the Palaeozoic-Mesozoic basement of the Polish and Ukrainian Carpathian Foredeep. Annales Societatis Geologorum Poloniae, 81: 487-522.

Kotarba, M.J., Więcław, D., Dziadzio, P., Kowalski, A., Bilkiewicz, E., Kosakowski, P., 2013. Organic geochemical study of source rocks and natural gas and their genetic correlation in the central part of the Polish Outer Carpathians. Marine and Petroleum Geology, 45: 106-120.

Kotarba, M.J., Więcław, D., Dziadzio, P., Kowalski, A., Kosakowski, P., Bilkiewicz, E., 2014. Organic geochemical study of source rocks and natural gas and their genetic correlation in the eastern part of the Polish Outer Carpathians and Palaeozoic-Mesozoic basement. Marine and Petroleum Geology, 56: 97-122.

Köster, J., Kotarba, M., Lafargue, E., Kosakowski, P., 1998. Source rock habitat and hydrocarbon potential of Oligocene Menilite Formation (Flysch Carpathians, Southeast Poland): an organic geochemical and isotope approach. Organic Geochemistry, 29: 543-558.

Kruge, M.A., Mastalerz, M., Solecki, A., Stankiewicz, B.A., 1996. Organic geochemistry and petrology of oil source rocks, Carpathian Overthrust region, southeastern Poland - implications for petroleum generation. Organic Geochemistry, 24: 897-912. 
Książkiewicz, M., 1977. Tektonika Karpat (in Polish). In: Geology of Poland (ed. W. Pożaryski), 4 (Tectonics): 476-620. Wyd. Geol. Warszawa.

Langford, F.F., Blanc-Valleron, M.M., 1990. Interpreting Rock-Eval pyrolysis data using graphs of pyrolizable hydrocarbons vs. total organic carbon. AAPG Bulletin, 74: 799-804.

Leenheer, M.J., 1984. Mississippian Bakken and equivalent formations as source rocks in the Western Canadian Basin. Organic Geochemistry, 6: 521-532.

Lewan, M.D., 1980. Geochemistry of Vanadium and Nickel in Organic Matter of Sedimentary Rocks. Ph.D. thesis, University of Cincinnati.

Lewan, M.D., Kotarba, M.J., Curtis, J.B., Więcław, D., Kosakowski, P., 2006. Oil generation kinetics for organic facies with Type-II and -IIS kerogen in the Menilite Shales of the Polish Carpathians. Geochimica et Cosmochimica Acta, 70: 3351-3368.

Matyasik, I., Steczko, A., Mastalerz, M., Brassell, S.C., 2001. Petrographic and geochemical characterization of source rock variability in the Carpathian region of Poland: implication for oil generation. Abstracts of Eighteenth Annual Meeting of the Society for Organic Petrology, Houston, Texas, 18: 78-83.

Mingram, B., Hoth, P., Lüders, V., Harlov, D., 2005. The significance of fixed ammonium in Palaeozoic sediments for the generation of nitrogen-rich natural gases in the North German Basin. International Journal of Earth Sciences, 94: 1010-1022.

Moldowan, J.M., Seifert, W.K., Gallegos, E.J., 1985. Relationship between petroleum composition and depositional environment of petroleum source rocks. AAPG Bulletin, 69: 1255-1268.

Moryc, W., 2006a. Geological structure of Miocene substratum in Kraków-Pilzno region. Part 1. The Precambrian and Palaeozoic (without Permian) (in Polish with English summary). Nafta-Gaz, 5: $197-216$

Moryc, W., 2006b. Geological structure of Miocene substratum in Kraków-Pilzno region. Part 2. The Permian and Mesozoic period (in Polish with English summary). Nafta-Gaz, 6: 263-282.

Moryc, W., 2014. The Permian and Triassic of the Polish Carpathian Foreland (in Polish with English summary). Biuletyn Państwowego Instytutu Geologicznego, 457: 43-68.

Ney, R., Burzewski, W., Bachleda, T., Górecki, W., Jakóbczak, K., Słupczyński, K., 1974. Outline of paleogeography and evolution of lithology and facies of Miocene layers of the Carpathian Foredeep (in Polish with English summary). Prace Geologiczne, 82: 1-65.

Obermajer, M., Fowler, M.G., Snowdon, L.R., 1999. Depositional environment and oil generation in Ordovician source rocks from southwestern Ontario, Canada: organic geochemical and petrological approach. AAPG Bulletin, 83: 1426-1453.

Oszczypko, N., 1997. The Early-Middle Miocene Carpathian peripheral foreland basin (Western Carpathians, Poland). Przegląd Geologiczny, 45: 1054-1063.

Oszczypko, N., 2006. Position of the Polish Outer Carpathians in the Alpine Arc and their stages of development (in Polish with English abstract). In: Paleotectonic Evolution of the Outer Carpathian and Pieniny Klippen Belt Basins (eds. N. Oszczypko, A. Uchman and E. Malata): 9-18. Instytut Nauk Geologicznych Uniwersytetu Jagiellońskiego, Kraków.

Peters, K.E., Walters, O.C., Moldowan, J.M., 2005. The Biomarker Guide, 2nd edition. Cambridge University Press, Cambridge.

Sofer, Z., 1984. Stable carbon isotope compositions of crude oils: application to source depositional environments and petroleum alteration. AAPG Bulletin, 68: 31-49.
Starzec, K., Schnabel, W., Waśkowska, A. Golonka, J., Machowski, G., Stefaniuk, M., 2016. Mélange deposits in the Skrzydlna and Wiśniowa tectonic windows (Outer Carpathians) - preliminary results. 10th ESSEVECA Conference, Bratislava, Abstract Book: 99-101.

Ślączka, A., 1971. Geology of Dukla Unit (in Polish with English summary). Prace Instytutu Geologicznego, 63: 1-97.

Ślączka, A., 1996. Oil and gas in Northern Carpathians. EAGE Special Publications, 5: 187-195.

Ślączka, A., Kaminski, M.A., 1998. A Guidebook to Excursions in the Polish Flysch Carpathians. Field Trips for Geoscientists. Grzybowski Foundation Special Publications, 6: 1-173.

Taylor, G.H., Teichmüller, M., Davis, A., Diessel, C.F.K., Littke, R., Robert, P., 1998. Organic Petrology. Gebrüder Borntraeger, Berlin, Stuttgart.

Tokarski, A., 1962. Le structure de Niwiska (in Polish with French abstract). Prace Geologiczne, 13: 1-60.

Waśkowska, A., Starzec, K., Golonka, J., Machowski, G., 2016. The biostratigraphy of the Skrzydlna olistostrome deposits (Outer Polish Carpathians) - preliminary results. 17th Czech-Slovak-Polish Palaeontological Conference, Kraków Abstract Volume: 95.

Whiticar, M.J., 1994. Correlation of natural gases with their sources. AAPG Memoir, 60: 261-283.

Więcław, D., 2002. Geneza oligoceńskiej ropy naftowej polskich Karpat fliszowych - siarka organiczna w kerogenie warstw menilitowych a kinetyka procesu generowania węglowodorów (in Polish). Ph.D. thesis, AGH University of Science and Technology, Kraków.

Więcław, D., 2011. Origin of liquid hydrocarbons accumulated in the Miocene strata of the Polish Carpathian Foredeep and its Paleozoic-Mesozoic basement. Annales Societatis Geologorum Poloniae, 81: 443-458.

Więcław, D., 2016. Habitat and hydrocarbon potential of the Kimmeridgian strata in the central part of the Polish Lowlands. Geological Quarterly, 60 (1): 192-210.

Więcław, D., Kotarba, M.J., Kowalski, A., Kosakowski, P., 2011. Habitat and hydrocarbon potential of the Palaeozoic source rocks in the Kraków-Rzeszów area (SE Poland). Annales Societatis Geologorum Poloniae, 81: 375-394.

Więcław, D., Kosakowski, P., Kotarba, M.J., Koltun, Y.V., Kowalski, A., 2012a. Assessment of hydrocarbon potential of the Lower Palaeozoic strata in the Tarnogród-Stryi area (SE Poland and western Ukraine). Annales Societatis Geologorum Poloniae, 82: 65-80.

Więcław, D., Kotarba, M.J., Kowalski, A., Koltun, Y.V., 2012b. Origin and maturity of oils in the Ukrainian Carpathians and their Mesozoic basement. Geological Quarterly, 56 (1): 158-168.

Wróbel, M., Kosakowski, P., Więcław, D., 2016. Petroleum processes in the Palaeozoic-Mesozoic strata of the Grobla-Limanowa area (basement of the Polish Carpathians). Geology, Geophysics and Environment, 42: 185-206.

Zou, Y.-R., Cai, Y., Zhang, Ch., Zhang, X., Peng, P., 2007. Variations of natural gas carbon isotope-type curves and their interpretation - a case study. Organic Geochemistry, 38: 1398-1415.

Żelaźniewicz, A., Aleksandrowski, P., Buła, Z., Karnkowski, P.H., Konon, A., Oszczypko, N., Ślączka, A., Żaba, J., Żytko, K., 2011. Regionalizacja tektoniczna Polski (in Polish). Komitet Nauk Geologicznych, Wrocław. 